\title{
Hydraulic Characterization of Overpressured Tuffs in Central Yucca Flat, Nevada Test Site, Nye County, Nevada
}

Scientific Investigations Report 2005-5211

Prepared in cooperation with the U. S. Department of Energy,

National Nuclear Security Administration,

Office of Environmental Management, Nevada Site Office

under Interagency Agreement DE-AI52-01NV13944 



\section{Hydraulic Characterization of Overpressured Tuffs in Central Yucca Flat, Nevada Test Site, Nye County, Nevada}

By Keith J. Halford, Randell J. Laczniak, and Devin L. Galloway

Prepared in cooperation with the U. S. Department of Energy,

National Nuclear Security Administration, Office of Environmental Management,

Nevada Site Office under Interagency Agreement DE-Al52-01NV13944

Scientific Investigations Report 2005-5211

U.S. Department of the Interior

U.S. Geological Survey 


\section{U.S. Department of the Interior \\ Gale A. Norton, Secretary}

\section{U.S. Geological Survey \\ P. Patrick Leahy, Acting Director}

Use of trade, product, or firm names in this report is for identification purposes only and does not constitute endorsement by the U.S. Geological Survey.

Carson City, Nevada, 2005

For additional information write to:

U.S. Geological Survey

Director, USGS Nevada Integrated Science Center

333 West Nye Lane, Room 203

Carson City, NV 89706-0866

Email: GS-W-NVpublic-info@usgs.gov

URL: http://nevada.usgs.gov/

For more information about the USGS and its products:

Telephone: 1-888-ASK-USGS

World Wide Web: http://www.usgs.gov/

Although this report is in the public domain, permission must be secured from the individual copyright owners to reproduce any copyrighted materials contained within this report.

Scientific Investigations Report 2005-5211 


\section{Contents}

Abstract
Introduction.
Purpose and Scope
Desnowledgments
Hydraulic Characterization of Bedded Tuffs
Croms
Initial-Head Distribution
Model Calibration
Model Results.

\section{Figures}

Figure 1. General area of study showing physiographic, hydrologic, geologic, and underground test features in the Yucca Flat area of the Nevada Test Site.

Figure 2. Generalized east-west geologic section across the overpressured area of central Yucca Flat. 3

Figure 3. Anomalous ground-water levels measured during and after period of underground nuclear testing in bedded tuffs within the overpressured area of central Yucca Flat................................... 5

Figure 4. InSAR-derived subsidence for three sequential time periods in overpressured area of

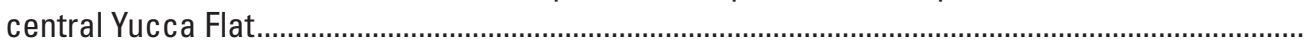

Figure 5. Cumulative regional-range displacement of land surface along three profiles across the overpressured area of central Yucca Flat, April 24, 1992-June 16, 1997 ....................................... 9

Figure 6. Average subsidence rate in central subsidence trough determined from three timesequenced interferograms ........................................................................................................ 10

Figure 7. Location of cross-sectional and three-dimensional models used to estimate hydraulic properties of bedded tuffs in overpressured area of central Yucca Flat....................................... 14

Figure 8. Time line showing water-level and subsidence measurements used as observations to calibrate cross-sectional and three-dimensional models, and detonations used to develop three-dimensional model

Figure 9. Initial-head distribution estimated for model simulation using horizontal and vertical shape functions developed for cross-sectional model. 
Figure 10. Comparison of observed water levels and water levels simulated with cross-sectional and three-dimensional models at: (A) at UE-4t 1 and (B) U-4u PS 2A.

Figure 11. Comparison between observed subsidence and subsidence simulated with crosssectional and three-dimensional models along cross-sectional model trace, April 24, 1992-June 16, 1997.

Figure 12. Finite-difference grid, lateral model boundaries, and grid used for subsidence-rate observations

Figure 13. Normalized linear and cube-root functions used to simulate initial hydraulic head increases at and away from a nuclear detonation.

Figure 14. Comparison of observed subsidence rates and subsidence rates simulated with crosssectional and three-dimensional models for different time periods between April 24, 1992, and June 16, 1997.

Figure 15. Simulated subsidence and general areas of greatest difference between simulated and measured values for period April 24, 1992-June 16, 1997

Figure 16. Simulated water-level change for period April 24, 1992-June 16, 1997. (A) model layer 5, (B) across model row 48, and (C) across model column 41

Figure 17. Simulated water-level changes in model layer 5 through (A) March 5, 1967; (B) July 10, 1977; (C) June 28, 1987; and (D) October 23, 1997.

Figure 18. Simulated $(A)$ cumulative discharge into water table and underlying carbonate rock, and water-level changes in (B) water table, and in (C) overpressured tuff at selected locations in model layer 8, 1962 through 2003

Figure 19. Simulated and predicted $(A)$ cumulative discharge into water table and underlying carbonate rock, and water-level changes in (B) water table, and in (C) overpressured tuff at selected locations in model layer 8, 1962 through 2500.

\section{Tables}

Table 1. Hydraulic conductivity estimated by slug-test analysis of drilling-recovery data for wells completed in bedded tuffs in or near the overpressured area of central Yucca Flat.......

Table 2. Synthetic aperture radar (SAR) images and interferograms processed by differencing two SAR images of central Yucca Flat area

Table 3. Underground nuclear tests in or near the overpressured area of central Yucca Flat.....

Table 4. Shape functions and hydraulic-property parameters estimated or evaluated by crosssectional model.

Table 5. Initial-rise and hydraulic-property parameters estimated or evaluated by three-dimensional model

\section{Appendix}

Appendix. Single-well slug test analyses of postdrilling water-level recovery to estimate hydraulic conductivity of bedded tuffs in overpressured area of central Yucca Flat. 


\section{Conversion Factors and Datums}

\begin{tabular}{lcl}
\hline \multicolumn{1}{c}{ Multiply } & By & \multicolumn{1}{c}{ To obtain } \\
\hline centimeter $(\mathrm{cm})$ & 0.39370 & inch \\
cubic meter $(\mathrm{m} 3)$ & .0008107 & acre-feet \\
cubic meter per second (m3/s) & 35.3147 & cubic feet per second \\
cubic meter per year (m3/yr) & 35.3147 & cubic feet per year \\
kilometer $(\mathrm{km})$ & .62137 & mile \\
kiloton $(\mathrm{kt})$ & 4.1840 & terajoule \\
liter $(\mathrm{L})$ & 3.7854 & gallon \\
meter $(\mathrm{m})$ & 3.2808 & foot \\
meter per day $(\mathrm{m} / \mathrm{d})$ & 3.2808 & feet per day \\
meter per year $(\mathrm{m} / \mathrm{yr})$ & 3.2808 & feet per year \\
millimeter $(\mathrm{mm})$ & 0.03937 & inch \\
millimeter per year $(\mathrm{mm} / \mathrm{yr})$ & .03937 & inch per year \\
millions of square meters $(\mathrm{Mm} 2)$ & .38610 & square mile \\
square kilometer $(\mathrm{km} 2)$ & .38610 & square mile \\
square meter per day $(\mathrm{m} 2 / \mathrm{d})$ & 3.2808 & square feet per day \\
\hline
\end{tabular}

Temperature in degrees Celsius $\left({ }^{\circ} \mathrm{C}\right)$ may be converted to degrees Fahrenheit $\left({ }^{\circ} \mathrm{F}\right)$ as:

$$
{ }^{\circ} \mathrm{F}=\left({ }^{\circ} \mathrm{C} * 1.8\right)+32 .
$$

Vertical coordinate information is referenced to "North American Vertical Datum of 1929 (NAVD 29)."

Horizontal coordinate information is referenced to "North American Datum of 1927 (NAD 27)." Altitude refers to a distance above vertical datum. 


\title{
Hydraulic Characterization of Overpressured Tuffs in Central Yucca Flat, Nevada Test Site, Nye County, Nevada
}

\author{
By Keith J. Halford, Randell J. Laczniak, and Devin L. Galloway
}

\section{ABSTRACT}

A sequence of buried, bedded, air-fall tuffs has been used extensively as a host medium for underground nuclear tests detonated in the central part of Yucca Flat at the Nevada Test Site. Water levels within these bedded tuffs have been elevated hundreds of meters in areas where underground nuclear tests were detonated below the water table. Changes in the ground-water levels within these tuffs and changes in the rate and distribution of land-surface subsidence above these tuffs indicate that pore-fluid pressures have been slowly depressurizing since the cessation of nuclear testing in 1992. Declines in ground-water levels concurrent with regional land subsidence are explained by poroelastic deformation accompanying ground-water flow as fluids pressurized by underground nuclear detonations drain from the host tuffs into the overlying water table and underlying regional carbonate aquifer. A hydraulic conductivity of about $3 \times 10^{-6} \mathrm{~m} / \mathrm{d}$ and a specific storage of $9 \times 10^{-6} \mathrm{~m}^{-1}$ are estimated using ground-water flow models. Cross-sectional and three-dimensional ground-water flow models were calibrated to measured water levels and to land-subsidence rates measured using Interferometric Synthetic Aperture Radar. Model results are consistent and indicate that only about 2 million $\mathrm{m}^{3}$ of ground water flowed from the tuffs to the carbonate rock as a result of pressurization caused by underground nuclear testing. The simulated annual rate of inflow into the carbonate rock averaged about 0.008 $\mathrm{m} / \mathrm{yr}$ between 1962 and 2005, and declined from $0.005 \mathrm{~m} / \mathrm{yr}$ in 2005 to $0.0005 \mathrm{~m} / \mathrm{yr}$ by 2300 .

\section{INTRODUCTION}

Tests of nuclear devices detonated underground at the Nevada Test Site (NTS) between 1951 and 1992 in Yucca Flat deformed the land surface (fig. 1). Craters typically appear days after a detonation and result from the structural failure of a subsurface cavity created by an underground nuclear test. Less obvious is persistent, smaller-magnitude, regionalscale land subsidence in areas where underground nuclear devices were detonated at depths near or below the water table (Laczniak and others, 2003; Vincent and others, 2003). This land subsidence has been measured and mapped using Interferometric Synthetic Aperture Radar (InSAR). As mapped in
Yucca Flat, this smaller-magnitude subsidence generally coincides with areas of unusually high ground-water levels and has been occurring during periods in which water levels have been declining toward pretest levels (Hawkins and others, 1988, 1990; Laczniak and others, 2003; Fenelon, 2005).

Persistent, anomalously high water levels have been observed in wells open to the bedded tuffs in the area between the Yucca and Topgallant faults in central Yucca Flat (Hawkins and others, 1988, fig. 1). These elevated water levels have been attributed to pore-fluid pressurization resulting from the compaction of water-saturated rock by the outward propagation of the high-energy, compressional, seismic waves emanating from underground detonations (Knox and others, 1965; Burkhard and Rambo, 1991). One plausible explanation for this gradual subsidence noted in central Yucca Flat is elastic deformation of the saturated, bedded tuffs in response to the dissipation of fluid pressure that accompanies the delayed drainage of fluid.

The effect of increased hydraulic gradients caused by elevated water levels in the bedded tuffs of central Yucca Flat on the potential transport of radionuclides is critical in assessing risks associated with past underground testing of nuclear devices. Of particular concern is the potential for increased flow into more permeable underlying and overlying rocks or into bounding faults that may provide pathways by which radionuclides could be transported long distances. The hydraulic properties and mechanisms that control ground-water flow and transport in these bedded tuffs are not well understood. An analysis of the relation between ongoing ground-water level declines and regional-scale subsidence measured throughout central Yucca Flat can provide insight to the hydraulic properties controlling ground-water flow and aquifer-system deformation.

\section{Purpose and Scope}

The purpose of this report is to investigate the mechanisms causing and the consequences of elevated water levels in the overpressured area of central Yucca Flat (fig. 1). The report characterizes hydraulic properties of the tuffs and evaluates the potential for increased ground-water flow into underlying, permeable carbonate rock caused by the pressurization of fluids resulting from underground nuclear testing. Hydraulic conductivity is characterized on the basis of slug-test analyses of drilling-recovery data and by parameter estimation 

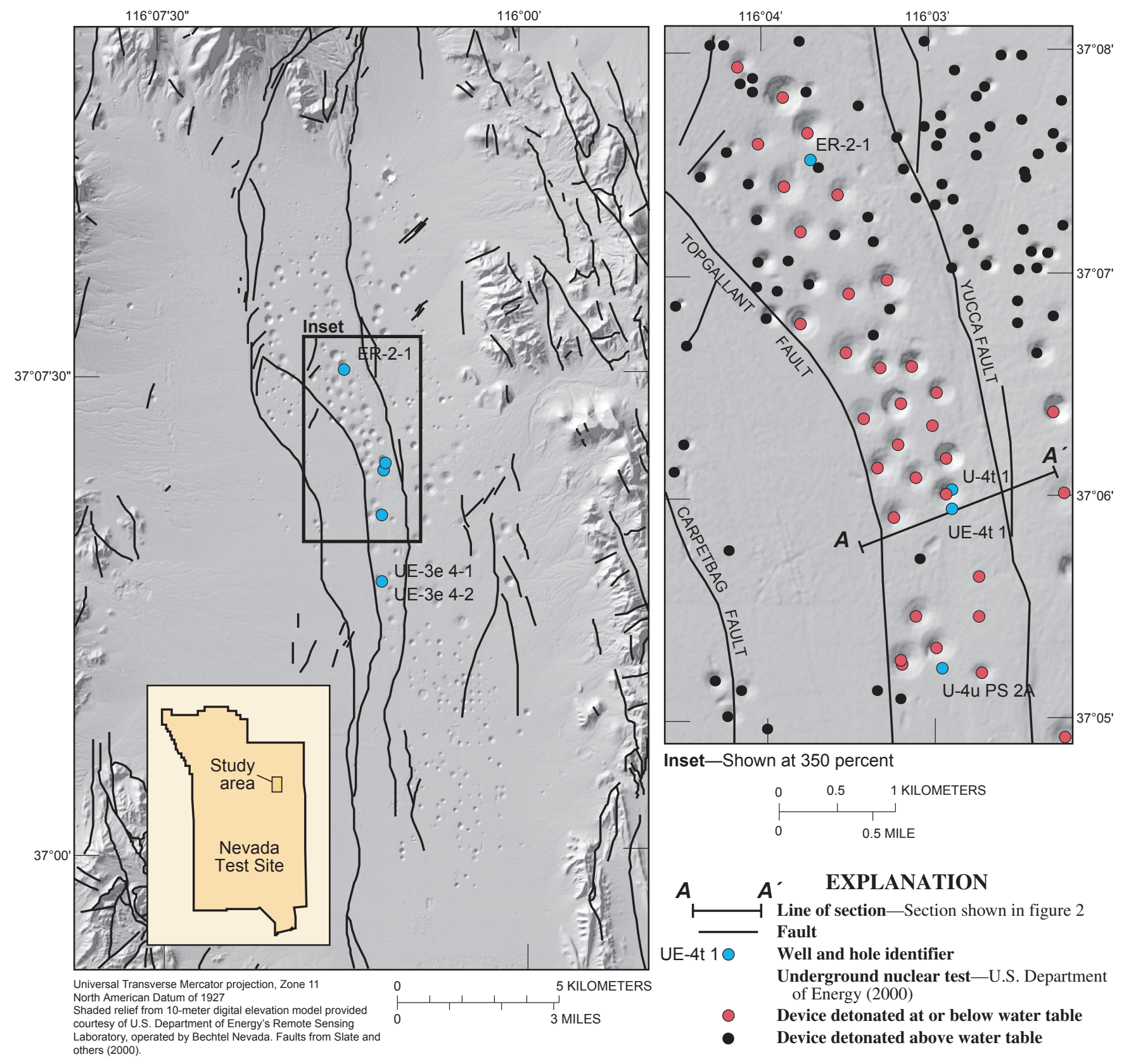

Figure 1. General area of study showing physiographic, hydrologic, geologic, and underground test features in the Yucca Flat area of the Nevada Test Site. 
using two- and three-dimensional ground-water flow models calibrated to measured water levels and InSAR-derived subsidence rates. Storage properties are estimated by the calibration of a three-dimensional ground-water flow model. Estimates of flow into adjacent more permeable rock are based solely on model simulations.

\section{Acknowledgments}

The U.S. Department of Energy, National Nuclear Security Administration, Nevada Site Office, Office of Environmental Management supported this work under Interagency Agreement DE-AI52-01NV13944. Los Alamos National Laboratory (LANL) provided various data, well logs, and historic documents related to the study area. Andrew Wolfsberg and Ward Hawkins of LANL provided valuable early direction, open discussion, and constructive comments during the course of this study. Synthetic aperture-radar data used in this study were acquired from the European Space Agency and provided through Eurimage Corporation for purposes of research and development.

\section{Description of Study Area}

The study area centers on a region in the central part of Yucca Flat between the eastward-dipping Yucca and Topgallant fault systems (figs. 1 and 2). A dominant rock within this fault block is a thick sequence of primarily Tertiary-age, airfall, bedded tuffs that is overlain by Quaternary-age alluvium and underlain by Paleozoic-age carbonate rock at depth (fig. 2 ). Bedded tuffs of this rock sequence have been well characterized through extensive investigations associated with underground testing of nuclear devices (App and Marusak, 1997). Below the water table, these rocks are highly zeolitized and are described as being of low permeability and high porosity (Winograd and Thordarson, 1975, p. 44; Flint, 1998); characteristics which have made them a preferred media for underground nuclear testing (App and Marusak, 1997). Between 1960 and 1990, nearly 115 underground nuclear devices were tested in this general area of central Yucca Flat (fig. 1; U.S. Department of Energy, 1997, 2000). About 35 of these tests detonated nuclear devices between the Yucca and Topgallant faults in bedded, air-fall tuffs below the water table (fig. 1). The area inclusive of these test locations defines the approximate boundary of the study area.

\section{EXPLANATION}

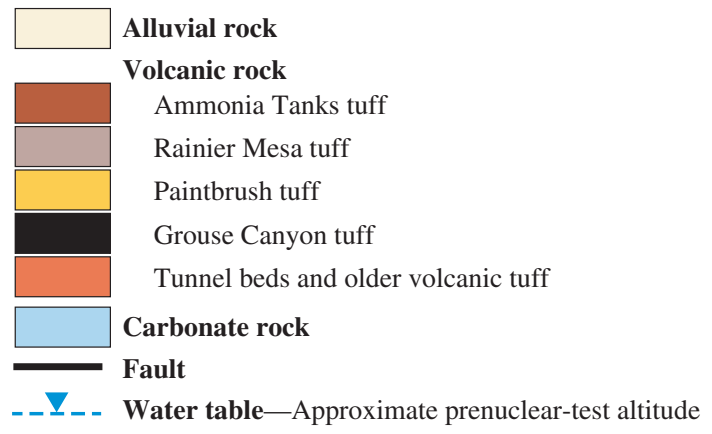

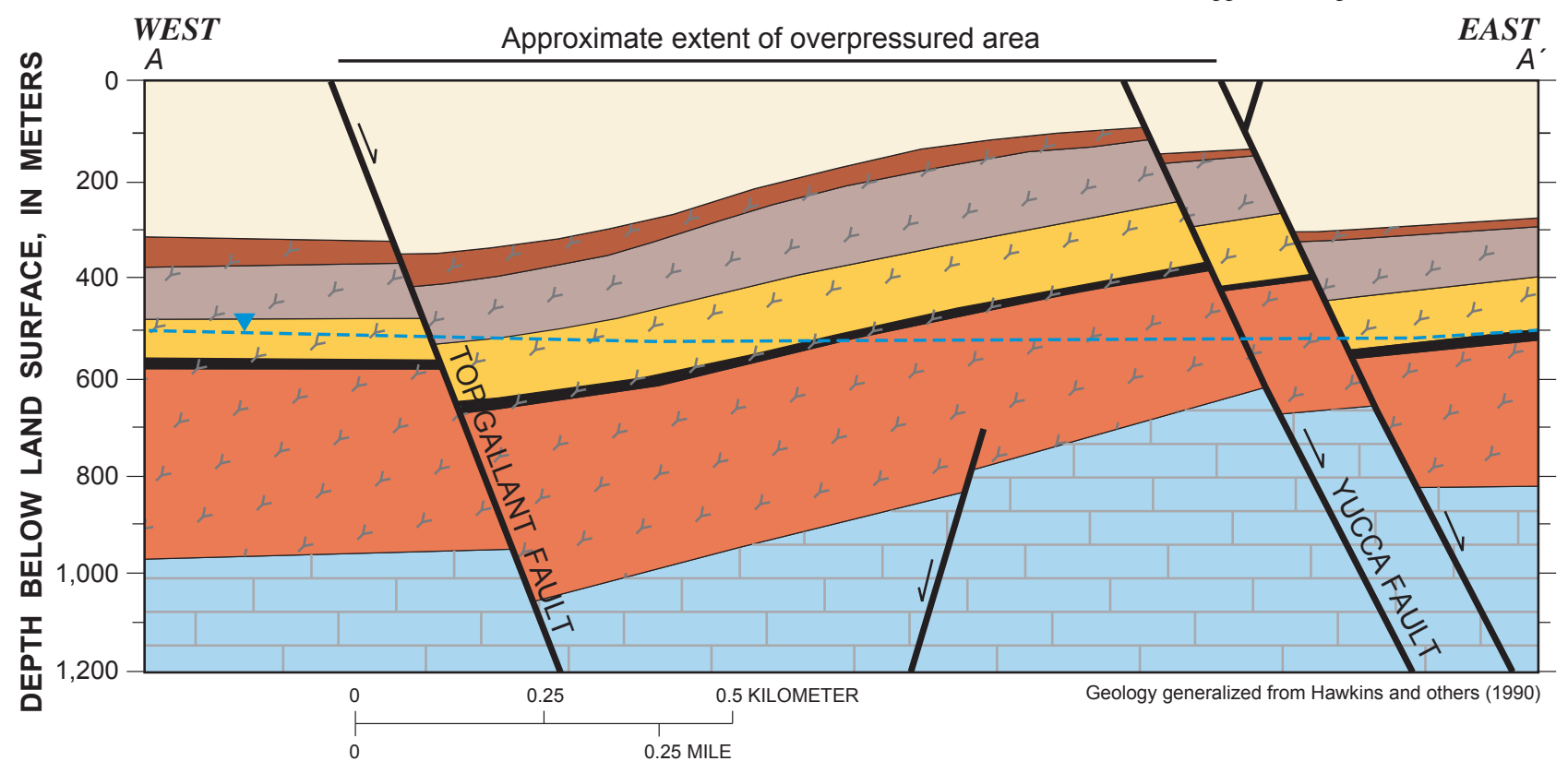

Figure 2. Generalized east-west geologic section across the overpressured area of central Yucca Flat.

Section line shown in figure 1. 
Hydraulic Characterization of Overpressured Tuffs in Central Yucca Flat, Nevada Test Site, Nye County, Nevada

\section{HYDRAULIC CHARACTERIZATION OF BEDDED TUFFS}

The hydraulic and mechanical responses of bedded tuffs to deformation induced by testing nuclear devices below the water table can be used to estimate the hydraulic properties of the bedded tuff units in central Yucca Flat. Ground-water levels measured in wells penetrating the bedded tuffs and land subsidence measured in and around the Yucca Flat testing area can be described by a transient poroelastic response to deformation and fluid pressurization. These measurements along with models of poroelastic response are used to constrain estimates of hydraulic conductivity, storage, and ground-water flux.

\section{Ground-Water Levels}

Ground-water levels have been measured throughout the study area at various frequencies since the mid-1950s (U.S. Geological Survey, 2005). Prior to nuclear testing, water levels in wells open to volcanic units in the study area ranged from about 750 to $785 \mathrm{~m}$ above sea level (Doty and Thordarson, 1983; Hale and others, 1995; D’Agnese and others, 1998). Hydraulic gradients estimated from pretest measurements made in wells throughout the study area indicate that flow, prior to underground nuclear testing, was downward from the Quaternary-age alluvial rock, through the Tertiary-age volcanic rock, and into the underlying Paleozoic-age carbonate rock (fig. 2; Winograd and Thordarson, 1975; Doty and Thordarson, 1983; Hale and others, 1995; Fenelon, 2005). Downward flow into the carbonate rock, which constitutes the regional carbonate aquifer, likely is impeded by the low interstitial permeability of the intervening, zeolitically altered tuffs (Winograd and Thordarson, 1975).

Water levels in wells open to bedded tuffs in central Yucca Flat measured during and after underground nuclear testing indicate a significant rise (hundreds of meters) from pretest, ground-water levels (wells UE-3e4-1, UE-3e4-2, ER-2-1, UE-4t 1, and U-4t 1; figs. 1 and 3). Water levels in these wells initially rose for a period of a few months to a few years after drilling. This initial rise is followed by a long, sustained period of decline toward pretest levels (fig. 3). The highest ground-water level measured within the study area was nearly 1,200 $\mathrm{m}$ above mean sea level in well UE-4t 1 -a rise of nearly $450 \mathrm{~m}$ from the pretest level (fig. 3). Since the peak water level in late 1992, water levels in well UE-4t 1 have declined nearly 80 m over a 12-year period (1992-2004). Water-level measurements made in other wells within the study area open to similar bedded tuffs show a qualitatively similar response (wells UE-3e4-1, UE-3e4-2, and ER-2-1; figs. 1 and 3).

Water levels in wells open to cavities respond opposite to the declining trend observed in wells open to tuffs (fig. 3). For example, well U-4u PS $2 \mathrm{~A}$ is a postshot hole, a reentry shaft drilled into the cavity created by an underground nuclear test, that shows a rising trend. Early water levels measured in this well were nearly $50 \mathrm{~m}$ below the pretest water level. This period of depressed water levels has been followed by a long period of water-level rise (fig. 3). The hydrograph in this well resembles that of a well recovering from pumping and the response is assumed to represent infilling of the test cavity (Laczniak and other 2003; Fenelon, 2005). A similar waterlevel response noted in a postshot hole at the Faultless nuclear test in central Nevada also has been attributed to cavity infilling (Thordarson, 1987).

Posttest water-level measurements made in wells open to more permeable, volcanic- or alluvial-rocks overlying the bedded tuffs or to underlying carbonate rocks show no equivalent large-magnitude response in water levels (Fenelon, 2005). Hydraulic gradients across the bedded tuffs computed from posttest measurements indicate upward flow into the overlying water table and downward flow into underlying carbonate rock. This bidirectional flow is in contrast to downward flow inferred from pretest measurements. Likewise, flow rates were increased from pretest conditions owing to larger hydraulic gradients.

The low permeability of the bedded tuffs is evidenced by the slow rise of water levels in response to drilling and nuclear testing. Water levels measured in wells open to bedded-tuff units typically take months to years to reach equilibrium after drilling. Postdrilling, water-level recoveries from wells open to bedded tuffs were analyzed as single-well slug tests (Bouwer and Rice, 1976) to estimate hydraulic conductivity. The application of the slug-test method assumes that the hydraulic stress of drilling and completion activities on these wells is instantaneous relative to the long recovery periods. Hydraulic conductivities estimated in nine wells completed in bedded-tuff units using this method are consistently low and range between $3 \mathrm{x}$ $10^{-7}$ and $9 \times 10^{-4} \mathrm{~m} / \mathrm{d}$ (table 1 , app. 1). This range falls within the range of values for zeolitized and clayey tuff determined by analyzing 72 cores (Winograd and Thordarson, 1975). The geometric mean of the nine estimates, $3 \times 10^{-5} \mathrm{~m} / \mathrm{d}$, is similar in magnitude to hydraulic conductivities measured in unweathered, marine clays (Wolff, 1982).

\section{Land-Surface Displacement}

Land-surface displacements in Yucca Flat associated with the testing of nuclear devices emplaced deep (greater than hundreds of meters) below the land surface generally are expressed as local- and regional-scale features. Localscale features include surface craters a few meters to tens of meters deep that form above an underground nuclear test when overlying material collapses into a cavity formed during and after the device is detonated. Surface craters measure tens to hundreds of square meters in area and are prominent features on the Yucca Flat landscape (fig. 1). Regional-scale features cover broad areas where subsidence is measured in millimeters and centimeters. Relative subsidence between the Yucca and 


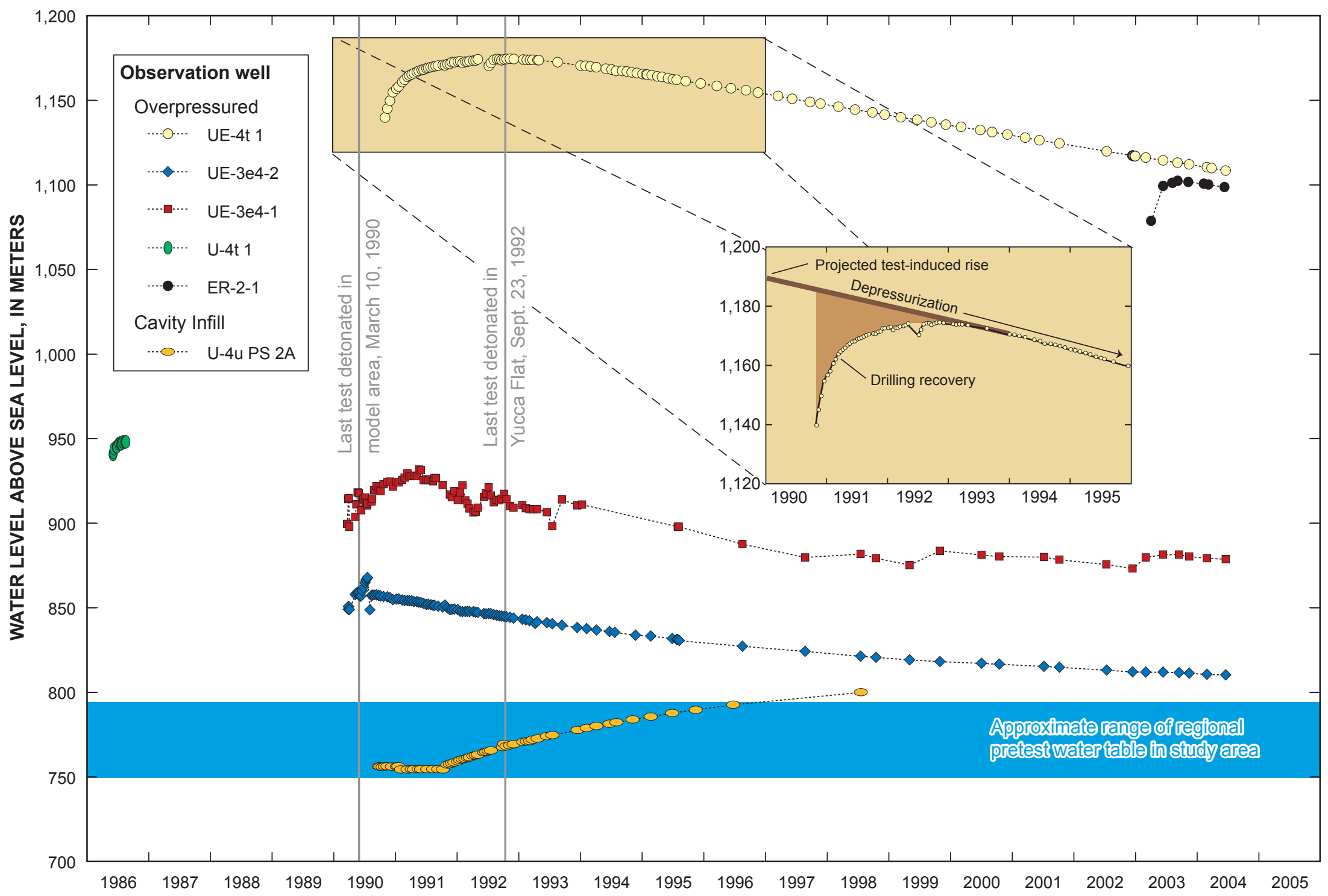

Figure 3. Anomalous ground-water levels measured during and after period of underground nuclear testing in bedded tuffs within the overpressured area of central Yucca Flat.

Well U-4t 1 and UE-4t 1 are only wells in model area (fig. 7). 
Table 1. Hydraulic conductivity estimated by slug-test analysis of drilling-recovery data for wells completed in bedded tuffs in or near the overpressured area of central Yucca Flat

[Hole identifier is assigned by U.S. Department of Energy to identify drill holes on Nevada Test Site. Site number is assigned by U.S. Geological Survey to identify drill holes throughout United States]

\begin{tabular}{|c|c|c|c|c|c|c|c|c|c|}
\hline $\begin{array}{c}\text { Hole } \\
\text { identifier }\end{array}$ & Site number & Latitude & Longitude & $\begin{array}{l}\text { Depth to top } \\
\text { of screen } \\
\text { opening } \\
\text { (meters) }\end{array}$ & $\begin{array}{l}\text { Depth to bot- } \\
\text { tom of screen } \\
\text { opening } \\
\text { (meters) }\end{array}$ & $\begin{array}{l}\text { Depth to } \\
\text { water } \\
\text { (meters) }\end{array}$ & Date drilled & $\begin{array}{c}\text { Casing diam- } \\
\text { eter } \\
\text { (meters) }\end{array}$ & $\begin{array}{c}\text { Hydraulic } \\
\text { conductivity } \\
\text { (meters per day) }\end{array}$ \\
\hline $\mathrm{U}-2 \mathrm{bs}$ & 370723116033101 & $37^{\circ} 07^{\prime} 22.97^{\prime \prime}$ & $116^{\circ} 03^{\prime} 30.65^{\prime \prime}$ & 24 & 585 & 562 & 01/28/1971 & 2.54 & $9 \times 10^{-4}$ \\
\hline $\mathrm{U}-2 \mathrm{bt}$ & 370641116030501 & $37^{\circ} 06^{\prime} 41.39^{\prime \prime}$ & $116^{\circ} 03^{\prime} 05.07^{\prime \prime}$ & 23 & 549 & 543 & 04/07/1971 & 0.95 & $9 \times 10^{-4}$ \\
\hline $\mathrm{U}-2 \mathrm{gh}$ & 370645116031901 & $37^{\circ} 06^{\prime} 45.01^{\prime \prime}$ & $116^{\circ} 03^{\prime} 18.64^{\prime \prime}$ & 36 & 549 & 481 & 08/01/1988 & 2.5 & $2 \times 10^{-4}$ \\
\hline $\mathrm{U}-2 \mathrm{gk}$ & 370720116041601 & $37^{\circ} 07^{\prime} 20.47^{\prime \prime}$ & $116^{\circ} 04^{\prime} 16.36^{\prime \prime}$ & 35 & 551 & 550 & 10/27/1992 & 2.5 & $1 \times 10^{-5}$ \\
\hline U-4t 1 & 370601116025301 & $37^{\circ} 06^{\prime} 01.54^{\prime \prime}$ & $116^{\circ} 02^{\prime} 53.54^{\prime \prime}$ & 36 & 640 & 322 & 06/04/1986 & 0.34 & $6 \times 10^{-6}$ \\
\hline U-7cd 1 & 370451116024102 & 370'ㄷ․14" & $116^{\circ} 02^{\prime} 40.9^{\prime \prime}$ & 35 & 518 & 511 & 09/16/1992 & 0.48 & $2 \times 10^{-4}$ \\
\hline UE-4ab & 370608116043102 & $37^{\circ} 06^{\prime} 08.32^{\prime \prime}$ & $116^{\circ} 04^{\prime} 31.13^{\prime \prime}$ & 22 & 730 & 551 & 08/03/1973 & 0.41 & $6 \times 10^{-7}$ \\
\hline UE-4t 1 & 370556116025405 & $37^{\circ} 05^{\prime} 56.13^{\prime \prime}$ & $116^{\circ} 02^{\prime} 53.73^{\prime \prime}$ & 581 & 613 & 122 & 11/02/1990 & 0.06 & $3 \times 10^{-7}$ \\
\hline UE-8e & 371014116051601 & $37^{\circ} 10^{\prime} 14.26^{\prime \prime}$ & $116^{\circ} 05^{\prime} 15.55^{\prime \prime}$ & 22 & 646 & 611 & $12 / 14 / 1970$ & 0.34 & $9 \times 10^{-6}$ \\
\hline
\end{tabular}


Topgallant faults measured using InSAR was $10 \mathrm{~mm}$ to greater than $100 \mathrm{~mm}$ for the period April 24, 1992-June 16, 1997 (fig. 4). These regional-scale features result from smaller-magnitude displacements, encompass square kilometers, and coincide with nuclear tests detonated below the water table (fig. 4). Regional-scale subsidence in central Yucca Flat has been attributed to poroelastic deformation of saturated rock since the cessation of underground nuclear testing in 1992 (Laczniak and others, 2003; Vincent and others, 2003).

InSAR is a remote sensing technique that has been used to map and measure land-surface displacements caused by earthquakes, volcanoes, landslides, and other man-induced processes including subsurface fluid pumping of geothermal and petroleum reservoirs and aquifer systems (Rosen and others, 2000). The InSAR technique uses phase measurements to resolve millimeter-level variations in range between the radar transimitter/receiver and ground reflectors. For this study, satellite-borne radar instruments were used. Systematic errors introduced by uncertainties in satellite orbits and changes in signal propagation through the troposphere can bias InSARderived land-surface displacements. Small inaccuracies in satellite orbits introduce relatively linear phase trends across the interferogram (Zebker and others, 1994). Typically, these trends can be corrected by removing a best-fit plane to minimize the effect of these artifacts within the image. A comprehensive review of InSAR applications to measure changes of Earth's surface is given in Massonnet and Feigl (1998), and a review of applications in geomorphology and hydrology is in Smith (2002).

Three time-sequential interferograms representing relative range displacement maps (fig. 4) of land surface from April 24, 1992, to June 16, 1997, were developed using differential interferometry processing software (Centre National d'Etudes Spatiales,1997). Three pairs of raw synthetic aperture radar (SAR) images were combined from four repeat-pass SAR images of Yucca Flat acquired from the European Space Agency's ERS-1 and ERS-2 satellites (table 2). To minimize the topographic influence, the repeat-pass SAR image pairs used to develop the interferograms were selected to minimize the perpendicular baseline between their orbits, and a 30-mresolution digital elevation model (DEM) of the Yucca Flat area was used in the interferometric processing to subtract topographic components. Tropospheric errors in the images were evaluated on the basis of the presence or absence of atmospheric artifacts in the interferograms. The interferograms were processed at $40-\mathrm{m}$ resolution in the geometry of the radar, and subsequently georeferenced and resampled at the 30-m resolution of the DEM. Finally, the interferograms were smoothed and scaled to represent range (line-of-sight of the radar sensor) displacements. In Yucca Flat, true vertical displacement is about 1.09 times the range displacement assuming all range displacement results from vertical movement of land surface. The absence of atmospheric artifacts, correction for orbital errors, and selection of image pairs with favorable orbital geometries to minimize topographic effects leads us to estimate accuracies of the measured range displacements in central Yucca Flat at $\pm 5 \mathrm{~mm}$. A more complete description of the technique used to reduce measurement errors and to enhance the accuracy of measured displacements is explained in Hoffmann and others (2001).

Table 2. Synthetic aperture radar (SAR) images and interferograms processed by differencing two SAR images of central Yucca Flat area

[Radar images acquired by European Remote Sensing (ERS) satellites: track 399, frame 2871 (shifted -9)]

\begin{tabular}{lcccc}
\hline Satellite & $\begin{array}{c}\text { Orbit } \\
\text { number }\end{array}$ & $\begin{array}{c}\text { Acquisition } \\
\text { date }\end{array}$ & $\begin{array}{c}\text { Interfer- } \\
\text { ogram }\end{array}$ & $\begin{array}{c}\text { Baseline } \\
\text { (meters) }\end{array}$ \\
\hline ERS-1 & 4051 & $04 / 24 / 92$ & & +42 \\
ERS-1 & 10063 & $06 / 18 / 93$ & & \\
ERS-1 & 20427 & $06 / 11 / 95$ & $93-95$ & +59 \\
& & & & \\
& & & $95-97$ & +11 \\
\hline
\end{tabular}

Interferograms for three sequential time periods (April 24, 1992-June 18, 1993; June 18, 1993-June 11, 1995; and June 11, 1995-June 16, 1997) are shown in figure 4. Range displacements are shown using a repeating color spectrum scaled $28 \mathrm{~mm}$ per color cycle for ease of viewing small changes in the displacement map. Figure 5 shows cumulative regional-range displacement measured along three profiles through the overpressured area of central Yucca Flat. Cumulative displacement was derived by summing displacement values interpolated from the three time-sequential interferograms. Portions of these interferograms were published previously in Bawden and others (2003), Laczniak and others (2003), and Vincent and others (2003).

Displacement maps reveal relative subsidence of as much as $150 \mathrm{~mm}$ during a 5-year period at the center of oval troughs (fig. 4). These features generally surround multiple underground nuclear test locations, many of which cratered the land surface (fig. 1). Most subsidence is concentrated in the region between the Yucca and Topgallant faults where numerous nuclear devices were detonated below the water table (fig. 1). The general absence of subsidence beyond the fault block suggest that these bounding faults control the areal extent of test-generated land-surface displacements in the overpressured area of Yucca Flat (Laczniak and others, 2003).

The testing of nuclear devices at the NTS was suspended in September 1992. One likely explanation for the postseismic deformation observed through 1997 is a poroelastic response, defined as the elastic compression of low-permeability tuff units. Elastic compression results from delayed drainage and depressurization of the tuff units following co-seismic pore-fluid pressurization. 


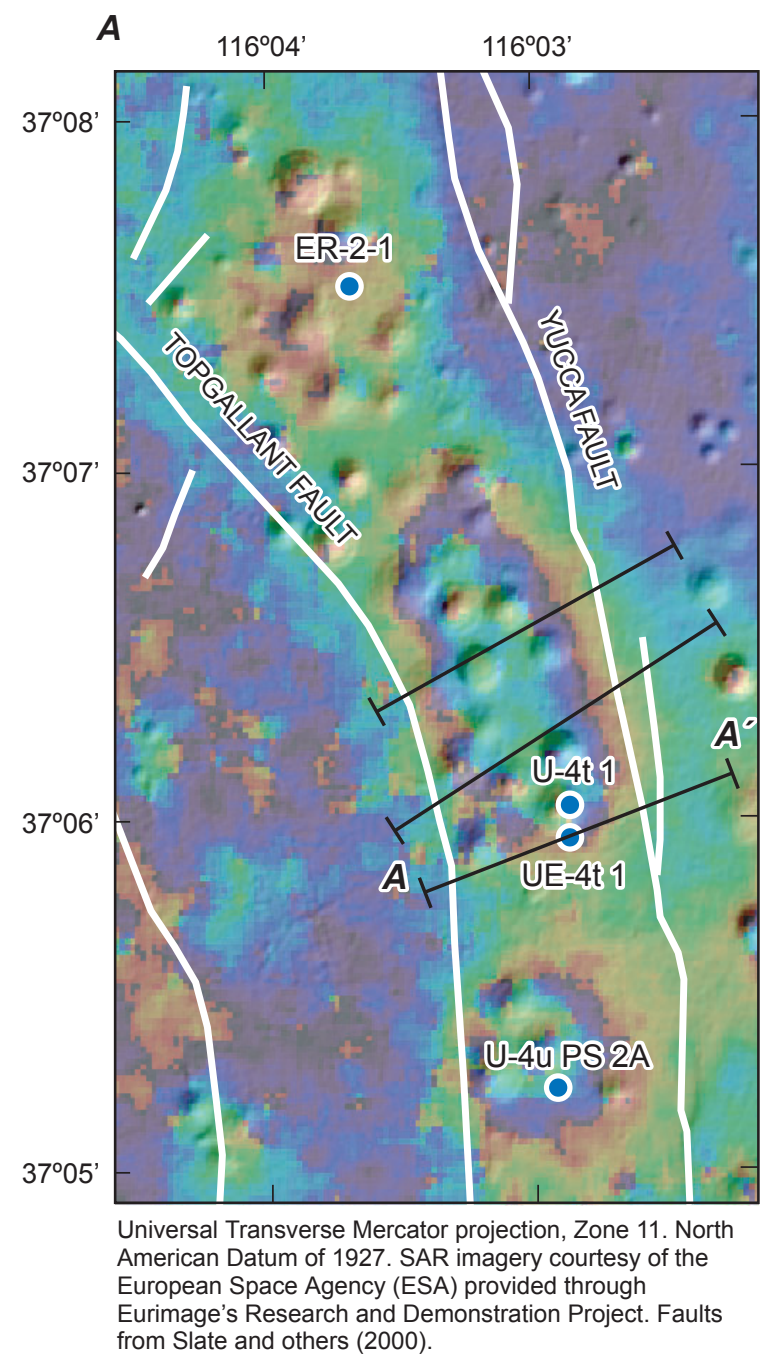

\begin{tabular}{lll}
$B$ & $116^{\circ} 04^{\prime}$ & $116^{\circ} 03^{\prime}$ \\
\hline
\end{tabular}

c

$116^{\circ} 04^{\prime}$

$116^{\circ} 03^{\prime}$
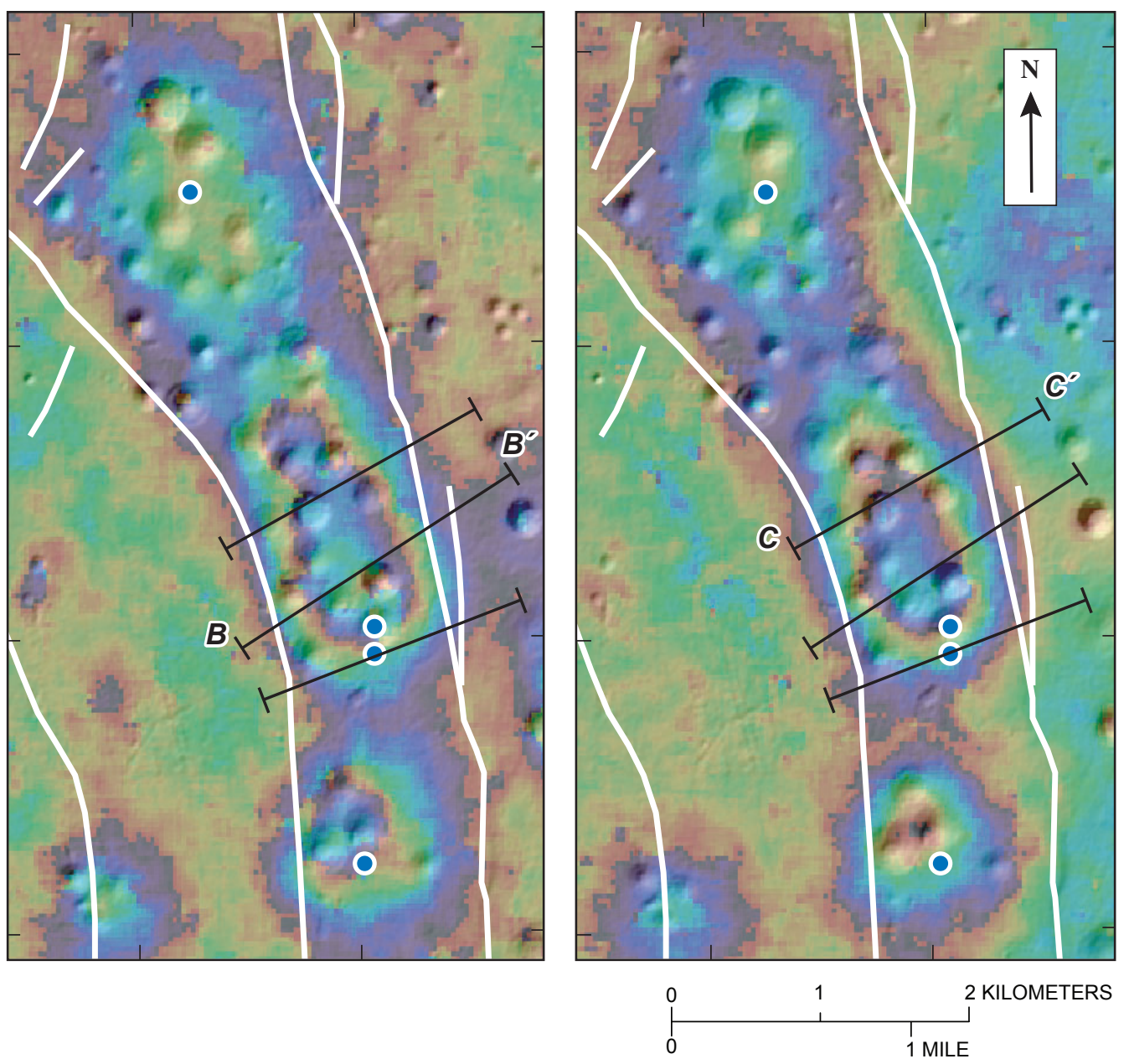

EXPLANATION

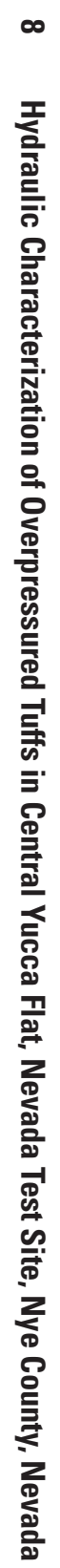

Relative range displacement
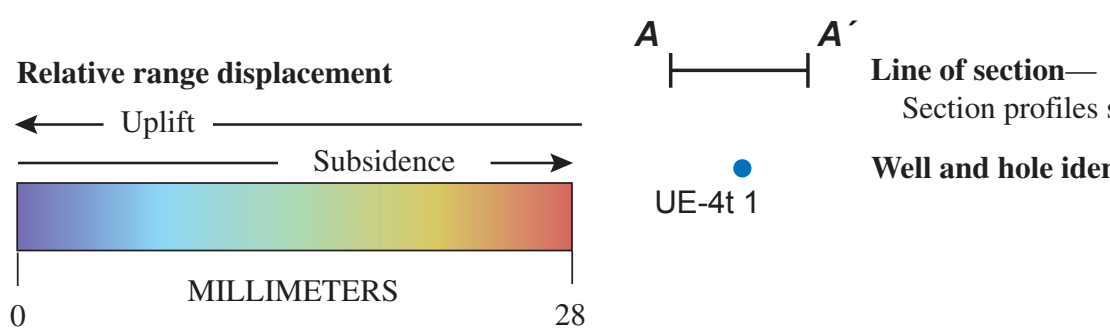

Section profiles shown in figure 5

UE-4t 1

Well and hole identifier

28

Figure 4. InSAR-derived subsidence for three sequential time periods in overpressured area of central Yucca Flat.

(A) April 24, 1992-June 18, 1993; (B) June 18, 1993-June 11,1995; and (C) June 11, 1995-June 16, 1997. 


\section{WEST}

EAST
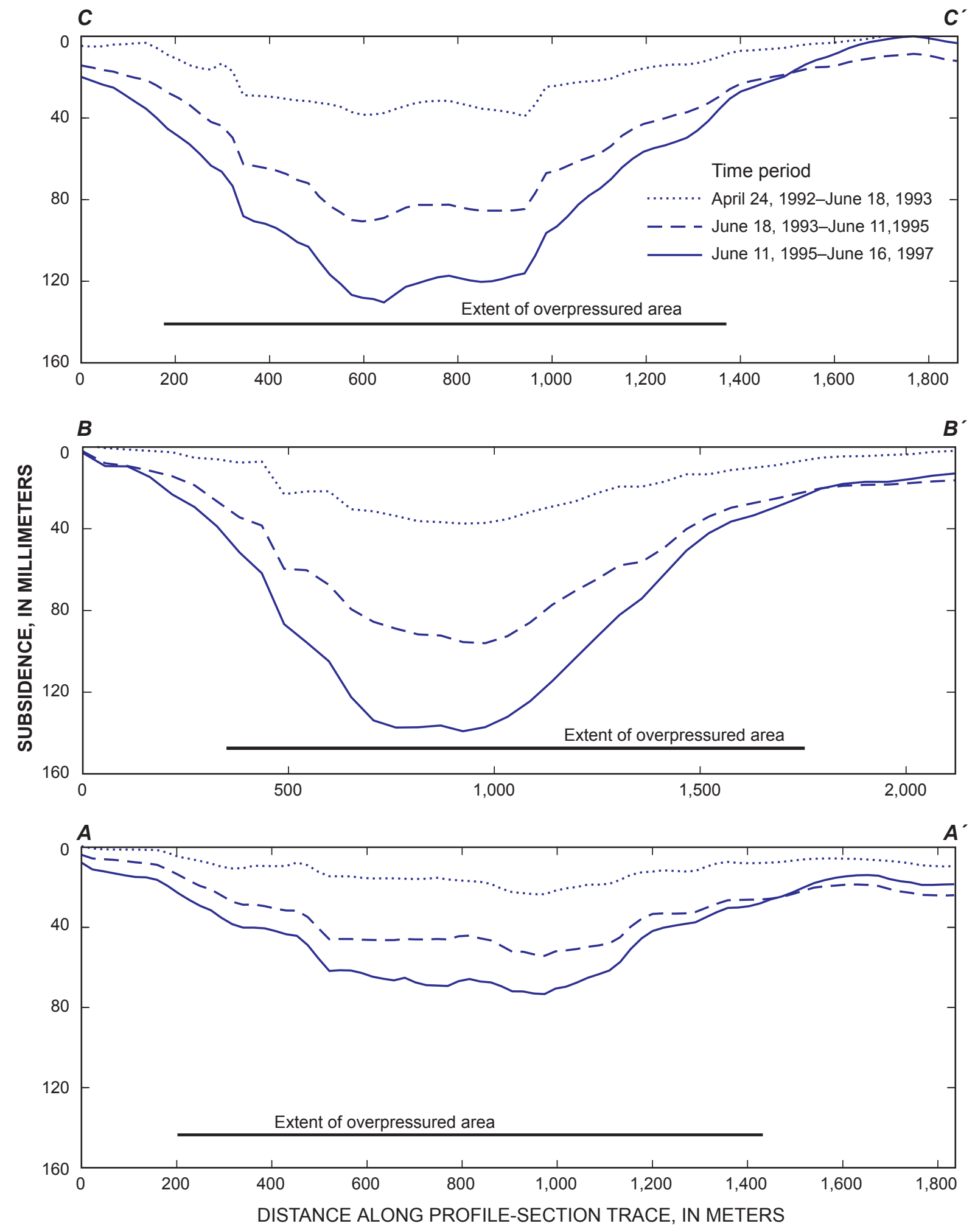

Figure 5. Cumulative regional-range displacement of land surface along three profiles across the overpressured area of central Yucca Flat, April 24, 1992-June 16, 1997. 
Land-surface displacement in the central subsidence trough generally decreased over time (fig. 4). Subsidence rates were computed by averaging pixel range-displacement values in the interferogram within the central subsidence trough, dividing by the time interval of the interferogram, and assigning the rate to the midpoint of the period covered by the inteferogram. Average subsidence rates declined from $16 \mathrm{~mm} / \mathrm{yr}$ in 1992 to $9 \mathrm{~mm} / \mathrm{yr}$ in 1996 (fig. 6).

\section{Conceptual Model}

The conceptual model presented in this report is based on poroelasticity theory (Biot, 1941; Wang, 2000) and simplistically describes the interaction of ground-water flow and skeletal-matrix deformation in a saturated porous, bedded tuff in response to underground nuclear detonations. Laczniak and others (1996) summarize the effect of underground nuclear detonations on ground-water flow in saturated host rocks at the NTS. The plasma and thermal pulse that originates from the point of detonation expands rapidly outward as rock is vaporized, melted, and mechanically disaggregated. A compressional shock wave propagates beyond the cavity creating fractures and slip on preexisting fractures. In the near field, test-induced changes in permeability and storativity result from pervasive fracturing and the formation of a cavity and rubble chimney. Cavity collapse may extend upward to land surface creating a crater at land surface. Within the cavity and rubble chimney, posttest ground-water levels have been measured tens of meters lower than pretest levels (Thordarson, 1987). Beyond the chimney area, radial compressive stresses deform the rock matrix reducing porosity and thereby increasing pore-fluid pressures and ground-water levels in wells open to the affected units (Knox and others, 1965; Burkhard and Rambo, 1991). Ground-water levels measured beyond the chimney area during and following tests indicate that a mound of higher water levels forms immediately following detona- tion and then dissipates by drainage outward and inward to the rubble chimney.

Each nuclear detonation creates a permeable cavity and spherically compacts the low permeability, high porosity tuff beyond the blast cavity-first via a dynamic shock wave and subsequently via a local quasi-static applied stress. A slight reduction in porosity presumably occurs as a result of inelastic compaction. The radial extent of compaction and water-level change has been estimated as 2 cavity radii, which equates to about $600 \mathrm{~m}$ for a test yield of $150 \mathrm{kt}$ (Wohletz and others, 1999). Water-level increases greater than $500 \mathrm{~m}$ in wells open to the overpressured tuff have persisted more than a decade since the cessation of nuclear testing in 1992 (fig. 3). These elevated water levels are attributed to the solid-to-fluid coupling of the deformed host saturated porous rock and the timedependent equilibration of pore-fluid pressure owing in part to the low hydraulic conductivities, $10^{-9}-10^{-3} \mathrm{~m} / \mathrm{d}$ (Wohletz and others, 1999) and overall thickness of the host bedded, air-fall tuffs.

Conceptually, the energy released by the detonation causes a transient increase in total stress within the host rock that propagates spherically and diminishes with distance from the detonation. The coupled hydraulic-mechanical response of the host rock can be described by the effective stress law (Terzaghi, 1925, 1943):

$$
\sigma_{i j}^{\prime}=\sigma_{i j}-\delta_{i j} p
$$

where:

$\sigma_{i j}^{\prime}$ is a component of the effective stress tensor,

$\sigma_{i j}$ is a component of the total stress tensor,

$\delta_{i j}^{i j}$ is Kronecker delta function, and

$p$ is pore-fluid pressure.

Equation 1 shows that changes in total stress are balanced by changes in effective (intergranular) stress and pore-fluid pressure. Within some distance from the detonation, the increased effective stress is greater than the preconsolidation

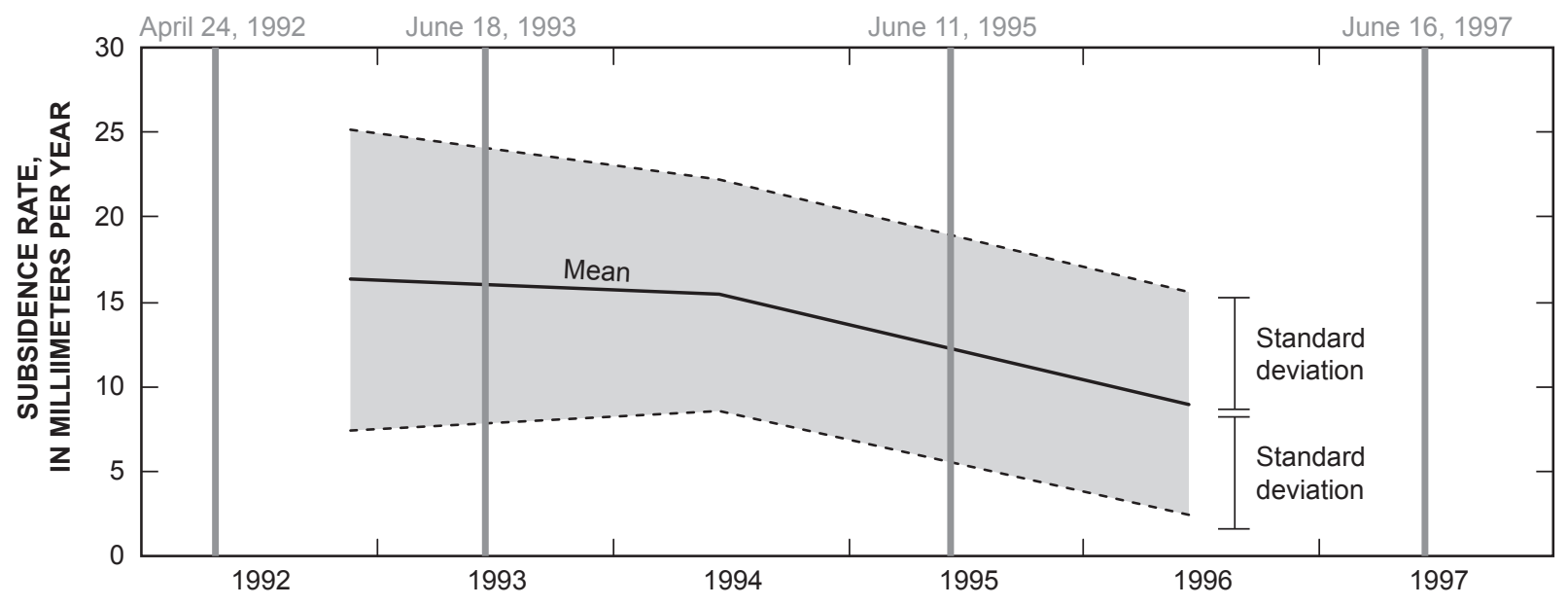

Figure 6. Average subsidence rate in central subsidence trough determined from three time-sequenced interferograms. Central subsidence trough shown on interferograms in figure 4. 
stress of the host rock resulting in inelastic or largely irreversible compression (compaction). Accompanying the compression is an increase in fluid pressure which opposes increases in the effective stress. Because the system undergoing changes in total stress is not a closed system, fluid can migrate through pores and secondary porosity (fractures) to partially reduce the buildup in fluid pressure caused by the increase in effective stress. At some time after the detonation and beyond the local influence of the cavity, the system returns to equilibrium-a state where the total stress is described by the geostatic load and is roughly equivalent to the geostatic load prior to the detonation. The effective stress of the host rock is reduced subject to the elevated confined fluid pressures and the geostatic load.

A slow increase in effective stress in the elastic range accompanies the slow decay or recovery of fluid pressures in the bedded tuff where effective stress is less than the maximum or preconsolidation stress imposed by the detonation. Carbonate rock and welded tuff also are deformed by the detonation but any fluid-pressure change quickly dissipates because of their greater bulk permeability. Similarly, fluid migrating from the host bedded tuff to the overlying water table and underlying carbonate-rock aquifers causes negligible changes in fluid pressures because of their relatively high permeability.

Analyses of ground-water flow systems commonly use hydraulic head rather than pore-fluid pressure,

$$
h=p /\left(\rho_{w} g\right),
$$

where:

$h$ is hydraulic head,

$\rho_{w}$ is density of water, and

$g$ is gravitational acceleration.

In a confined aquifer system, the total stress changes negligibly with changes in head as water is released from or taken into storage as a result of the compression or expansion of the skeletal matrix of the porous medium and (or) the water. Assuming a negligible change in the density of water, the change in effective stress for a given change in head can be expressed as (Poland and Davis, 1969):

$$
\Delta \sigma_{i j}^{\prime}=-\delta_{i j} \rho_{w} g \Delta h \text {. }
$$

For confined ground-water flow, changes in effective stress represented as changes in head are coupled to the flow equations through a storage term. This term accounts for the compressibility of the fluid and skeletal matrix of the saturated system and describes the volume of water released from or taken into storage per unit area of saturated rock per unit change in head:

$S=S_{s} b=\rho g(\alpha+n \beta) b=\left(S_{s k}+S_{s w}\right) b=S_{k}+S_{w}$

where:

$S$ is storage coefficient,

$S$ is specific storage,

$b$ is thickness of saturated-system component, $\alpha$ is matrix compressibility, $n$ is porosity,

$\beta$ is fluid (water) compressibility,

$S^{\text {sk }}$ is skeletal specific storage,

$S_{s w}$ is specific storage of water,

$S_{k}$ is skeletal storage coefficient, and

$S_{w}$ is storage coefficient of water.

The matrix compressibility of a porous medium can be defined as:

$$
\alpha=-\varepsilon_{V} / \Delta \sigma_{i j}^{\prime}=-(\Delta V / V) / \Delta \sigma_{i j}^{\prime}
$$

where:

$\varepsilon_{V}$ is the volume strain, and

$\mathrm{V}$ is the volume of the saturated-system unit.

Matrix compressibility determined using a typical laboratory-loading cell measures the change in thickness of a core sample in response to a load placed on the vertical face of a sample core that is jacketed to constrain any horizontal deformation. Another expression for matrix compressibility can be written as:

$$
\alpha=-(\Delta b / b) / \Delta \sigma_{z z}{ }^{\prime}
$$

where $\sigma_{z z}{ }^{\prime}$ is the vertical component of effective stress.

For a constant total stress, a measure of the change in vertical effective stress is the change in head. Therefore, equation 6 can be written as:

$$
\alpha=-(\Delta b / b) / \Delta h \text {. }
$$

This concept of $\alpha$ is based on one-dimensional vertical deformation, and for most problems of ground-water flow, $\alpha$ is considered an isotropic property within a single saturated-system unit. This simplification results from the relative difficulty in measuring volume displacements versus vertical displacements (for example changes in land-surface altitudes) in aquifer systems. For many cases, changes in the horizontal stress field are small and under ordinary circumstances only significant changes in vertical effective stresses are anticipated (Burbey, 2001a, b).

The analyses and simulations presented in this report address the posttest fluid-to-solid coupling of the aquifer system as it compresses in response to declining pore-fluid pressures measured as changes in ground-water levels in wells open to the overpressured tuffs. The simulations decouple the fluid-flow/mechanical processes. The release of ground water from storage as water levels decline is attributed to the change in storage owing to the skeletal specific storage of the host bedded tuff. The change in storage owing to the compressibility of water generally is about one order of magnitude smaller than the change in storage owing to the skeletal elastic compressibility of unconsolidated aquitards (Riley, 1998). Thus, a proxy expression for storage using equation 4 becomes:

$$
S=\left(S_{s k}\right) b=S_{k} \text {. }
$$


The change in land-surface altitude (subsidence) can be used to estimate the change in storage attributed to compaction of the overpressured-bedded tuffs from the equation:

$$
\Delta S=\left(S_{s k}\right) \Delta b .
$$

Thus, subsidence measurements can directly constrain specific-storage estimates in ground-water flow simulations of the bedded tuffs.

\section{Numerical Models}

Hydraulic conductivity and specific storage of the bedded tuffs in the overpressured area of central Yucca Flat were estimated by calibrating cross-sectional and three-dimensional models to measured water levels and InSAR-derived subsidence rates. Both models were solved with MODFLOW (Harbaugh and McDonald, 1996). A cross-sectional model was developed initially to minimize simulation time and test different model boundary conditions. A three-dimensional model was developed afterward to more accurately depict the interactions of the multiple nuclear tests detonated in the bedded tuffs over a 30 -year period.

The cross-sectional and three-dimensional models are bounded approximately by the Yucca fault on the east and the Topgallant fault on the west and extend beneath land surface to include the entire subsurface distribution of the bedded-tuff sequence (figs. 2 and 7). The cross-sectional model extends across the overpressured area through well UE-4t 1 near the GASCON nuclear test (table 3 and fig. 7). The three-dimensional model extends southward and northward from the crosssectional model to cover an area of about $5 \mathrm{~km}^{2}$. The area shown in figure 7 bounded by the Yucca and Topgallant faults on the east and west, respectively, and subsidence saddles on the north and south is the model area referred to in this report. The three-dimensional model was constructed to include the combined effect of the nearly 30 nuclear tests detonated between 1962 and 1990 on water levels in the bedded tuffs in and near the modeled area (table 3 and fig. 7).

\section{Common Model Approaches and Boundary Conditions}

Water-level changes from detonation effects were simulated independently using the principle of superposition to isolate the effects of natural ground-water flow from flow induced by detonation effects. The assumption of superposition is considered reasonable because ground-water flow through the bedded tuffs is best described by confined-flow conditions. Prior to underground nuclear testing water levels in the bedded tuffs were relatively stable. Recharge to the flow system has been minimal for the last few thousand years. In addition, the water table in the bedded tuffs is less than $50 \mathrm{~m}$ above water levels in the underlying carbonate rock and measured long-term, water-level fluctuations in the carbonate rock are less than $1 \mathrm{~m}$ (Fenelon, 2005). Water-level fluctuations in the underlying carbonate rock are small relative to observed water-level increases of $500 \mathrm{~m}$ in the bedded tuffs caused by underground testing. The superposition approach was applied in the cross-sectional and three-dimensional models which focus on changes imposed on the pretesting flow system.

Observed regional-scale subsidence was attributed solely to elastic compaction and was computed in model simulations from the water released from storage per unit area. Both models simulated small changes in water levels resulting from leakage into the water table. If subsidence results from inelastic compaction or some other nonsimulated process, both models would overestimate the specific storage of the beddedtuff sequence.

The bedded-tuff sequence was simulated as a homogeneous, isotropic unit characterized by a single hydraulic conductivity and specific storage. Available data are inadequate to characterize the hydraulic conductivity of the individual stratigraphic units (Paintbrush Tuff, Grouse Canyon Tuff, and Tunnel Beds) that make up the bedded-tuff sequence because hydraulic tests within the bedded tuffs are few. Vertical-to-horizontal anisotropy is assumed minimal because of the extensive zeolitization of the tuff units (Laczniak and others, 1996).

The surface of the water table is the upper boundary in the cross-sectional and three-dimensional models (fig. 2). Transmissivity of model cells representing the water-table did not vary with water-level change. This approach is considered reasonable because low vertical hydraulic conductivity causes flow in the bedded tuffs to respond as a confined system. A storage coefficient representing a specific yield of 0.2 was assigned to the uppermost row in the cross-sectional model and the uppermost layer in the three-dimensional model. The assigned specific yield was within the range of measured porosities from cores (10-40 percent; Martin and others, 1994, 1995).

The top of the carbonate rock was the lower boundary of both models (fig. 2). Carbonate rock likely was deformed by detonations but any water-level changes in the permeable carbonate rocks dissipated quickly. The carbonate rocks are more permeable than the bedded tuffs by more than four-orders of magnitude (Belcher and others, 2002). The lower boundary was simulated with a specified head of zero because change from the natural flow system was simulated with superposition. The Topgallant and Yucca faults constitute the western and eastern model boundaries, respectively (fig. 2). Most overpressured saturated tuffs along these faults are adjacent to zeolitized, air-fall tuffs opposite the fault and could be interpreted as no-flow boundaries. Alternatively, these faults could serve as conduits to overlying welded tuffs and underlying carbonate rock. These two faults were simulated as generalhead boundaries with a specified head of zero. The hydrologic significance of these faults was investigated by varying conductance between the overpressured tuffs and general-head boundaries over several orders of magnitude. 
Table 3. Underground nuclear tests in or near the overpressured area of central Yucca Flat

[Source is U.S. Department of Energy (1997; 2000). Sites sorted by date of underground nuclear test. Site number is assigned by U.S. Geological Survey to identify drill holes throughout United States. Hole identifier is assigned by U.S. Department of Energy to identify drill holes on Nevada Test Site (NTS). Nuclear-test name is assigned by the U.S. Department of Energy to identify nuclear tests detonated on NTS. Test locations shown as red circles in figure 1 . Negative depth indicates test location above water table]

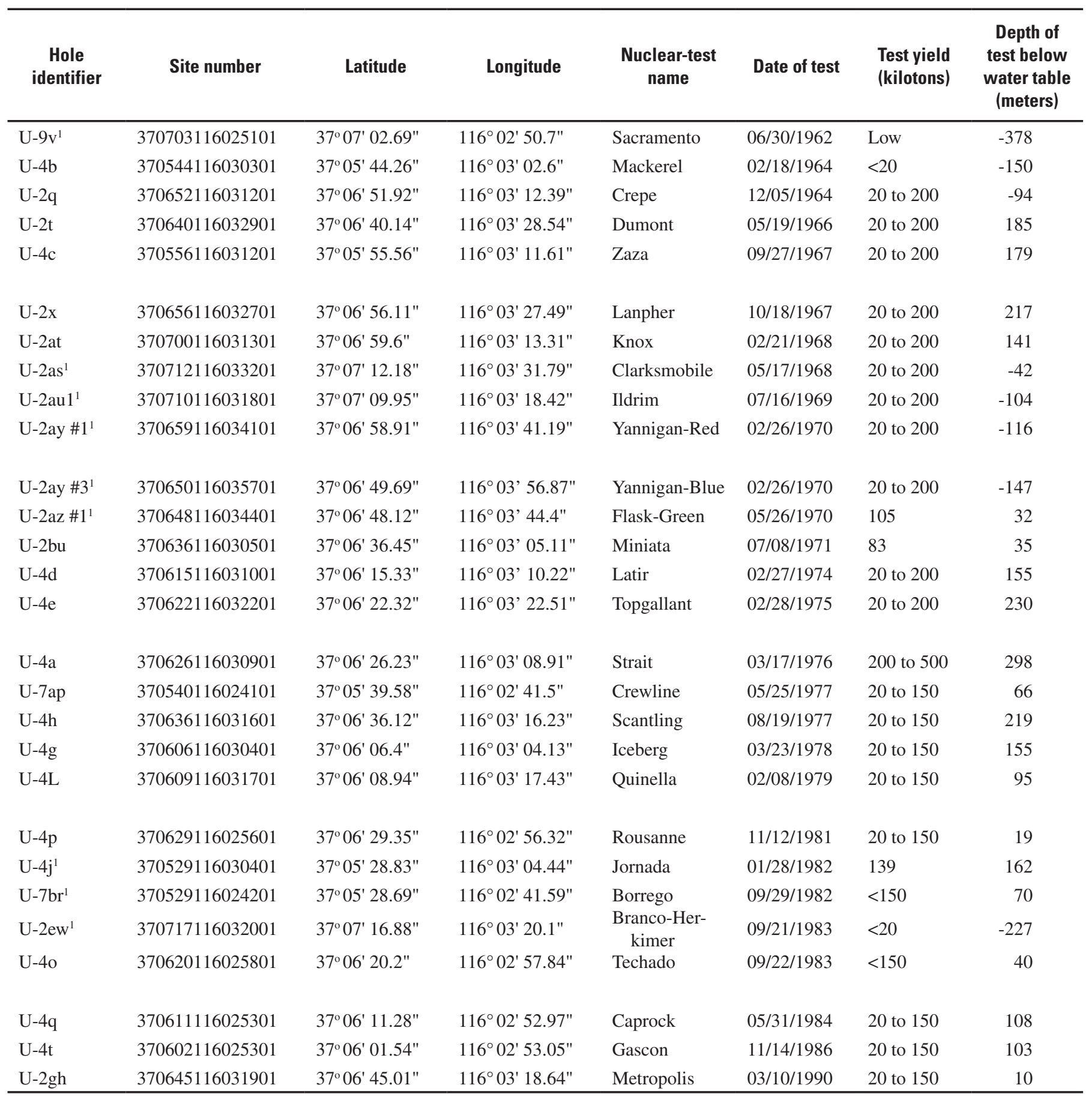

${ }^{1}$ Nuclear test detonated outside model area shown in figure 7. 


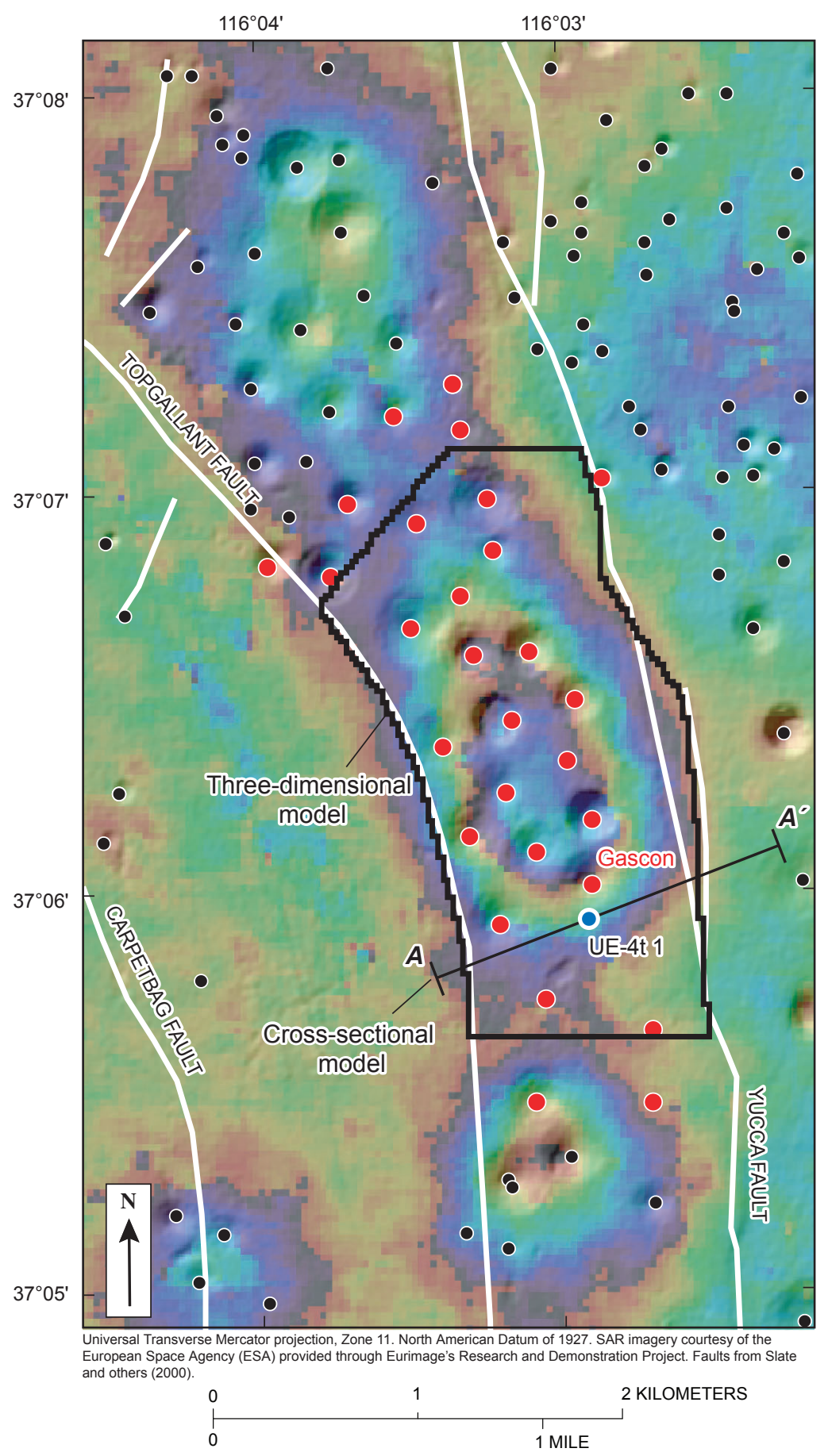

\section{EXPLANATION}

Relative range displacement

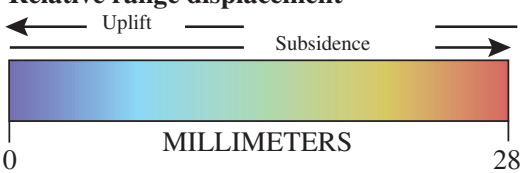

UE-4t $1 \bullet$ Well and hole identifier

Underground nuclear test-U.S. Department of Energy (2000)

- Simulated in three-dimensional model

- Not simulated in three-dimensional model

Figure 7. Location of cross-sectional and three-dimensional models used to estimate hydraulic properties of bedded tuffs in overpressured area of central Yucca Flat.

Base interferograms depicts subsidence occurring between June 18, 1993, and June 11, 1995. 


\section{Cross-Sectional Model}

The cross-sectional model passes through well UE-4t 1 and transects the Topgallant-Yucca fault block (fig. 2). This transect is perpendicular to the major axis of the subsidence trough in central Yucca Flat (figs. 4 and 7). The cross-sectional model was constructed using a grid of 60 rows in the vertical direction and 125 columns in the horizontal direction. Each model cell measures $10 \mathrm{~m}$ by $10 \mathrm{~m}$. Active model cells include bedded, air-fall tuff below the water table. About 40 percent of the 7,500 model cells are inactive because of the westward dip of the carbonate-rock unit (fig. 2).

No nuclear-test-generated cavities were simulated in the cross-sectional model. A cavity simulated in the cross section creates a perpendicular trench-like feature. Preliminary model runs did not simulate subsidence accurately because a trenchlike feature poorly approximates the cylindrical cavity. The cumulative effect of individual detonations was simulated by imposing an initial-head distribution that represented increases in water level induced by nearby nuclear testing.

The time period for model simulation began November 14,1986 , the date of the last detonation within $0.5 \mathrm{~km}$ of the cross-section profile (fig. 7). A 18-year period ending in 2004 was simulated with a single stress period inclusive of all subsidence and water-level observations (fig. 8). The model was calibrated by comparing simulated to observed water levels in well UE-4t 1 between August 19, 1993, and September 10, 2003, and subsidence between April 24, 1992, and June 16, 1997.

\section{Initial-Head Distribution}

The cumulative effects of 22 years of nuclear testing within $0.5 \mathrm{~km}$ of the trace of the model cross section defined the initial-head distribution used for cross-sectional simulation (fig. 9). The magnitude of water-level rise associated with the many nearby tests is unknown but was estimated during model calibration. The lateral shape of the initial-head distribution was assumed proportional to that of the subsidence measured, and the vertical shape was assumed to decrease linearly away from the average depth of all nuclear tests detonated near the cross section.

The initial head distribution is defined by the equation:

$$
H I_{i, j}=\left(A * H S F_{i}\right)+\left(B * V S F_{j}\right)+C
$$

where:

$\mathrm{HI}_{i, j}$ is initial head that varies with column index $i$ and row index $j$,

$A$ is a multiplier,

$H_{S F}$ is a horizontal shape function that varies with column index $i$,

$\mathrm{B}$ is a multiplier,

$V S F_{j}$ is a vertical shape function that varies with row index $j$, and

$C$ is a constant.

The horizontal shape function (HSF) reproduces the shape of subsidence measured between April 24, 1992, and June 16, 1997, along the cross section and varies between zero and one (fig. 9). The vertical shape function (VSF) decreases symmetrically about the average depth of all nuclear tests detonated near the cross section. The function ranges from

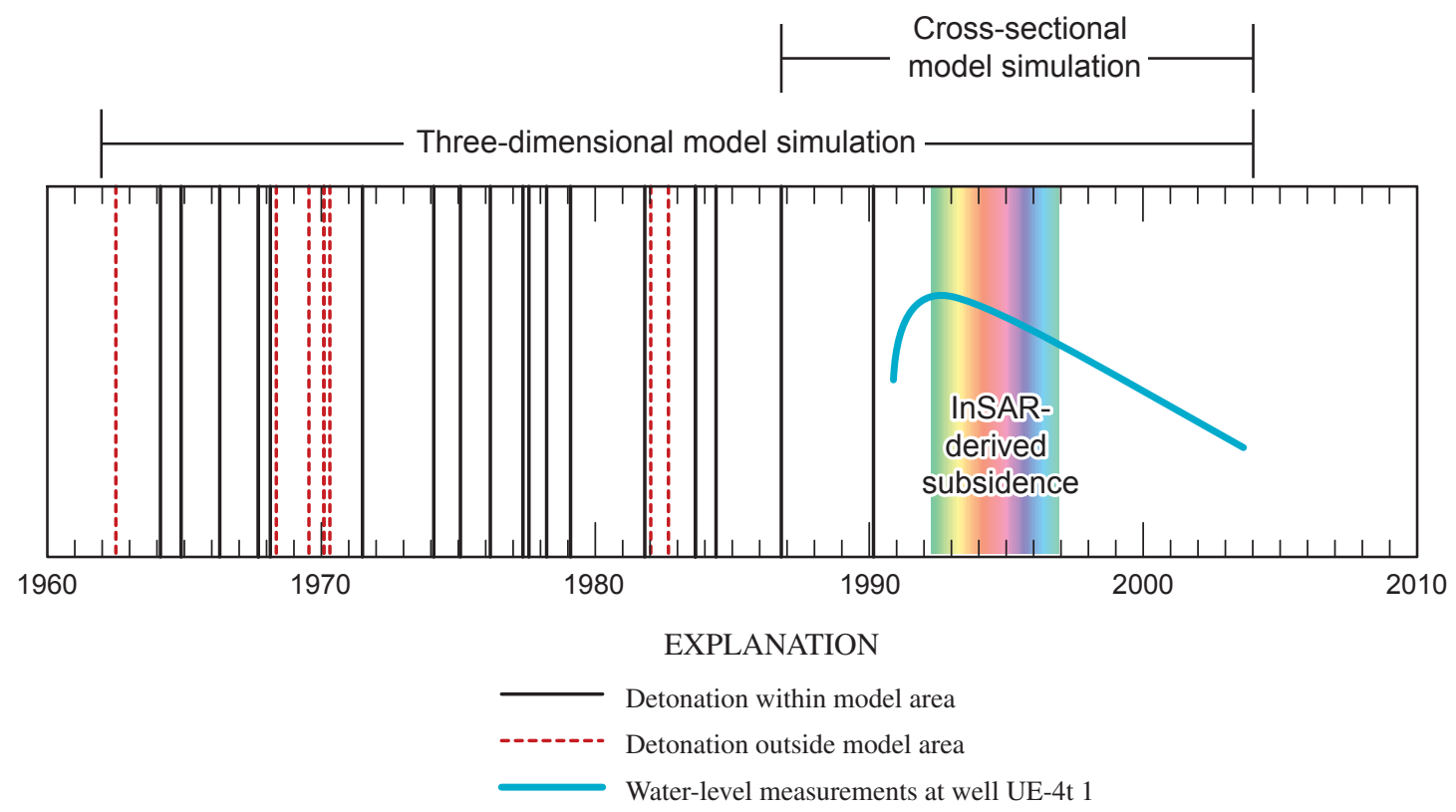

Figure 8. Time line showing water-level and subsidence measurements used as observations to calibrate cross-sectional and three-dimensional models, and detonations used to develop three-dimensional model. 


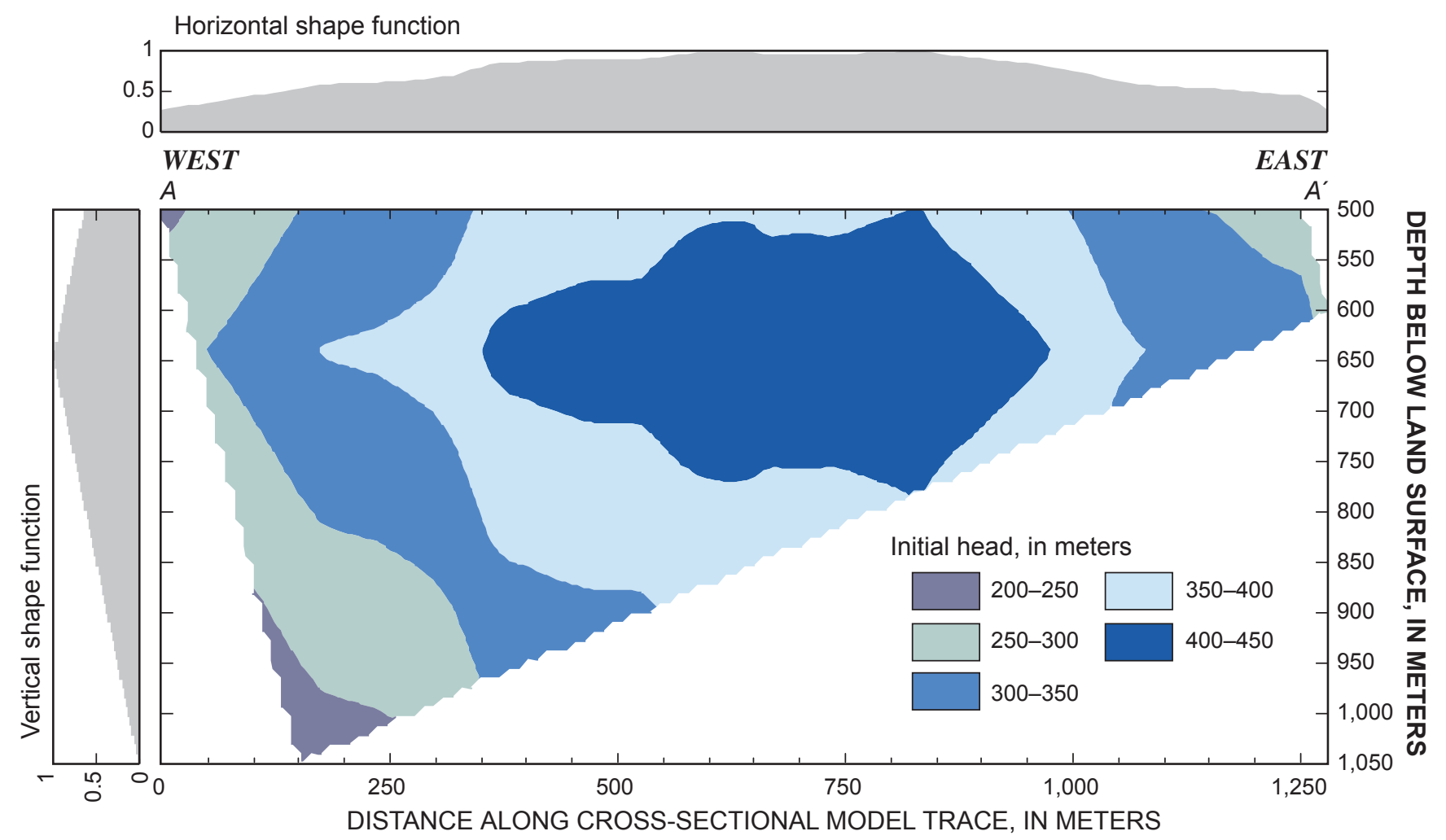

Figure 9. Initial-head distribution estimated for model simulation using horizontal and vertical shape functions developed for cross-sectional model.

zero to one between 1,050 and $650 \mathrm{~m}$ below land surface (fig. 9). Coefficients A, B, and C were estimated during model calibration.

\section{Model Calibration}

The cross-sectional model was calibrated to water-level and subsidence-rate observations. Simulated heads were calibrated to water-level measurements made in well UE-4t 1 after 1992. Subsidence rates along the cross-section trace were computed from the three time-sequenced interferograms (fig. 4). Computed rates were assigned to the central date within the time period spanned by interferograms and were sampled at 20-m intervals along the cross section for comparison with model simulated values. Subsidence was simulated by the release of water from storage in an entire model column (Leake and Prudic, 1991), which extends from the water table to the top of carbonate rock.

Differences between simulated and measured water-level and subsidence-rate observations were minimized during model calibration using a weighted, sum-of-squares objective function. Observations were weighted such that both observation types (water level and subsidence) would influence model calibration equally. Weights were estimated iteratively to ensure that the weighted sensitivity of a parameter would not be dominated by any one observation type. Observations within each observation type were weighted uniformly.
Hydraulic conductivity, specific storage, fault conductance, and coefficients (A, B, and C) of each shape function were estimated during model calibration (table 4).

A normalized, composite-scaled sensitivity (Hill, 1998), herein referred to as a relative sensitivity, was used to evaluate parameter sensitivity. The relative sensitivity of a parameter is its composite-scaled sensitivity divided by the maximum composite-scaled sensitivity. The most sensitive parameter has a relative sensitivity of 1 .

Observed and simulated water levels are compared in figure 10. A good comparison is exemplified by a small rootmean-square (RMS) error of $0.3 \mathrm{~m}$ relative to about $60 \mathrm{~m}$ of water-level change. A good fit to a single hydrograph indicates only that the hydraulic diffusivity around the observation is well constrained. Hydraulic diffusivity (hydraulic conductivity divided by the specific storage) of the overpressured tuff was estimated to be $0.5 \mathrm{~m}^{2} / \mathrm{d}$ near well UE-4t 1 by the crosssectional model.

Observed and simulated subsidence between April 24, 1992, and June 16, 1997, averaged 53 and $55 \mathrm{~mm}$, respectively (fig. 11). Local differences near the western edge and consistent overestimation near the eastern edge caused the root-mean-square (RMS) error $(8 \mathrm{~mm})$ to be greater than the average error ( $2 \mathrm{~mm}$ ). These consistent errors likely result from the fixed geometries of the shape functions that skewed estimates of the initial-head distribution (fig. 9). 
Table 4. Shape functions and hydraulic-property parameters estimated or evaluated by cross-sectional model

\begin{tabular}{lcc}
\hline \multicolumn{1}{c}{ Model parameter and units } & $\begin{array}{c}\text { Parameter } \\
\text { value }^{1}\end{array}$ & $\begin{array}{c}\text { Relative } \\
\text { sensitivity }\end{array}$ \\
\hline Hydraulic conductivity of overpressured tuff, meters per day & $\underline{3 \times 10^{-6}}$ & 0.360 \\
Specific storage of overpressured tuff, m-1 & $\underline{6 \times 10^{-6}}$ & 0.370 \\
Specific yield of water table, dimensionless & 0.2 & - \\
Conductance of interface between overpressured tuffs and boundary faults, square meters per day & $\underline{3 \times 10^{-8}}$ & 0.003 \\
Shape function constant (C), meters & $\underline{120}$ & 1.000 \\
Horizontal shape function multiplier (A), meters & $\underline{220}$ & 0.960 \\
Vertical shape function multiplier (B), meters & $\underline{100}$ & 0.880 \\
\hline
\end{tabular}

${ }^{1}$ Underlined parameter values estimated by model. Parameter values not underlined assigned after being evaluated by multiple model simulations.

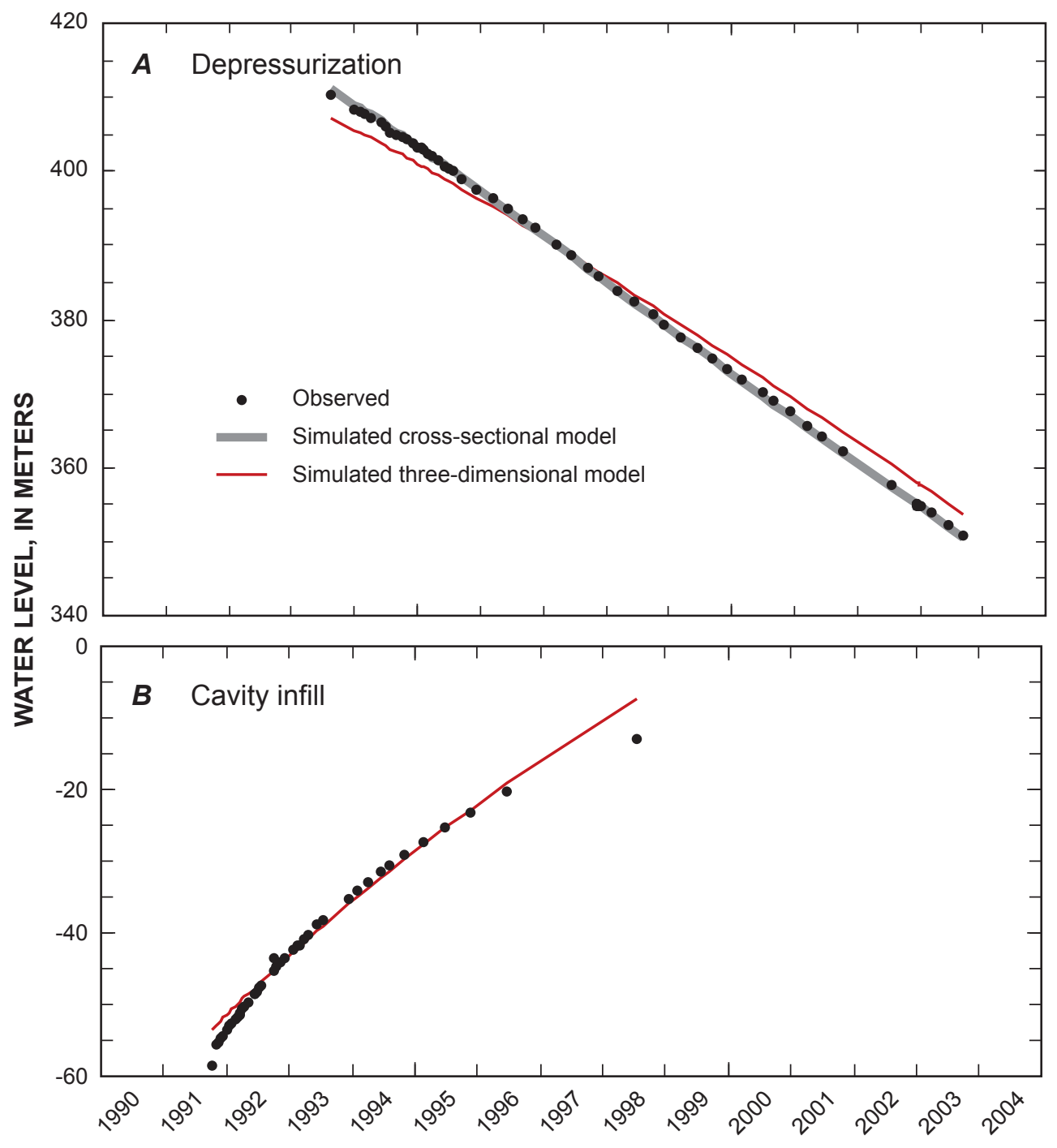

Figure 10. Comparison of observed water levels and water levels simulated with cross-sectional and three-dimensional models at: (A) at UE-4t 1 and (B) U-4u PS 2A. Well locations shown in figure 1. 


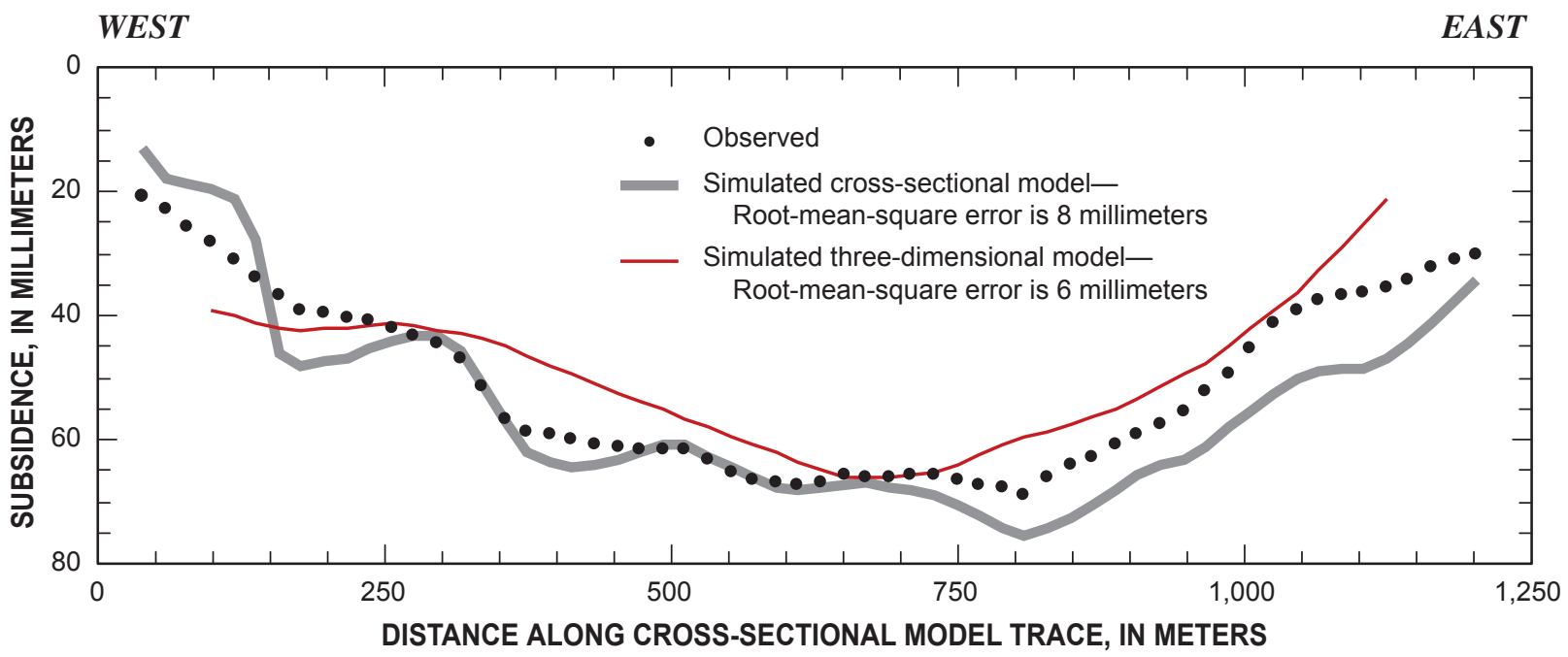

Figure 11. Comparison between observed subsidence and subsidence simulated with cross-sectional and three-dimensional models along cross-sectional model trace, April 24, 1992-June 16, 1997.

Cross-sectional model trace shown in figure 7.

\section{Model Results}

A hydraulic conductivity of $3 \times 10^{-6} \mathrm{~m} / \mathrm{d}$ was estimated by the cross-sectional model (table 4 ). This estimate is about 10 times less than the geometric mean of the slug-test results (table 1) and is about 10 times greater than the minimum hydraulic-conductivity estimate. The model estimated hydraulic properties likely are more representative than the slugtest results because unlike the slug tests, hydraulic-property estimates from the cross-sectional model were not affected by well construction, and because the cross-sectional model simulates responses from a much greater volume of tuffs.

A specific storage of $6 \times 10^{-6} \mathrm{~m}^{-1}$ was estimated by the cross-sectional model (table 4) and was constrained primarily by subsidence measurements. The specific storage estimated from the cross-sectional model agrees with an estimate $4 \times 10^{-6}$ $\mathrm{m}^{-1}$ made using a simple volumetric calculation. If observed subsidence is caused by inelastic compaction or by some process other than depressurizing of the bedded tuffs, the specific storage would be less than that estimated by the model.

All parameters, except fault conductance, significantly affected model calibration (table 4 ). The coefficients that defined the initial-head distribution had the greatest relative sensitivities and affected model results more than hydraulic properties. This is likely an artifact of the distribution of weights between water-level and subsidence observations. About half of the initial rise in water level was simulated by the horizontal shape function. The vertical shape function least influenced the initial water-level rise but was significant to model calibration (table 4).

The Topgallant and Yucca faults likely restrict groundwater movement because the conductance estimated across the faults was small (table 4). A conductance of $3 \times 10^{-8} \mathrm{~m}^{2} / \mathrm{d}$ also can be interpreted as a hydraulic conductivity of $3 \times 10^{-7} \mathrm{~m} / \mathrm{d}$ if the distance between general head and model node is assumed to be a cell length of $10 \mathrm{~m}$. The faults function as nearly impermeable boundaries if the hydraulic conductivity across the fault is two-orders of magnitude less than the overpressured tuff. The small estimated conductance of the interface between the faults and the overpressured tuff could be a consequence of overestimated initial heads along the western edge of the model.

\section{Three-Dimensional Model}

The active, three-dimensional model grid covers an area of about $5 \mathrm{~km}^{2}$. The model was constructed using 20 layers of 109 rows and 76 columns (fig. 12). Each model cell measures $25 \mathrm{~m}$ on a side. The contact between the overpressured tuff and Paleozoic carbonate forms the base of the model. This contact is a planar surface striking $14^{\circ}$ west of north and dipping $20^{\circ}$ west-southwest. More than 60 percent of the 165,680 model cells are inactive because the westward dip of the carbonate-rock unit truncates the overpressured tuff between layers 4 and 20 .

The northern and southern boundaries of the three-dimensional model coincide with saddles in the subsidence surface (fig. 4). Head distributions are assumed to be shaped similar to subsidence distributions. This conceptualization suggests that the northern and southern boundaries can be simulated as no-flow boundaries. All other boundary conditions for the three-dimensional model were similar to those described for the cross-sectional model.

The cumulative effect of 28 nuclear-device detonations within and near the overpressured area is best simulated with a three-dimensional model. The U.S. Department of Energy (2000) reports the depth and yield associated with each of these nuclear tests. Tests in the study area were detonated between 1962 and 1990 (fig. 8). Only about 10 percent of these tests have reported yields less than $20 \mathrm{kt}$ (table 3 ). 


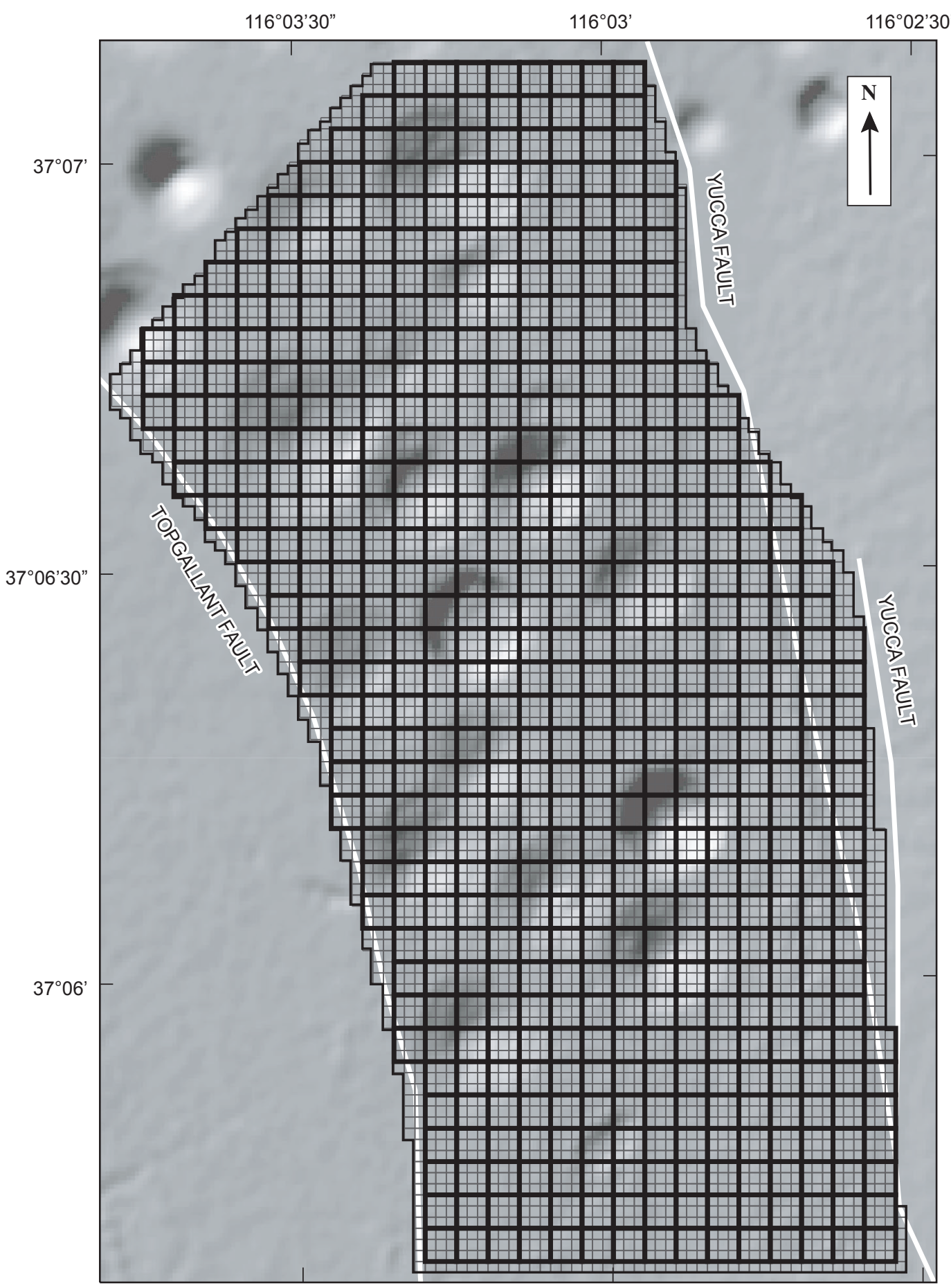

Universal Transverse Mercator projection, Zone 11. North American Datum of 1927. Shaded relief from 10-meter digital elevation model provided courtesy of U.S. Department of Energy's Remote

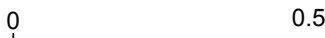

|

0 1 KILOMETER

Faults from Slate and others (2000).

EXPLANATION

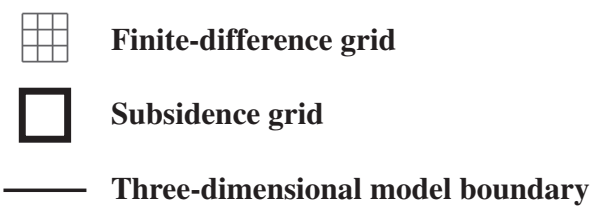

Figure 12. Finite-difference grid, lateral model boundaries, and grid used for subsidence-rate observations. 
A 42-year period was simulated with 29 stress periods that coincided with all subsidence and water-level observations (fig. 8). Model simulation began on January 1, 1962, 6 months before the first detonation on June 30, 1962 (table 2). Water levels were compared between August 1, 1993, and September 9, 2003, in well UE-4t 1. Subsidence between April 24, 1992, and June 16, 1997, was compared. Simulated and observed subsidence rates were averaged over nine model cells to suppress measurement noise (fig. 12). Subsidence rates were compared only in areas where nine model cells were present.

\section{Simulation of Detonation Effects}

Detonation effects were simulated as spherical, instantaneous rises in water level. Maximum water-level rise occurred at the cavity wall, around the detonation. Water-level rises were negligible beyond an assumed radius of alteration. Radii of $400,500,600,700,800$, and 1,000 m were investigated through model simulation. A uniform radius of alteration and water-level rise function were assigned for each model simulation.

Instantaneous rises in water level were simulated in MODFLOW using a modified version of the Time-Variant Specified Head (CHD) package (Leake and Prudic, 1991). A step change in head was specified independently for each active cell. Any computed instantaneous water-level rise was added to simulated heads at the beginning of each stress period for cells affected by a nuclear detonation. These cells were not converted to specified-head boundary conditions after simulated heads were raised.

Water-level rises were defined by multiplying a maximum water-level rise times a spherical shape function for each detonation. Each shape function ranged from one at the detonation to zero at the radius of alteration. Spherical shape functions were truncated at the model boundaries for consistency with the conceptual model of rapid dissipation of water-level changes through more permeable rocks. The maximum water-level rise for each detonation was estimated during model calibration.

Water-level rise between the radius of alteration and detonation was defined with linear and cube-root functions (fig. 13). Linear functions were used because of their simplicity. Cube-root functions better described the expected decay of energy away from a detonation (Wohletz and others, 1999).

\section{Model Calibration}

In addition to observations used to calibrate the crosssectional model, the three-dimensional model was calibrated to water-level change in a cavity and subsidence rates across the entire model area. Water-level changes in cavities were presumed similar to those observed in well U-4u PS 2A, which penetrates a cavity south of the model area (fig. 1). The specific yield and initial, post-detonation water level of all cavities were assumed equal throughout the model domain. A specific yield of 0.05 was assigned to each cavity and the

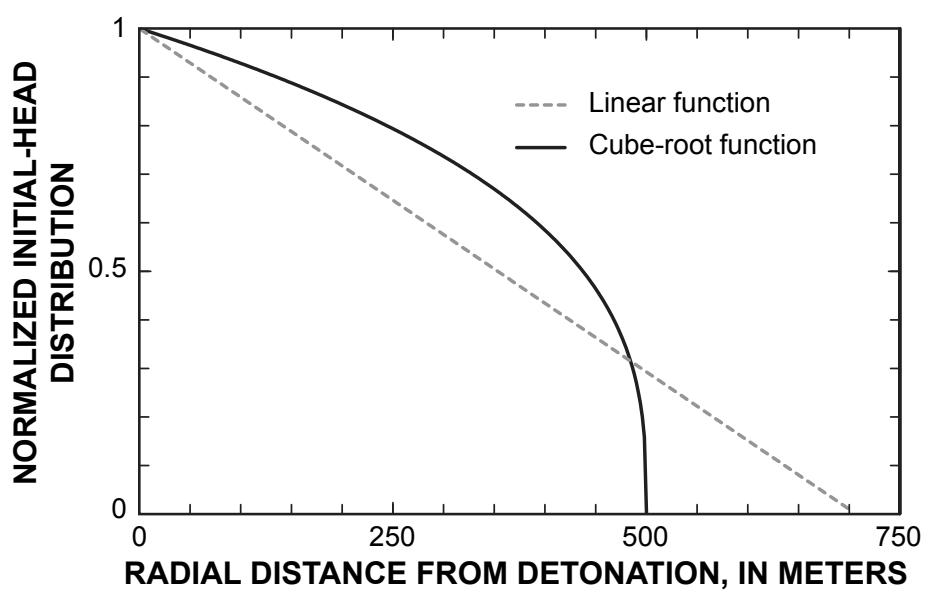

Figure 13. Normalized linear and cube-root functions used to simulate initial hydraulic head increases at and away from a nuclear detonation.

initial, post-detonation water level was estimated during model calibration. The specific yield was not estimated because it was highly correlated with initial, post-detonation water levels in cavities.

Subsidence rates were compared at 564 cells in a coarse grid where each subsidence cell coincided with nine simulation cells (fig. 12). Averaging subsidence estimates across a coarser grid reduced measurement noise. Comparisons were not made along the edge of the model where the comparison grid did not cover nine active model cells. Subsidence rates were assigned to the central date within the time period spanned by the interferograms as was done for the cross-sectional model.

Water-level and subsidence observations were weighted such that they both equally influenced model calibration. Weighted, parameter sensitivities were calculated and subsidence weights were adjusted such that the sums of weighted, parameter sensitivities for the two observation types were about equal. Subsidence weights were evaluated iteratively as model calibration altered the sums of weighted, parameter sensitivities. Observations within each observation type were weighted uniformly. Hydraulic conductivity, specific storage, fault conductance, post-detonation water levels in cavities, and water-level rise for each detonation were estimated during model calibration (table 5).

Twelve alternative three-dimensional models were tested with assigned radius-of-alteration and water-level increase functions. Radii of 400, 500, 600, 700, 800, and 1,000 m were investigated. Linear and cube-root water-level, increase functions were tested. The model with a 700-m radius of alteration and linear water-level rise function best simulated observed water levels (fig. 10) and subsidence rates (figs. 11 and 14). Simulated and measured subsidence rates between 1992 and 1997 were similar with few systematic biases (fig. 14). The apparent temporal bias between the 1993-95 and 1995-97 subsidence rates could have resulted from an overestimation 


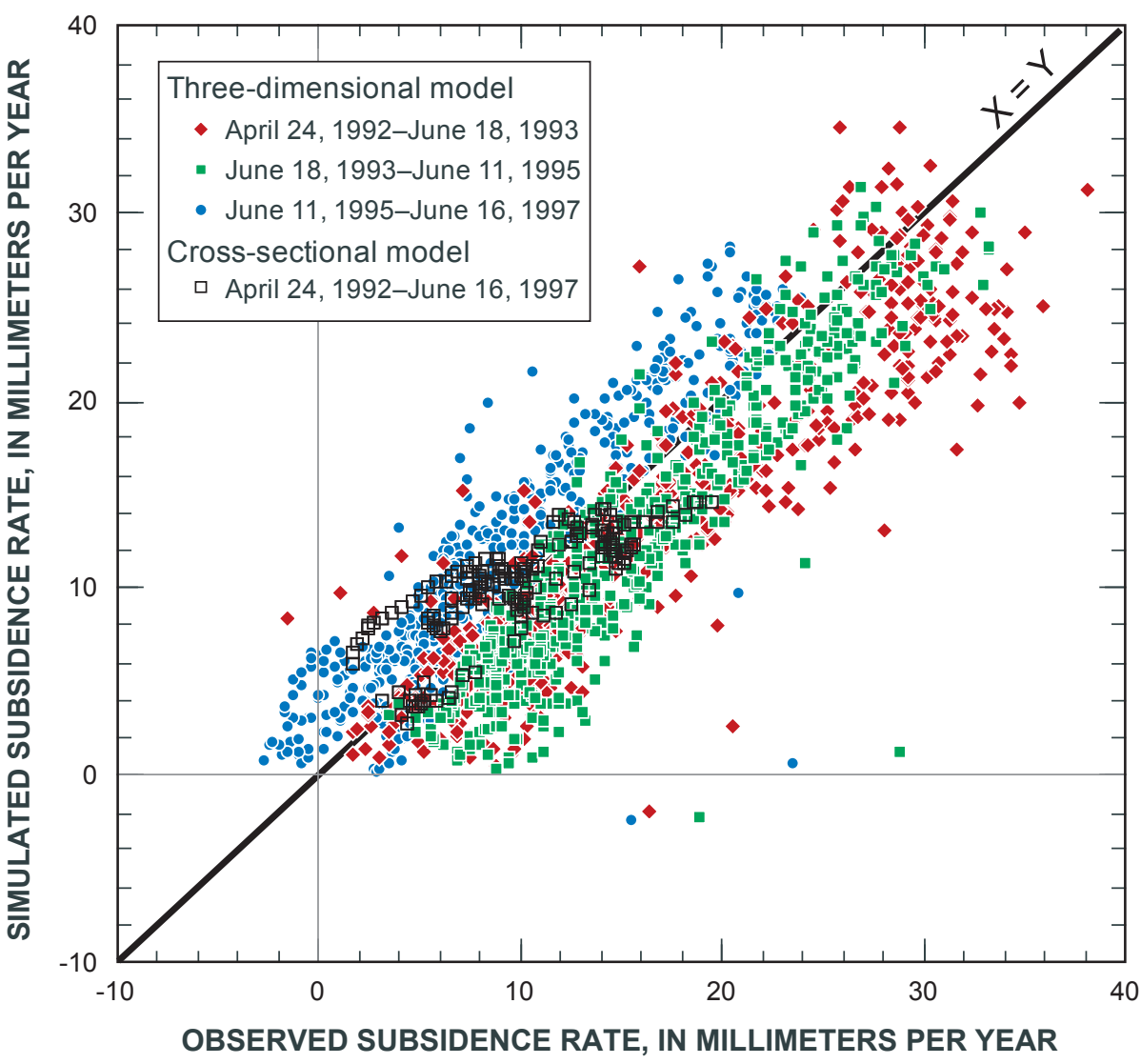

Figure 14. Comparison of observed subsidence rates and subsidence rates simulated with cross-sectional and three-dimensional models for different time periods between April 24, 1992, and June 16, 1997.

of subsidence in the shared image (June 8, 1993-June 1, 1995; fig. 4). An alternative model with a 600-m radius of alteration and cube-root, water-level rise function yielded similar results but had a 25 percent larger sum-of-squares error.

Simulated and measured subsidence between April 24, 1992, and June 16, 1997, compared well (fig. 15) averaging 64 and $70 \mathrm{~mm}$, respectively, over the model area. About 50 percent of the simulated values were within $10 \mathrm{~mm}$ of InSAR measurements. Observed subsidence exceeded simulated subsidence by more than $50 \mathrm{~mm}$ over less than 1 percent of the model area. The largest differences occurred near detonation cavities and along lateral model boundaries (fig. 15).

Hydraulic-property estimates were insensitive to the radius of alteration and the water-level rise function. Regardless of the radii or rise function used in the simulation, the hydraulic conductivity always was estimated at about $3 \mathrm{x}$ $10^{-6} \mathrm{~m} / \mathrm{d}$ and specific storage at about $9 \times 10^{-6} \mathrm{~m}^{-1}$ (table 5). Equivalent hydraulic properties estimated by the many different simulations differed by less than 10 percent.

\section{Model Results}

Simulated water-level change between April 24, 1992, and June 16, 1997, generally coincided with subsidence (figs. 15 and 16). Slight differences in water-level change in a layer existed partly because of the dipping contact with the carbonate-rock aquifer. Detonation depths that ranged from $400 \mathrm{~m}$ above the water table to $300 \mathrm{~m}$ below the water table caused water-level changes to vary with depth. Detonation of the Topgallant test in drill hole U-4e created a water-levelchange lobe extending more than 900 $\mathrm{m}$ below land surface (fig. 16B).

Simulated water levels rose more than $750 \mathrm{~m}$ between 1962 and 1987 because of the cumulative effect of detonations (fig. 17). Maximum waterlevel rise was coincident with a cavity and surrounded by six other detonations within $700 \mathrm{~m}$. These detonations occurred over a 20 -year period.

Cumulative discharges to the water table and carbonate rock were equal in 2005 (fig. 18). Cumulative discharges differed by 10 percent immediately after individual detonations, but these differences diminish after about 10 years. Upward discharge has elevated the water table by more than 2 $\mathrm{m}$ near the middle observation.

Individual detonations clearly affected ground-water levels throughout the modeled area (fig. 18). The "middle" hydrograph in figure 18 shows eleven discrete water-level rises in model layer 8 attributed to detonations simulated in the three-dimensional model. These waterlevel rises ranged between 20 and $200 \mathrm{~m}$. Fewer discrete water-level rises appeared in the "north" and "south" hydrographs of figure 18 because few detonations were within 700 $\mathrm{m}$ of the north and south locations.

Only about 50 percent of the simulated ultimate discharge and subsidence attributed to the effects of nuclear detonations occurs by 2005 (fig. 19). Since the cessation of testing, simulated discharge and water levels decrease exponentially such that 92 and 99 percent of the ultimate discharge occur by 2200 and 2400, respectively. Water levels simulated within the tuffs remained higher than the water table beyond 2400 .

Water-level changes of more than $750 \mathrm{~m}$, although dramatic, resulted in relatively little movement of water. Dramatic water-level rises occurred because rock with a specific storage of $9 \times 10^{-6} \mathrm{~m}^{-1}$ has little compressibility. A water-level increase of more than $1,000 \mathrm{~m}$ occurs with a porosity reduction of less than 1 percent.

Based on model simulation, only about 2 million $\mathrm{m}^{3}$ of ground water will flow across the contact between bedded tuff and carbonate rock due to the cumulative effects of nuclear testing. Discharge rates to the carbonate rock averaged 0.008 $\mathrm{m} / \mathrm{yr}$ and did not exceed $0.06 \mathrm{~m} / \mathrm{yr}$ between 1962 and 2005 . 


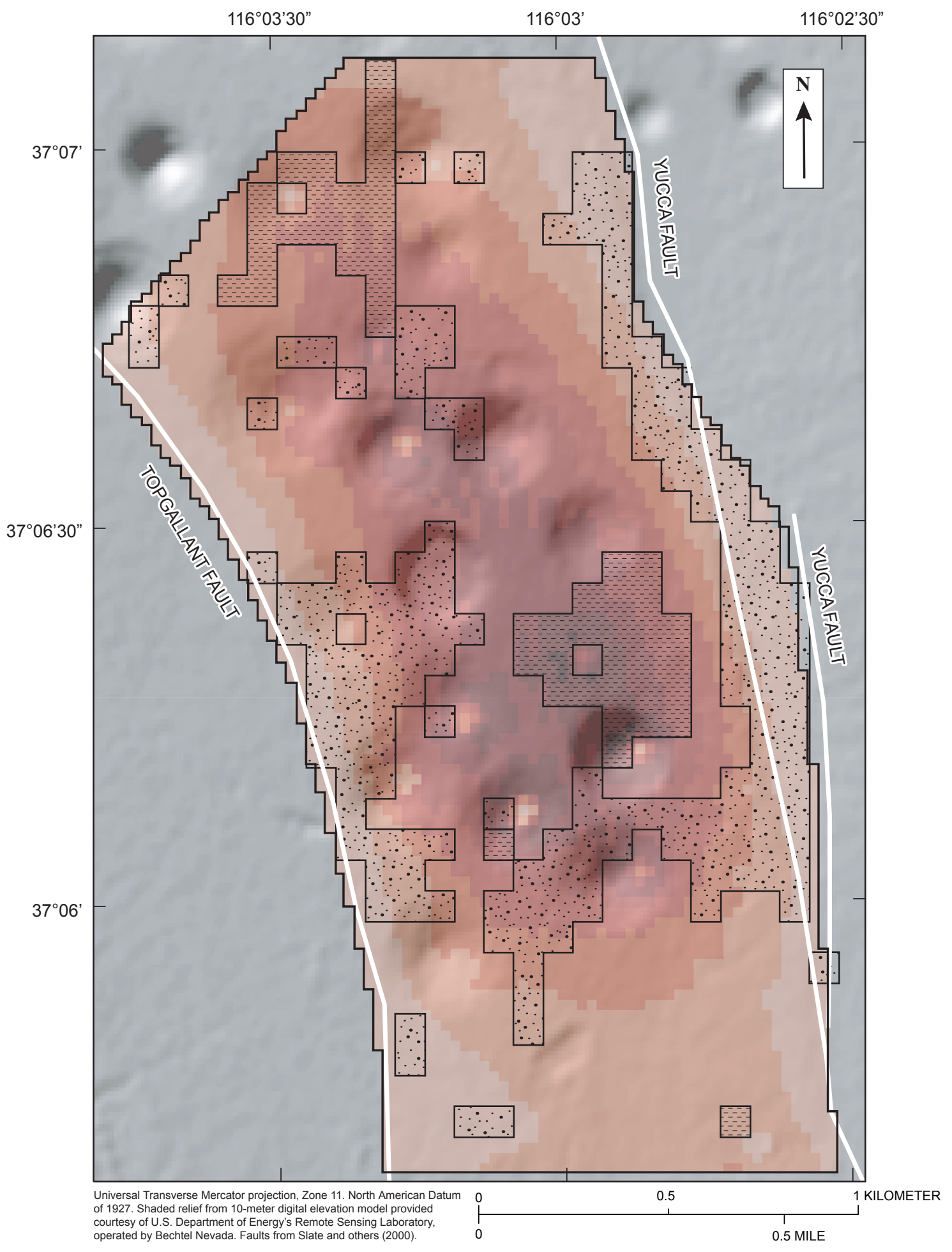

EXPLANATION

Simulated subsidence—-In millimeters

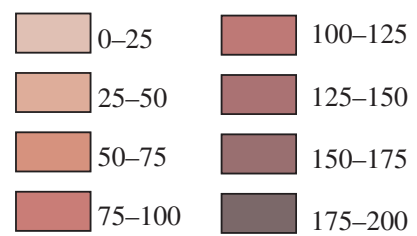

Areas of greatest difference between observed and simulated subsidence (greater than or equal to 10 millimeters)

Measured $>$ simulated

Simulated $>$ measured

Three-dimensional model boundary

Figure 15. Simulated subsidence and general areas of greatest difference between simulated and measured values for period April 24, 1992-June 16, 1997. 
Table 5. Initial-rise and hydraulic-property parameters estimated or evaluated by three-dimensional model

[Initial-rise parameters sorted by date of nuclear test. Year nuclear test detonated given in parentheses in model parameter column. Location of nuclear test is listed in table 3 and shown in figure 7]

\begin{tabular}{|c|c|c|}
\hline Model parameter and units & $\begin{array}{c}\text { Parameter } \\
\text { value }^{1}\end{array}$ & $\begin{array}{c}\text { Relative } \\
\text { sensitivity }\end{array}$ \\
\hline Hydraulic conductivity of overpressured tuff, meter per day & $\underline{3 \times 10^{-6}}$ & 0.20 \\
\hline Specific storage of overpressured tuff, per meter & $\underline{9 \times 10^{-6}}$ & 0.19 \\
\hline Initial decline in cavity, meters & -120 & 0.27 \\
\hline Specific yield of water table, dimensionless & 0.2 & 0.00 \\
\hline Specific yield of cavity, dimensionless & 0.05 & 0.10 \\
\hline Conductance of interface between overpressured tuff and boundary faults, square meters per pay & $1 \times 10^{-7}$ & 0.00 \\
\hline Initial rise of water level in overpressured tuff at U-9v (1962), meters & 50 & 0.01 \\
\hline Initial rise of water level in overpressured tuff at U-4b (1964), meters & $\underline{50}$ & 0.42 \\
\hline Initial rise of water level in overpressured tuff at U-2q (1964), meters & $\underline{210}$ & 0.04 \\
\hline Initial rise of water level in overpressured tuff at U-2t (1966), meters & $\underline{90}$ & 0.05 \\
\hline Initial rise of water level in overpressured tuff at U-4c (1967), meters & $\underline{160}$ & 0.42 \\
\hline Initial rise of water level in overpressured tuff at U-2x (1967), meters & $\underline{100}$ & 0.04 \\
\hline Initial rise of water level in overpressured tuff at U-2at (1968), meters & $\underline{150}$ & 0.05 \\
\hline Initial rise of water level in overpressured tuff at U-2as (1968), meters & 170 & 0.01 \\
\hline Initial rise of water level in overpressured tuff at U-2au (1969), meters & 170 & 0.02 \\
\hline Initial rise of water level in overpressured tuff at U-2ay \#3 (1970), meters & $\underline{100}$ & 0.01 \\
\hline Initial rise of water level in overpressured tuff at U-2ay \#1 (1970), meters & 170 & 0.02 \\
\hline Initial rise of water level in overpressured tuff at U-2az \#1 (1970), meters & 170 & 0.03 \\
\hline Initial rise of water level in overpressured tuff at U-2bu (1971), meters & $\underline{300}$ & 0.05 \\
\hline Initial rise of water level in overpressured tuff at U-4d (1974), meters & $\underline{140}$ & 0.07 \\
\hline Initial rise of water level in overpressured tuff at U-4e (1975), meters & $\underline{130}$ & 0.03 \\
\hline Initial rise of water level in overpressured tuff at U-4a (1976), meters & $\underline{240}$ & 0.04 \\
\hline Initial rise of water level in overpressured tuff at U-7ap (1977), meters & $\underline{170}$ & 0.19 \\
\hline Initial rise of water level in overpressured tuff at U-4h (1977), meters & $\underline{230}$ & 0.06 \\
\hline Initial rise of water level in overpressured tuff at U-4g (1978), meters & $\underline{190}$ & 0.43 \\
\hline Initial rise of water level in overpressured tuff at U-4L (1979), meters & 50 & 0.07 \\
\hline Initial rise of water level in overpressured tuff at U-4p (1981), meters & 300 & 0.06 \\
\hline Initial rise of water level in overpressured tuff at $\mathrm{U}-4 \mathrm{j}$ (1982), meters & $\underline{170}$ & 0.02 \\
\hline Initial rise of water level in overpressured tuff at U-7br (1982), meters & $\underline{170}$ & 0.02 \\
\hline Initial rise of water level in overpressured tuff at U-2ew (1983), meters & $\underline{50}$ & 0.01 \\
\hline Initial rise of water level in overpressured tuff at U-4o (1983), meters & 300 & 0.08 \\
\hline Initial rise of water level in overpressured tuff at U-4q (1984), meters & 310 & 0.40 \\
\hline Initial rise of water level in overpressured tuff at U-4t (1986), meters & 210 & 1.00 \\
\hline Initial rise of water level in overpressured tuff at U-2gh (1990), meters & 150 & 0.11 \\
\hline
\end{tabular}

${ }^{1}$ Underlined parameter values estimated by the model. Parameter values not underlined assigned after being evaluated by multiple model simulations. 


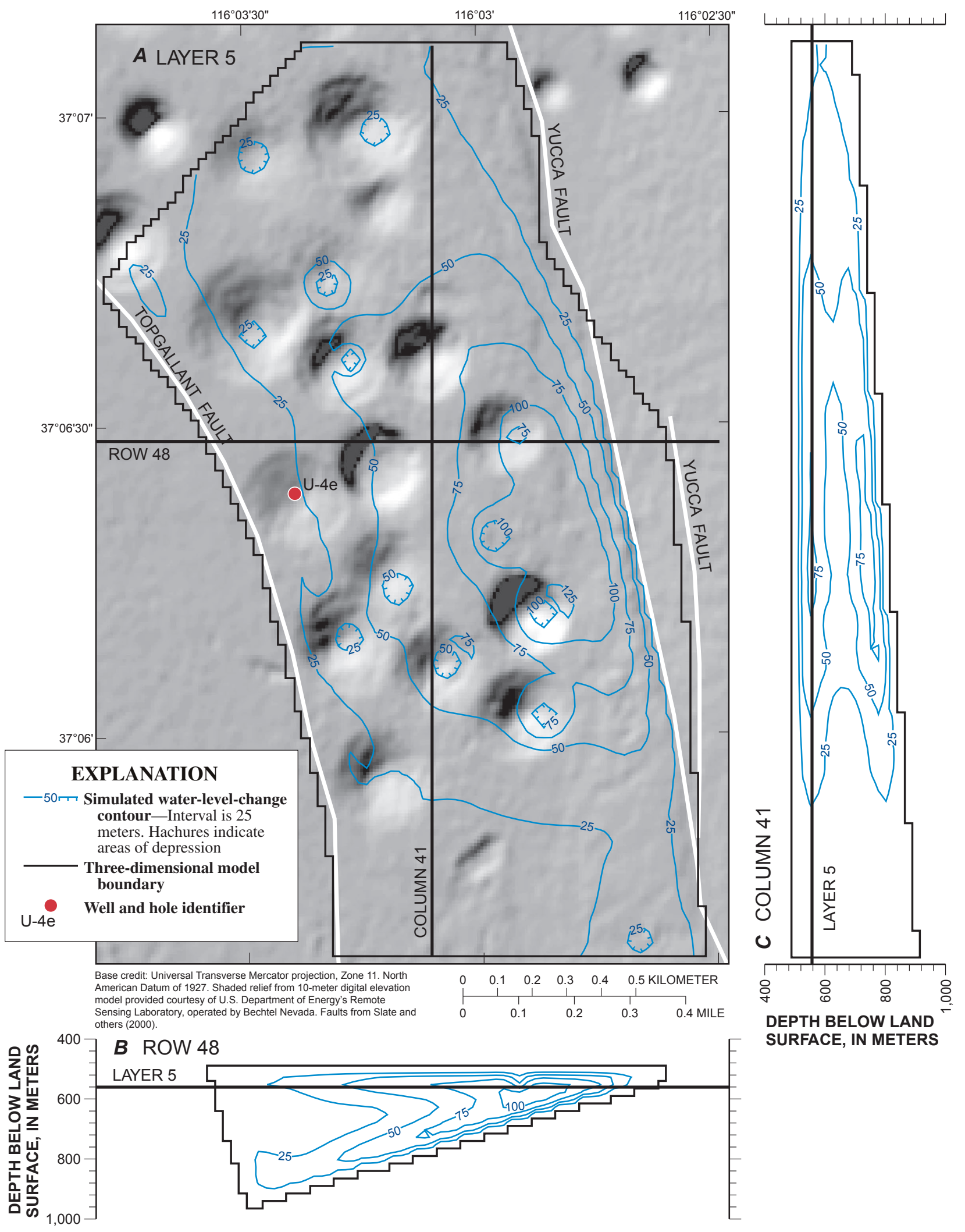

Figure 16. Simulated water-level change for period April 24, 1992-June 16, 1997. (A) model layer 5, (B) across model row 48 , and (C) across model column 41. 


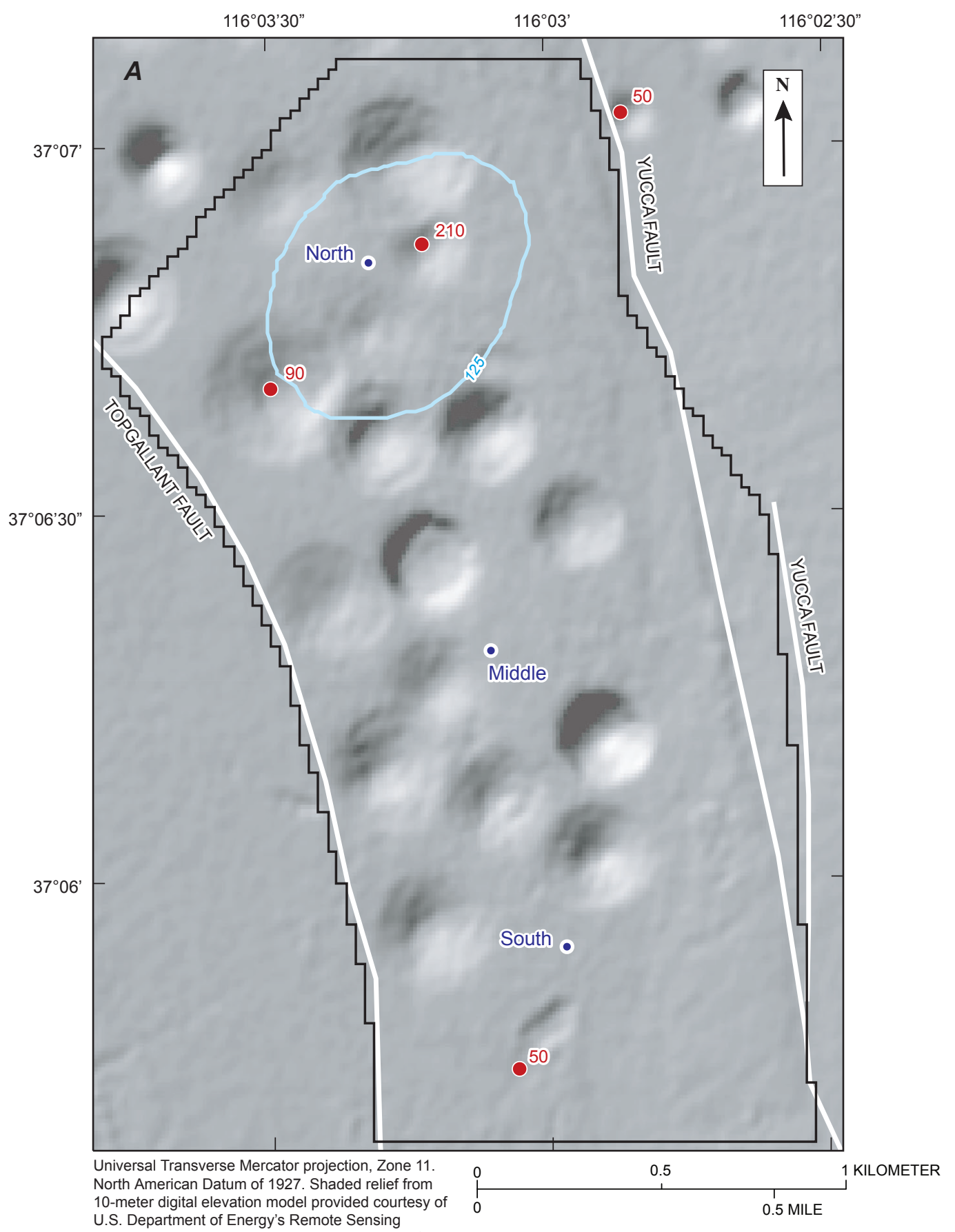

U.S. Department of Energy's Remote Sensing

Laboratory, operated by Bechtel Nevada. Faults from

Slate and others (2000)

\section{EXPLANATION}

Simulated water-level change contourInterval is 250 meters. Supplemental contour is 125 meters

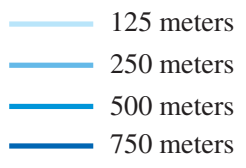

Three-dimensional model boundary

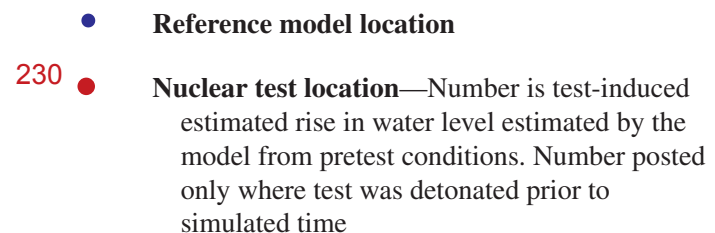

Figure 17. Simulated water-level changes in model layer 5 through (A) March 5, 1967; (B) July 10, 1977; (C) June 28, 1987; and (D) October 23, 1997. 


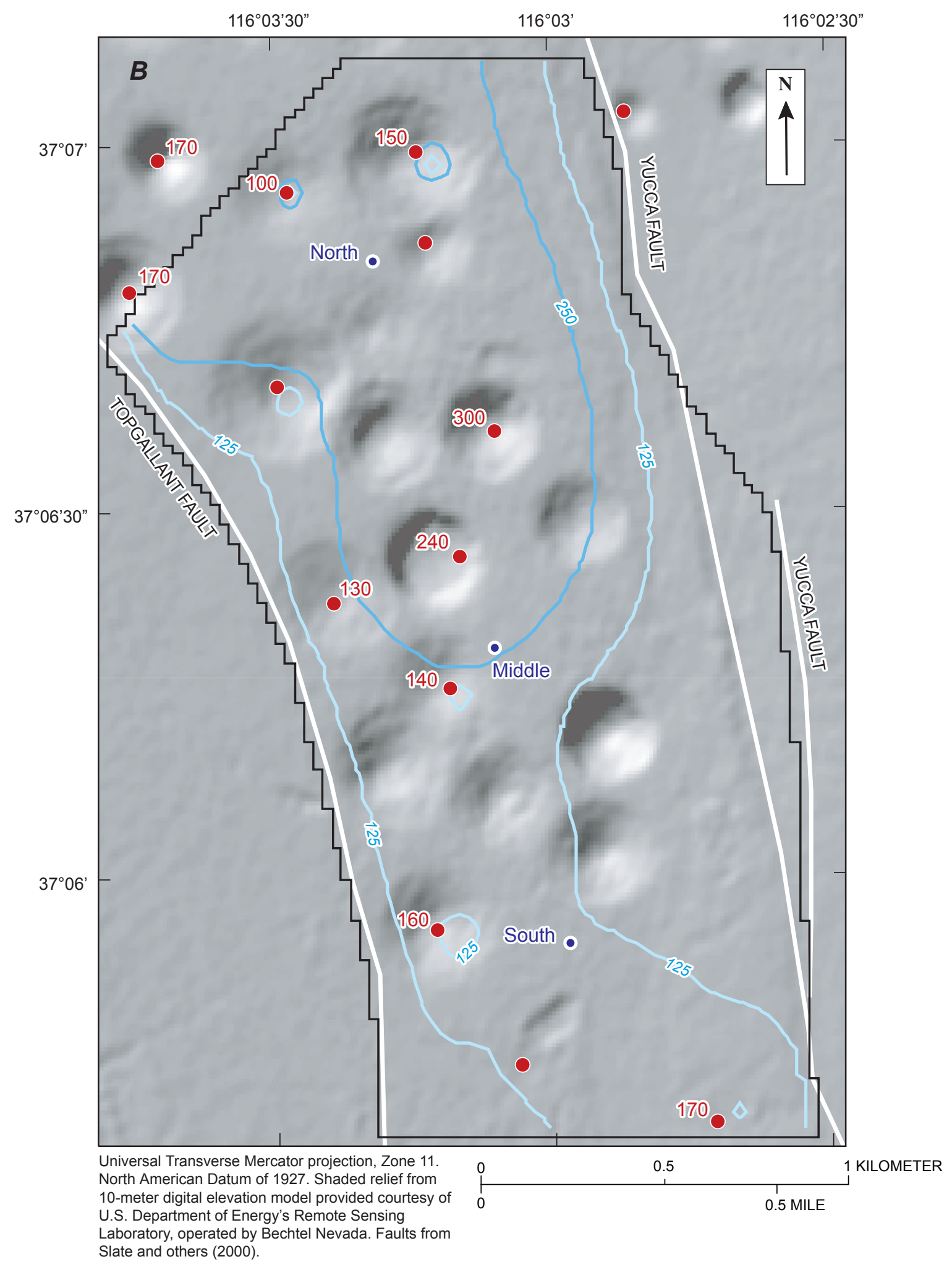

Figure 17. Simulated water-level changes in model layer 5 through (A) March 5, 1967; (B) July 10, 1977; (C) June 28, 1987; and (D) October 23, 1997-Continued. 


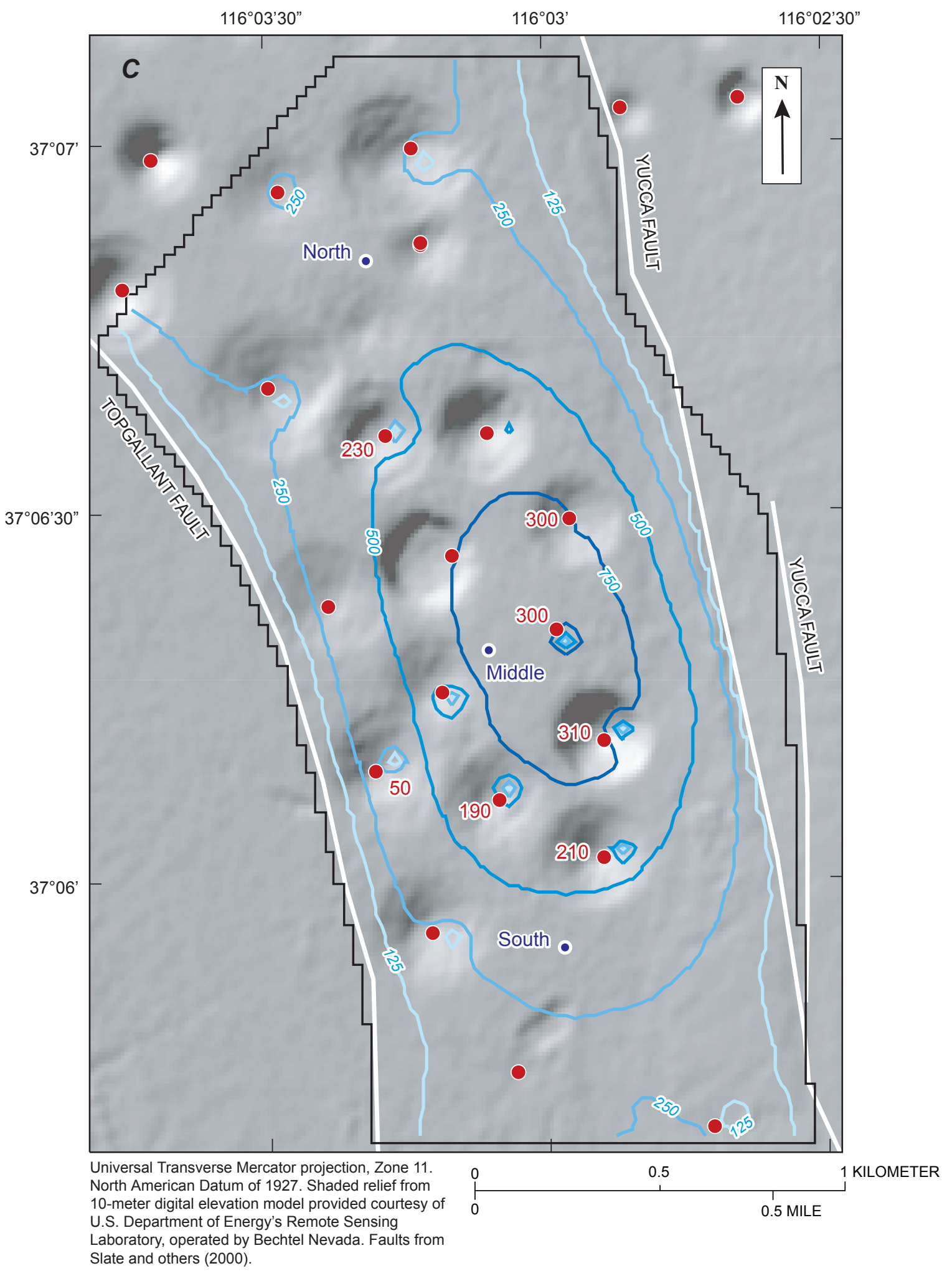

Figure 17. Simulated water-level changes in model layer 5 through (A) March 5, 1967; (B) July 10, 1977; (C) June 28, 1987; and (D) October 23, 1997—Continued. 


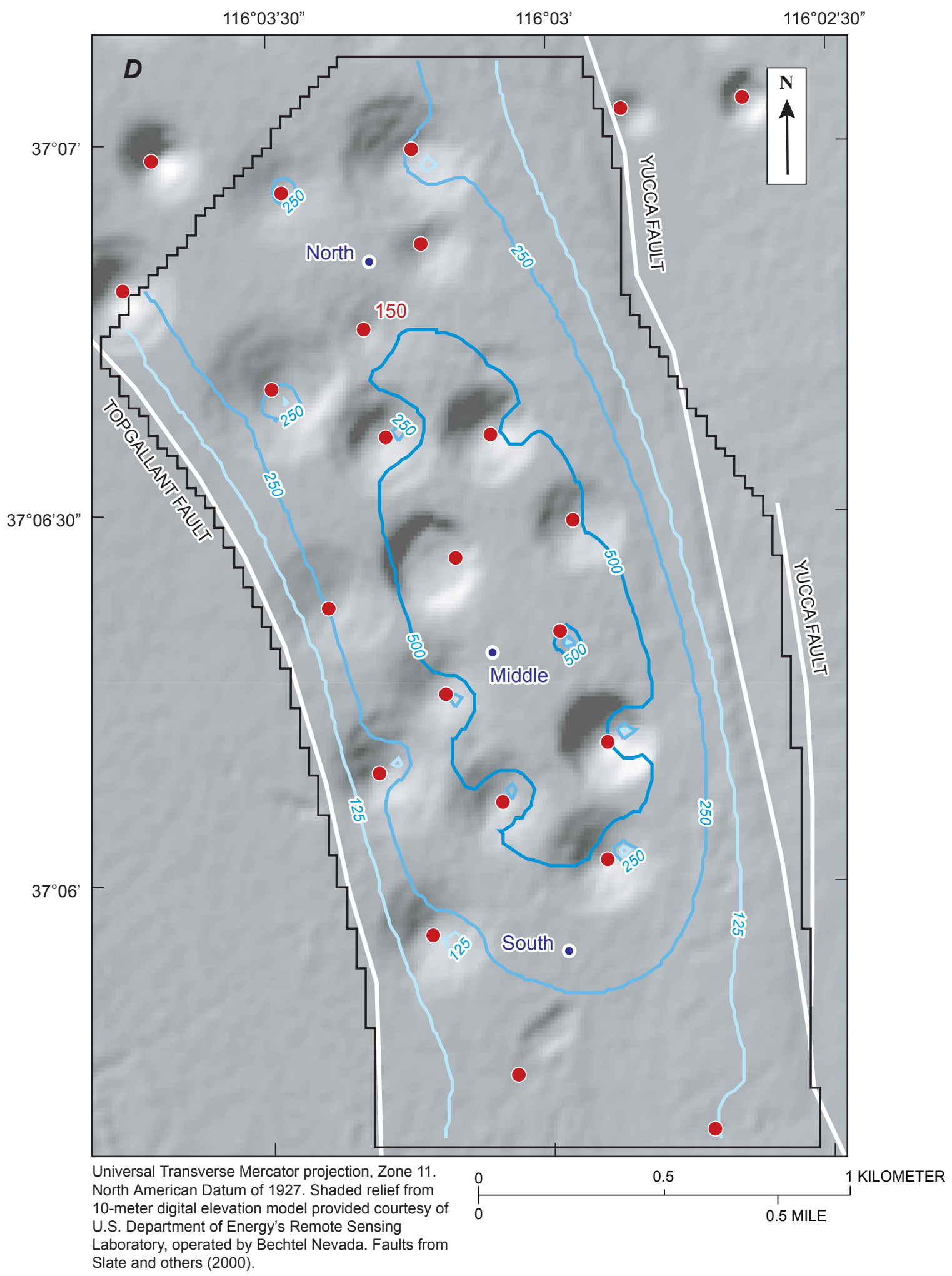

Figure 17. Simulated water-level changes in model layer 5 through (A) March 5, 1967; (B) July 10, 1977; (C) June 28, 1987; and (D) October 23, 1997-Continued. 

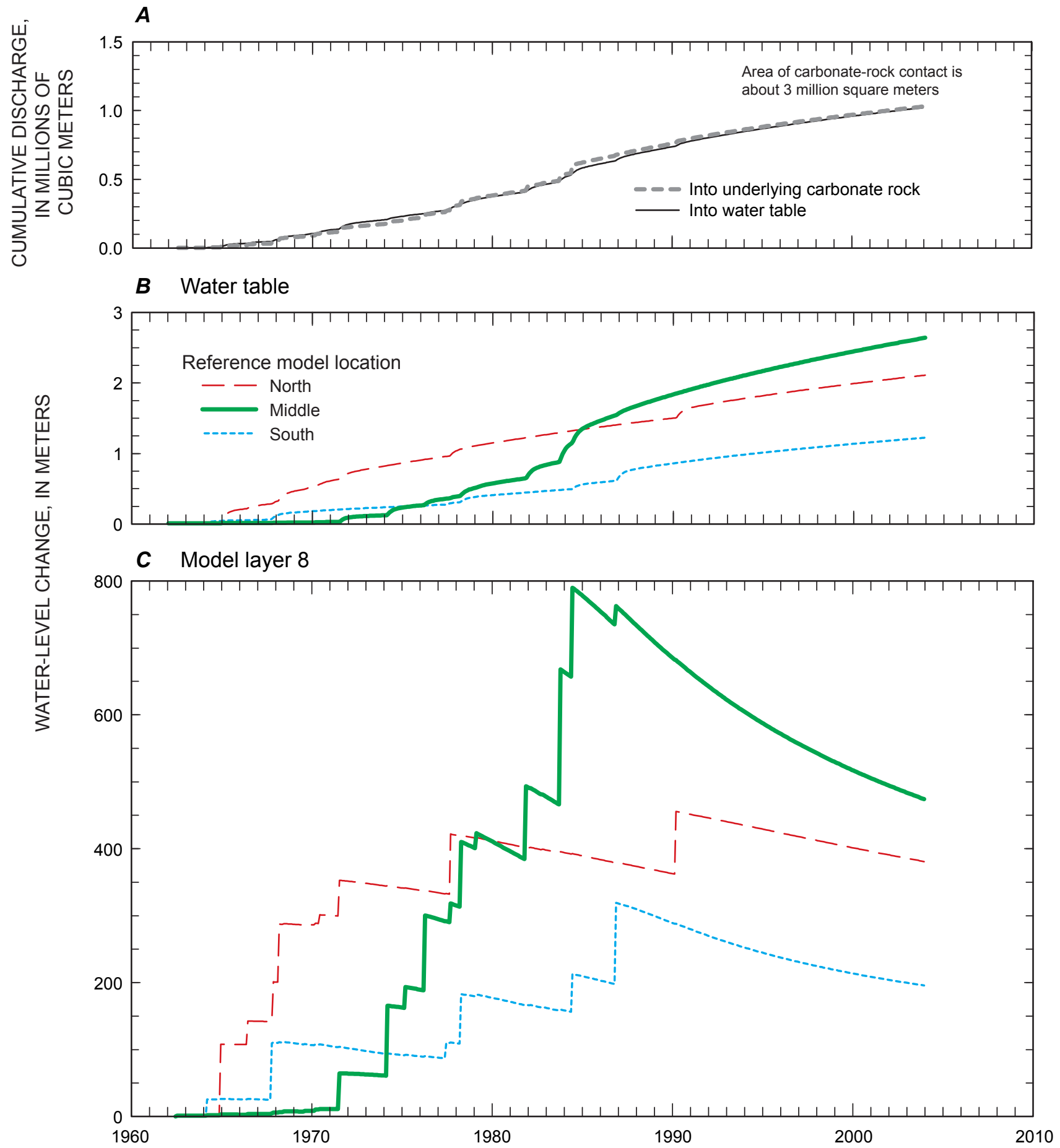

Figure 18. Simulated (A) cumulative discharge into water table and underlying carbonate rock, and water-level changes in (B) water table, and in (C) overpressured tuff at selected locations in model layer 8, 1962 through 2003. Reference model locations are shown in figure 17. 


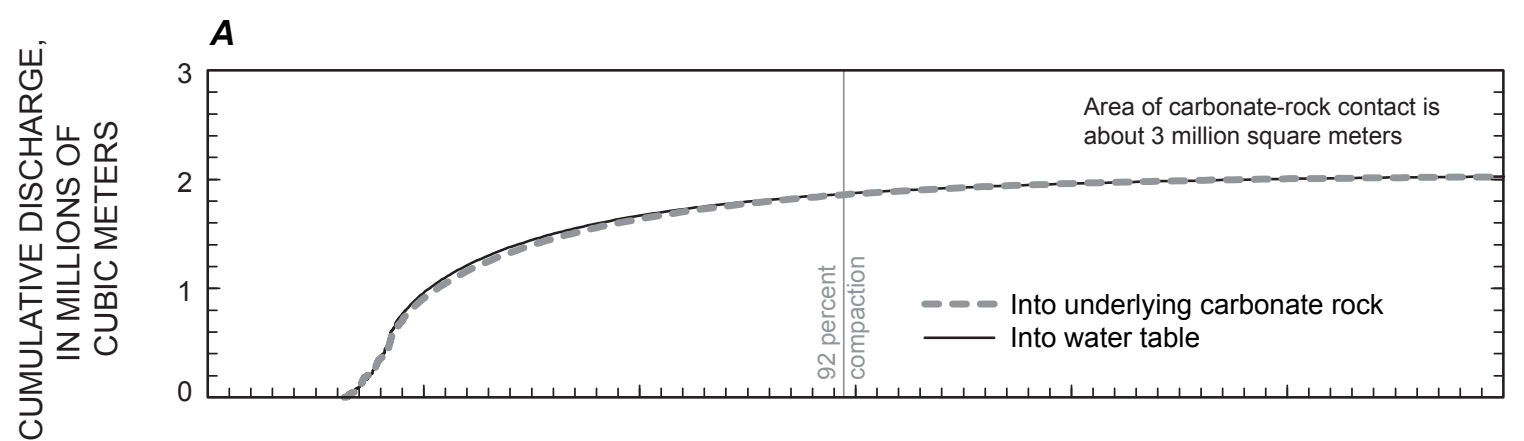

B Water table

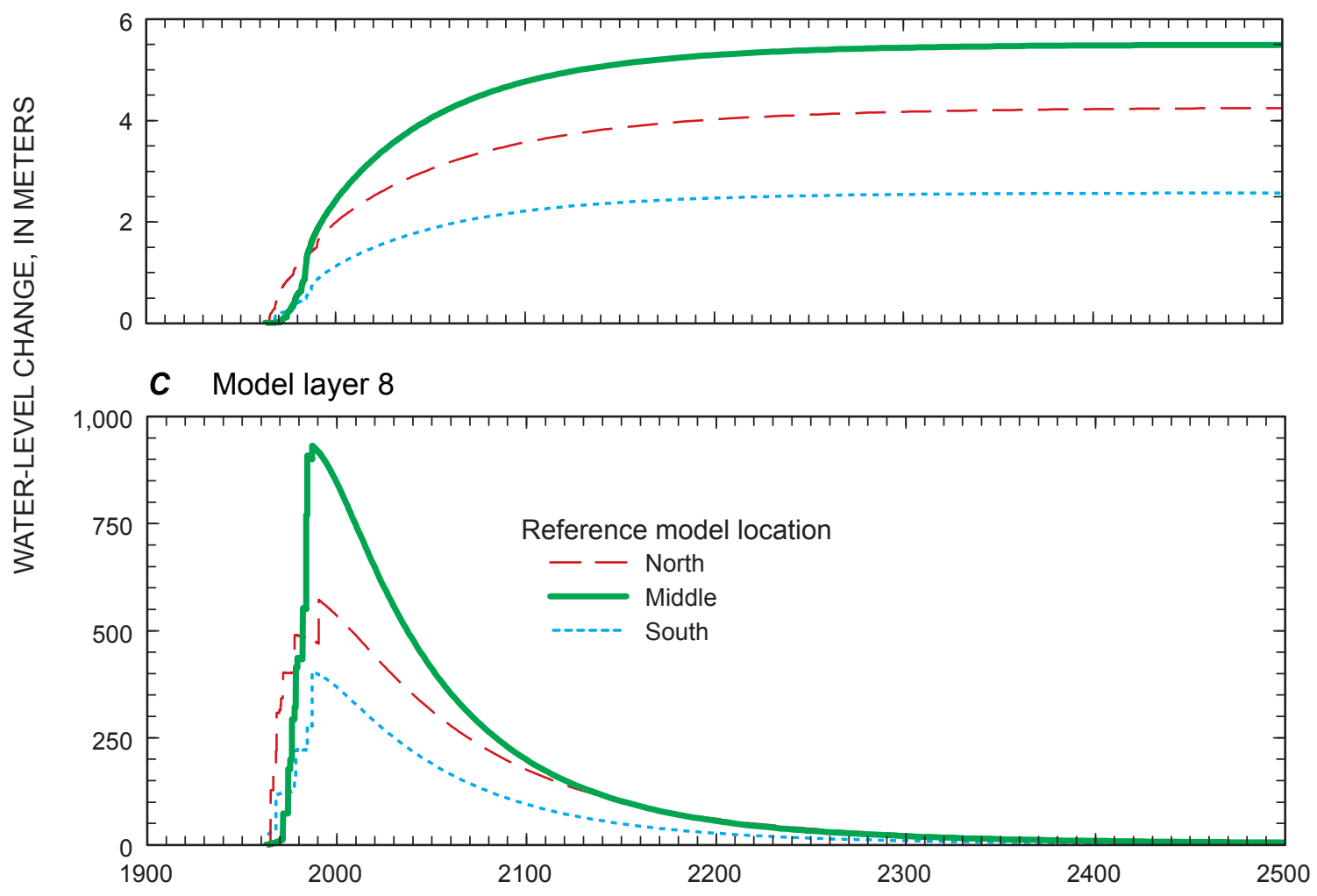

Figure 19. Simulated and predicted (A) cumulative discharge into water table and underlying carbonate rock, and water-level changes in (B) water table, and in (C) overpressured tuff at selected locations in model layer 8, 1962 through 2500. Reference model locations are shown in figure 17. 
Discharge rates were $0.005 \mathrm{~m} / \mathrm{yr}$ in 2005 and declined to $0.0005 \mathrm{~m} / \mathrm{yr}$ by 2300 . Cumulative discharge from bedded tuffs into carbonate rock for the simulation period was about $0.7 \mathrm{~m}$ $\left(\mathrm{m}^{3} / \mathrm{m}^{2}\right)$.

\section{Model and Conceptual Limitations}

Models were developed primarily to investigate whether observed, regional subsidence could be explained adequately by poroelastic deformation of bedded tuffs in response to postdetonation depressurization. These models, as developed, are limited by the assumptions and simplifications inherent in this conceptualization. Model accuracy and the appropriateness of the assumption of poroelastic deformation are limited severely by a lack of available ground-water data, particularly in the bedded tuffs, and by an absence of pre-detonation and co-detonation subsidence distributions throughout the area of study. Although available water levels include some pre-detonation and post-detonation measurements, the calibration of the twoand three-dimensional models is based on a single hydrograph of water levels from a well open to the bedded tuffs. Waterlevel measurements from other locations within the bedded tuffs and adjacent aquifers would further constrain model calibration. Additional data are needed for further evaluation of the poroelastic deformation assumption.

The current subsidence history is limited to the post-detonation period, 1992-98. Extending the history of subsidence beyond 1998 would provide additional observations for model calibration. This study attempted to extend the subsidence history through 2000 but was unsuccessful because of the poor quality of SAR images acquired by an aging satellite. Although it is realized that subsidence data from the study area will not be available prior to 1992, pre-detonation and codetonation subsidence data could be obtained if underground nuclear testing resumes in the future.

A major simplifying assumption limiting this analysis is that all observed subsidence is caused only by elastic deformation within the bedded tuffs. Although the observed subsidence could be explained by other hydrologic and mechanical processes, this assumption seems reasonable because observed subsidence rates are consistent with the compaction expected from the magnitude of measured water-level decline and a storage coefficient representative of elastic conditions.

The lumping of the bedded tuffs into a single bedded-tuff unit also limits the models. The bedded-tuff sequence in the overpressured area of Yucca Flat comprises multiple beddedtuff units but was simulated as an isotropic, homogeneous medium. This simplification allows for the simulation of the system using a bulk hydraulic conductivity. Bulk hydraulic conductivity typically is biased toward the more permeable units where significant differences exist in the hydraulic conductivity of the different units (Hanor, 1993).

Another simplifying assumption of the three-dimensional model is that all detonations were simulated with a uniform radius of alteration, whereas the radius likely varies with the yield of the detonation. An alternative model simulating an alteration radius proportional to the initial water-level rise was used to evaluate the effect of varying radius on model results. In addition to the initial water-level rise, the alternate model estimated a constant of proportionality. Results of this model were inconclusive in that the radii and proportionality parameters were highly correlated. The assumption of a uniform alteration radius was considered reasonable in that both the alternative and calibrated models yielded similar results.

Boundary conditions along the Yucca and Topgallant faults are uncertain. These faults would act as no-flow boundaries, if bedded tuffs in the overpressured area are adjacent to low permeability material, or act as conduits, if faults remain open or are filled with permeable material. Although the hydraulic significance of these faults is uncertain, their influence on model results is mitigated by the low hydraulic conductivity of the bedded tuffs.

\section{SUMMARY AND CONCLUSIONS}

Water-level and subsidence observations were explained well with a poroelastic response model of the zeolitized, bedded tuffs in central Yucca Flat between the Yucca and Topgallant faults. The model simulated water-level response and land subsidence in saturated bedded tuffs compacted by high-energy, compressional, seismic waves from underground detonations. Simulated water levels were elevated more than $700 \mathrm{~m}$ by nuclear testing and declined at rates of less than 10 $\mathrm{m} / \mathrm{yr}$ because of the low hydraulic conductivity of the bedded tuffs. Simulated land subsidence in central Yucca Flat progressed gradually in ovals of more than $10 \mathrm{~km}^{2}$ in response to the slow dissipation of compressed pore fluid and elastic deformation of the bedded tuffs. Subsidence rates as great as $30 \mathrm{~mm} / \mathrm{yr}$ were measured between 1992 and 1997 using InSAR techniques.

Long equilibration periods in wells that were completed in the bedded tuffs allowed water-level recoveries to be analyzed as slug tests. Water levels in these wells equilibrated between 0.3 and 10 years after well completion. Hydraulicconductivity estimates in 9 wells ranged between $3 \times 10^{-7}$ and $9 \times 10^{-4} \mathrm{~m} / \mathrm{d}$ with a geometric mean of $3 \times 10^{-5} \mathrm{~m} / \mathrm{d}$.

Hydraulic properties were estimated equally well with both a simple, cross-sectional model and a more complex, three-dimensional model. Both models were solved using MODFLOW and calibrated to measured water levels and InSAR-derived subsidence rates. The cross-sectional model minimized simulation time which allowed rapid testing of different boundary conditions. The three-dimensional model better depicted the interaction of multiple nuclear detonations within the bedded tuffs in the overpressured area of central Yucca Flat. A hydraulic conductivity of $3 \times 10^{-6} \mathrm{~m} / \mathrm{d}$ was estimated by both models. The similarity of hydraulic-conductivity estimates from "slug tests" and MODFLOW models indicate that the bedded tuffs in the overpressured area are 
isotropic because volumetric constraints and prevalent flow directions differ between the two methods.

Specific storage was estimated uniquely for the bedded tuffs because subsidence measurements were available. Specific storages of $6 \times 10^{-6}$ and $9 \times 10^{-6} \mathrm{~m}^{-1}$ were estimated with the cross-sectional and three-dimensional models, respectively.

A subsurface detonation between 20 and $200 \mathrm{kt}$ can compact rock to distances upwards of $500 \mathrm{~m}$. Detonations were simulated in multiple models as spherical, instantaneous rises in water level with radii of alteration between 400 and 1,000 $\mathrm{m}$. The model with a 700-m radius of alteration and linear water-level rise function best simulated observed water levels and subsidence rates.

The three-dimensional model predicts that only about 2 million $\mathrm{m}^{3}$ or about $0.7 \mathrm{~m}\left(\mathrm{~m}^{3} / \mathrm{m}^{2}\right)$ of additional water will migrate across the contact between the bedded tuffs and carbonate rock as a result of the cumulative effects of past nuclear testing. Simulated discharge and water level decrease exponentially over time. About 50 percent of the simulated ultimate discharge attributed to past nuclear detonations occurs by 2005 and 99 percent occurs by 2400 .

\section{REFERENCES CITED}

App, F.N., and Marusak, N.L., 1997, Tuff Pile 1-A justification for the projection of material properties within a portion of Los Alamos Test Areas 1, 3, 4, and 7- Nevada Test Site: Los Alamos National Laboratory report LA-UR-97-1024, Los Alamos, NM, 45 p.

Bawden, G.W., Sneed, M., Stork, S. V., Galloway, D. L., 2003, Measuring human-induced land subsidence from space: U.S. Geological Survey Fact Sheet 069-03, 4 p.

Belcher, W.R., Sweetkind, D.S., and Elliott, P.E., 2002, Probability distributions of hydraulic conductivity for the hydrogeologic units of the Death Valley Regional Ground-Water Flow System, Nevada and California: U.S. Geological Survey Water-Resources Investigations Report 02-4212, p. 18. Last accessed September 1, 2004, at URL <http://pubs. water.usgs.gov/wri024212>.

Biot, M.A., 1941, General theory of three-dimensional consolidation: Journal of Applied Physics, v. 12, p. 155-164.

Bouwer, Herman, and Rice, R.C., 1976, A slug test for determining hydraulic conductivity of unconfined aquifers with completely or partially penetrating wells: Water Resources Research v. 12, no. 3, p. 423-428.

Burbey, T.J., 2001a, Stress-strain analyses for aquifer-system characterization: Ground Water, v. 39, no. 1, p. 128-136.

Burbey, T.J., 2001b, Storage coefficient revisited-is purely vertical strain a good assumption?: Ground Water, v. 39, no. 3, p. 458-464.
Burkhard, N.R., and Rambo, J.T., 1991, One plausible explanation for water mounding: Proceedings of the Sixth Symposium on Containment of Underground Nuclear Explosions, Lawrence Livermore National Laboratory CONF-91 2, p. 145-158.

Centre National d'Etudes Spatiales (C.N.E.S.), 1997, PRISME/DIAPASON software, version 1.0: Toulouse, France.

D’Agnese, F.A., Faunt, C.C., and Turner, A.K., 1998, An estimated potentiometric surface of the Death Valley region, Nevada and California, developed using geographic information system and automated interpolation techniques: U.S. Geological Survey Water-Resources Investigations Report 97-4052, $15 \mathrm{p}$.

Doty, G.C., and Thordarson, William, 1983, Water table in rocks of Cenozoic and Paleozoic age, 1980, Yucca Flat, Nevada Test Site, Nevada: U.S. Geological Survey WaterResources Investigations Report 83-4067, 1 sheet, scale 1:48,000.

Fenelon, J.M., 2005, Analysis of ground-water levels and associated trends in Yucca Flat, Nevada Test Site, Nye County, Nevada, 1951-2003: U.S. Geological Scientific Investigations Report 2005-5175, 87 p.

Flint, L.E., 1998, Characterization of hydrogeologic units using matrix properties, Yucca Mountain, Nevada: U.S. Geological Survey Water-Resources Investigations Report 97-4243, $64 \mathrm{p}$.

Hale, G.S., Trudeau, D.A., and Savard, C.S., 1995, Water-level data from wells and test holes through 1991 and potentiometric contours as of 1991 for Yucca Flat, Nevada Test Site, Nye County, Nevada: U.S. Geological Survey WaterResources Investigations Report 95-4177, scale 1:48,000.

Hanor, J.S., 1993, Effective hydraulic conductivity of fractured clay beds at a hazardous waste landfill, Louisiana Gulf Coast: Water Resources Research, v. 29, no. 11, p. 3691-3698.

Harbaugh, A.W., and McDonald, M.G., 1996, User's documentation for MODFLOW-96, an update to the U.S. Geological Survey modular finite-difference ground-water flow model: U.S. Geological Survey Open-File Report 96-485, $56 \mathrm{p}$.

Hawkins, W.L., Cavazos, A.P., and Thompson, P.H., 1988, Geologic and hydrologic investigations at the Aleman (U3KZ) site, and other sites in Yucca Flat, the Nevada Test Site, in Olsen, C. W., Donahue, M.L., and Wanden, S. W., eds.: Fourth Symposium on the Containment of Underground Nuclear Explosions: Colorado Springs, Colo., Sandia National Laboratories, Proceedings, CONF-870961, v. 2, p. $387-398$. 
Hawkins, W.L., Trudeau, D.A., and Mihevc, T.M., 1990, Hydrologic testing in exploratory drill hole U-4t, Yucca Flat, the Nevada Test Site, in Olsen, C.W., and Carter, I.A., eds., Fifth Symposium on the Containment of Underground Nuclear Explosions: Santa Barbara, Calif., Lawrence Livermore National Laboratory, Proceedings, CONF-8909163, v. 2, p. 141-159.

Hill, M.C., 1998, Methods and guidelines for effective model calibration: U.S. Geological Survey Water-Resources Investigations Report 98-4005, 90 p.

Hoffmann, Jörn, Zebker, H.A., Galloway, D.L., and Amelung, Falk, 2001, Seasonal subsidence and rebound in Las Vegas Valley, Nevada, observed by synthetic aperture radar interferometry: Water Resources Research, v. 37, no. 6, p. 1551-1566.

Knox, J.B., Rawson, D.E., and Korver, J.A., 1965, Analysis of a groundwater anomaly created by an underground nuclear explosion: Journal of Geophysical Research, v. 70, no. 4, p. $823-835$.

Laczniak, R.J., Cole, J.C., Sawyer, D.A., and Trudeau, D.A., 1996, Summary of hydrogeologic controls on ground-water flow at the Nevada Test Site, Nye County, Nevada: U.S. Geological Survey Water-Resources Investigations Report 96-4109, 59 p.

Laczniak, R.J., Galloway, D.L., and Sneed, Michelle, 2003, InSAR detection of post-seismic and coseismic groundsurface deformation associated with underground weapons testing, Yucca Flat, Nevada Test Site, in Prince, K.R., and Galloway, D.L., eds., U.S. Geological Survey Subsidence Interest Group Conference, Proceedings of the Technical Meeting, Galveston, Texas, November 27-29, 2001: U.S. Geological Survey Open-File Report 03-308, p. 121-128.

Leake, S.A., and Prudic, D.E., 1991, Documentation of a computer program to simulate aquifer-system compaction using the modular finite-difference ground-water flow model: U.S. Geological Survey Techniques of Water-Resources Investigations, book 6, chap. A2, 68 p.

Martin, R.J., Price, R.H., Boyd, P.J., and Noel, J.S., 1994, Bulk and mechanical properties of the Paintbrush Tuff recovered from borehole USW NRG-6: Data Report, Sandia National Laboratories Report SAND93-4020, UC-814, Albuquerque, NM, 92 p.

Martin, R.J., Price, R.H., Boyd, P.J., and Noel, J.S., 1995, Bulk and mechanical properties of the Paintbrush Tuff recovered from borehole USW NRG-7/7A: Data Report, Sandia National Laboratories Report SAND94-1996, UC-814, Albuquerque, NM, 93 p.

Massonnet, Didier, and Feigl, K.L., 1998, Radar interferometry and its application to changes in the Earth's surface: Reviews of Geophysics, v. 36, no. 4, p. 441-500.
Poland, J.F., and Davis, G.H., 1969, Land subsidence due to withdrawal of fluids, in Varnes, D.J., Reviews in engineering geology, v. II: Boulder, Colorado, Geological Society of America, p. 187-268.

Riley, F.S., 1998, Mechanics of aquifer systems-The scientific legacy of Joseph F. Poland, in Borchers, J., ed., Land subsidence-Case Studies and Current Research: Proceedings of the Dr. Joseph F. Poland Symposium on Land Subsidence, Association of Engineering Geologists Special Publication 8, p. 13-27.

Rosen, P.A., Hensley, Scott, Joughin, I.R., Li, F.K., Madsen, S.N., Rodriguez, Ernesto, and Goldstein, R.M., 2000, Synthetic aperture radar interferometry: Proceedings of the IEEE (Institute of Electrical and Electronics Engineers), v. 88 , no. 3, p. 333-382.

Slate, J.L, Berry, M.E., Rowley, P.D., Fridrich, C.J., Morgan, K.S., Workman, J.B., Young, O.D., Dixon, G.L., Williams, V.S., McKee, E.H., Ponce, D.A., Hildenbrand, T.G., Swadley, WC, Lundstrom, S.C., Ekren, E.B., Warren, R.G., Cole, J.C., Fleck, R.J., Lanphere, M.A., Sawyer, D.A., Minor, S.A., Grunwald, D.J., Laczniak, R.J., Menges, C.M., Yount, J.C., and Jayko, A.S., 2000, Digital geologic map of the Nevada Test Site and vicinity, Nye, Lincoln, and Clark counties, Nevada, and Inyo County, California: U.S. Geological Survey Open-File Report 99-554A, 53 p., scale 1:120,000. Last accessed September 2004, at URL < http:// pubs.usgs.gov/of/1999/ofr-99-0554/>.

Smith, L.C., 2002, Emerging applications of Interferometric synthetic aperture radar (InSAR) in geomorphology and hydrology: Annals of the Association of American Geographers, v. 92, no. 3, p. 385-398.

Terzaghi, K., 1925, Erdbaumechanik auf bodenphysikalischer grundlage: Vienna, Deuticke, 399 p.

Terzaghi, K., 1943, Theoretical soil mechanics: New York, John Wiley and Sons, 510 p.

Thordarson, William, 1987, Hydrogeology of the Faultless site, Nye County, Nevada: U.S. Geological Survey WaterResources Investigations Report 86-4342, 40 p.

U.S. Department of Energy, 1997, Shaft and tunnel nuclear detonations at the Nevada Test Site: Development of a primary database for the estimation of potential interactions with the regional groundwater system, Nevada Operations Office, Las Vegas, NV, DOE/NV-464.

U.S. Department of Energy, 2000, United States nuclear tests-July 1945 through September 1992: U.S. Department of Energy, Nevada Operation Office, Las Vegas, NV, DOE/ NV-209 (rev. 15), 162 p. 
U.S. Geological Survey, 2005, National water information system: Ground-water data for Nevada. Last accessed January 1, 2005, at URL <http://waterdata.usgs.gov/nv/nwis/gw/>.

Vincent, P., Larsen, S., Galloway, D.L., Laczniak, R.J., Walter, W.R., Foxall, W. and Zucca, J.J., 2003, New signatures of underground nuclear tests revealed by satellite radar interferometry: Geophysical Research Letters, v. 30, no. 22, p. $1-1-1-5$.

Wang, H.F., 2000, Theory of linear poroelasticity with applications to geomechanics and hydrogeology: Princeton, New Jersey, Princeton University Press, 287 p.

Winograd, I.J., and Thordarson, William, 1975, Hydrogeologic and hydrochemical framework, south-central Great Basin, Nevada-California, with special reference to the Nevada Test Site: U.S. Geological Survey Professional Paper 712-C, $126 \mathrm{p}$.

Wohletz, K., A. Wolfsberg, A. Olson, and C. Gable, 1999, Evaluating the effects of underground nuclear testing below the water table on groundwater and radionuclide migration in the Tuff Pile I Region of Yucca Flat-numerical simulations: EES UGTA FY99 Report, Los Alamos National Laboratory, $31 \mathrm{p}$.

Wolff, R.G., 1982, Physical properties of rocks-Porosity, permeability, distribution coefficients, and dispersivity: U.S. Geological Survey Open-File Report 82-166, 118 p.

Zebker, H.A., Werner, C.L., Rosen, P.A., and Hensley, S., 1994, Accuracy of topographic maps derived from ERS-1 interferometric radar: IEEE (Institute of Electrical and Electronics Engineers) Transactions on Geoscience and Remote Sensing, v. 32, no. 4, p. 823-836. 


\section{APPENDIX}

Single-well slug test analyses of postdrilling water-level recovery to estimate hydraulic conductivity of bedded tuffs in overpressured area of central Yucca Flat.

Complete Appendix follows the back cover. It also is available as Excel file SIR2005-5211.Appendix.xls. 


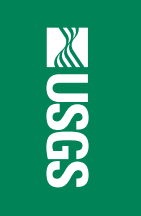

ल

咅

गิ

品.

\%

을

공 ․ㅡㅅ.

을

윈 므

업

产

高

옹

ำ

옥.

흥.

옹

ণิ

Ð

홀

言

巨'

䨠 


\section{Summary Table.}

Single-well slug test analyses of postdrilling water-level recovery to

estimate hydraulic conductivity of bedded tuffs in overpressured area of central Yucca Flat.

[K is hydraulic conductivity, y0-DISPLACEMENT is initial displacement of water column associated with slug. t90\%-recovery is time incurred for hydraulic head to recover to 90 percent of the pre-slug level]

\begin{tabular}{|c|c|c|c|c|}
\hline HOLE IDENTIFIER & $\begin{array}{c}\mathrm{K}, \\
\text { meters/day }\end{array}$ & $\begin{array}{c}\text { y0-DISPLACEMENT, } \\
\text { meters }\end{array}$ & $\begin{array}{l}\text { t90\% recovery, } \\
\text { day }\end{array}$ & Date \\
\hline NTS U-2bs & 9.E-04 & $\overline{55}$ & 75 & $1 / 28 / 1971$ \\
\hline NTS U-2bt & $\overline{9 . E-04}$ & 49 & 15 & 4/7/1971 \\
\hline NTS U-2gh & 2.E-04 & 2 & 320 & 8/1/1988 \\
\hline NTS U-2gk & 1.E-05 & 8 & 6,501 & 10/27/1992 \\
\hline NTS U-4t 1 & 6.E-06 & 9 & 90 & 6/4/1986 \\
\hline NTS U-7cd 1 & 2.E-04 & 77 & 21 & 9/16/1992 \\
\hline NTS UE-4ab-2396 & 6.E-07 & 56 & 2,332 & 8/3/1973 \\
\hline NTS UE-4t 1 & 3.E-07 & 54 & 608 & 11/2/1990 \\
\hline NTS UE-8e-2295 & 9.E-06 & 32 & 199 & $12 / 14 / 1970$ \\
\hline Geomean & 3.E-05 & 23.78358336 & & \\
\hline
\end{tabular}


WELL ID: NTS U-2bs

\begin{tabular}{|cc} 
& \\
& INPUT \\
\hdashline Construction: & \\
Casing dia. (dc) & 99.5 Inch \\
Annulus dia. (dw) & 100 Inch \\
Screen Length (L) & 1800 Feet \\
Depths to: & \\
\hline water level (DTW) & 1620 Feet \\
top of screen (TOS) & 77 Feet \\
Base of Aquifer (DTB) & 2000 Feet \\
Annular Fill: & \\
across screen -- Coarse Sand \\
above screen -- Bentonite
\end{tabular}

Local ID:

U-2bs

$\begin{array}{lr}\text { Date: } & 1 / 28 / 1971 \\ \text { Time: } & 15 \cdot 30\end{array}$

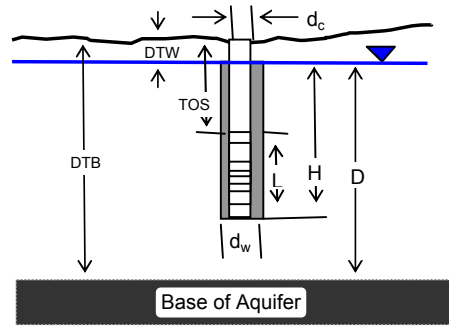

Adjust slope of line to estimate K

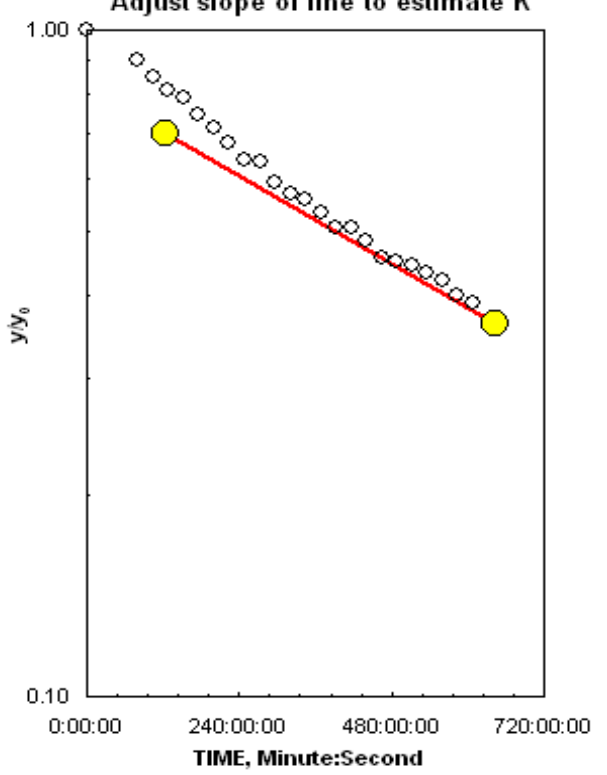

\begin{tabular}{rr}
\hline $\mathrm{K}=$ & 0.003 Feet/Day \\
\hline
\end{tabular}

\begin{tabular}{rr}
\hline $\mathrm{K}=$ & 0.003 Feet/Day \\
\hline
\end{tabular}

TIME, Minute:Secon

REMARKS:

Bouwer and Rice analysis of slug test, WRR 1976

Initial test

\begin{tabular}{|c|c|}
\hline REMARKS: & Bouwer and Rice analysis of slug test, WRR 1976 \\
\hline Initial test & \\
\hline
\end{tabular}

Slope $=1.54321 \mathrm{E}-07 \log 10 / \mathrm{sec}$ t90\% recovery $=\quad 6480000 \mathrm{sec}$
Reduced Data Time, Water Hr:Min:Sec Level 15:30:00.0 $\quad 1900.00$ $18: 00: 00.0 \quad 1905.00$ $21: 00: 00.0 \quad 1911.00$ $0: 00: 00.0 \quad 1904.00$ 0:00:00.0 1882.00 $0: 00: 00.0 \quad 1873.00$ 0:00:00.0 1866.50

$0: 00: 00.0 \quad 1862.00$

$0: 00: 00.0 \quad 1854.00$ $0: 00: 00.0 \quad 1848.00$ $0: 00: 00.0 \quad 1842.00$ $0: 00: 00.0 \quad 1835.00$ $0: 00: 00.0 \quad 1834.00$ $0: 00: 00.0 \quad 1826.00$ $0: 00: 00.0 \quad 1822.00$ $0: 00: 00.0 \quad 1820.00$ 0:00:00.0 $\quad 1816.00$ 0:00:00.0 1811.00 0:00:00.0 1811.00 0:00:00.0 1807.00 0:00:00.0 1802.00 $0: 00: 00.0 \quad 1801.00$ $0: 00: 00.0 \quad 1800.00$ 0:00:00.0 1798.00 0:00:00.0 1796.00 0:00:00.0 1792.00 0:00:00.0 $\quad 1790.00$ 0:00:00.0 $\quad 0.00$ $\begin{array}{ll}0: 00: 00.0 & 0.00\end{array}$ $0: 00: 00.0 \quad 0.00$ $0: 00: 00.0 \quad 0.00$ $\begin{array}{ll}0: 00: 00.0 & 0.00 \\ 0: 00 \cdot 00.0 & 0.00\end{array}$ $\begin{array}{ll}0: 00: 00.0 & 0.00 \\ 0: 00: 00.0 & 0.00\end{array}$ $\begin{array}{ll}0: 00: 00.0 & 0.00\end{array}$ $0: 00: 00.0 \quad 0.00$
$0: 00: 00$ $0: 00: 00.0 \quad 0.00$ 0:00:00.0 $\quad 0.00$ 0:00:00.0 $\quad 0.00$ $0: 00: 00.0 \quad 0.00$ $0: 00: 00.0 \quad 0.00$ $\begin{array}{ll}0: 00: 00.0 & 0.00 \\ 0: 00: 00.0 & 0.00\end{array}$ 0:00:00.0 $\quad 0.00$ $0: 00: 00.0 \quad 0.00$ 0:00:00.0 $\quad 0.00$ 0:00:00.0 $\quad 0.00$ $\begin{array}{ll}0: 00: 00.0 & 0.00 \\ 0: 00: 00.0 & 0.00\end{array}$ $\begin{array}{ll}0: 00: 00.0 & 0.00 \\ 0: 00: 00.0 & 0.00\end{array}$
$0: 00: 00.0$ 0:00:00.0 0:00:00.0 0:00:00.0 $0: 00: 00.0$ $0.00 \cdot 00.0$ 0:00:00.0 $0.00 \cdot 00.0$ $0: 00.00 .0$ 0:00:00.0 $0: 00: 00.0$ 0:00:00.0 0:00:00.0 0:00:00.0 0:00:00.0 $0: 00: 00.0$ 0:00:00.0 0:00:00.0 0:00:00.0 $0: 00: 00.0$ 0.00 .00 .0 0:00:00.0 0:00:00.0 0:00:00.0 0:00:00.0 0:00:00.0 $0: 00: 00.0$ $0: 00: 00.0$ $0.00: 00.0$ 0:00:00.0 0:00:00.0 0:00:00.0 0:00:00.0 $0: 00: 00.0$ $0: 00: 00.0$ 0:00:00.0 0:00:00.0 0:00:00.0 $0: 00: 00.0$ 0:00:00.0 0:00:00.0 0:00:00.0 0:00:00.0 0:00:00.0 0:00:00.0 $0: 00: 00.0$ $0: 00: 00.0$ $0.00: 00.0$ 0:00:00.0 0:00:00.0 0:00:00.0
0.00

0.00

0.00

0.00

0.00

0.00

0.00

0.00

0.00

0.00

0.00

0.00

0.00

0.00

0.00

0.00

0.00

0.00

0.00

0.00

0.00

0.00

0.00

0.00

0.00

0.00

0.00

0.00

0.00

0.00

0.00

0.00

0.00

0.00

0.00

0.00

0.00
0.00

0.00

0.00

0.00

0.00

0.00 0.00
0.00 
WELL ID: NTS U-2bt

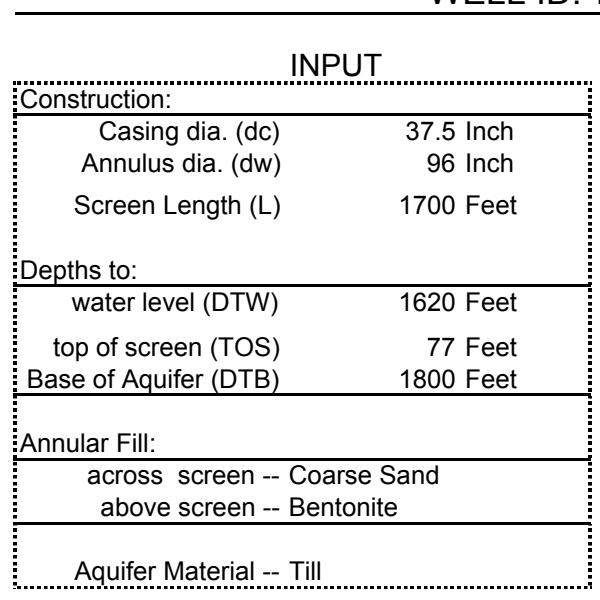

Local ID:

$\mathrm{U}-2 \mathrm{bt}$

Date:

$\mathrm{U}-2 \mathrm{bt}$
$7 / 1971$
$0: 00$

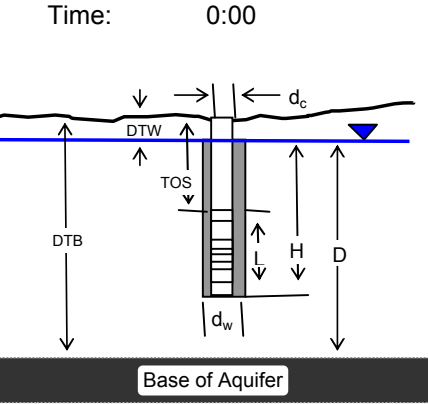

Adjust slope of line to estimate $\mathrm{K}$
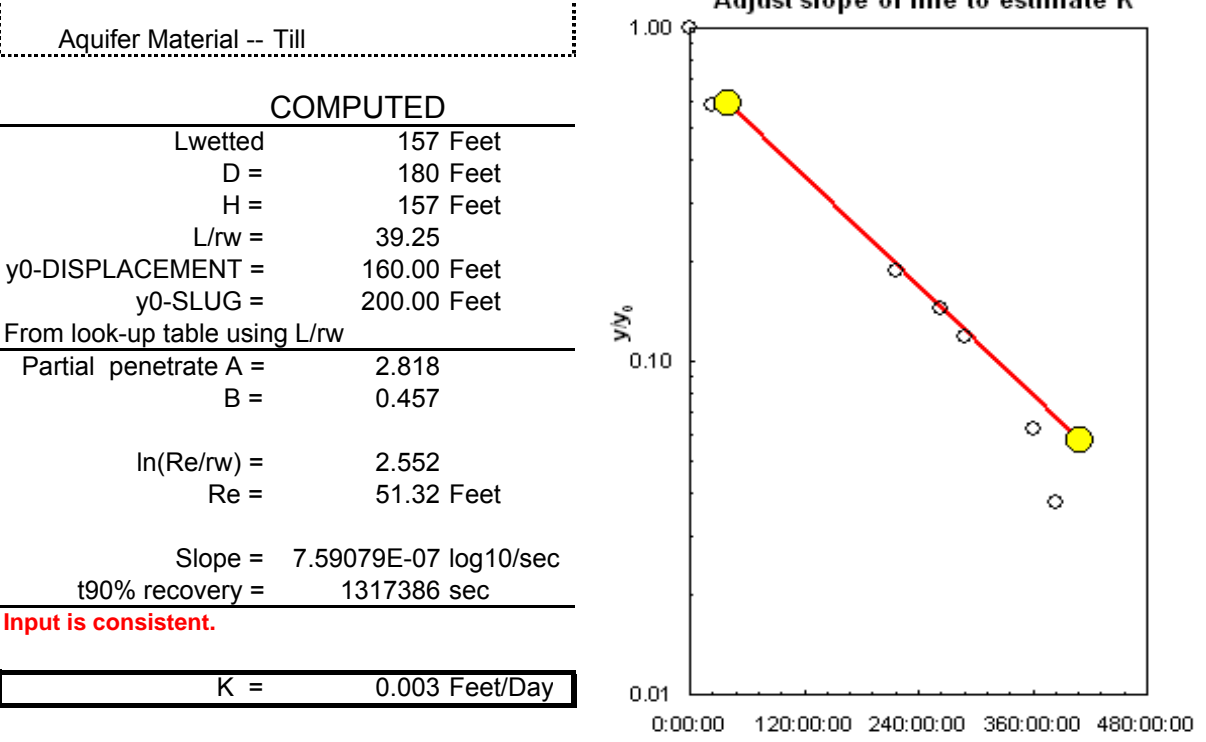

TIME, Minute:Second

REMARKS:

Bouwer and Rice analysis of slug test, WRR 1976

Initial test

Initial test

Slope $=759079 \mathrm{E}-07 \log 10 / \mathrm{sed}$ t90\% recovery $=\quad 1317386 \mathrm{sec}$

$\mathrm{K}=\quad 0.003$ Feet/Day
Reduced Data Time, Water

r:Min:Sec Level

0:00:00.0 1780.00

$0: 00: 00.0 \quad 1714.00$

$0: 00: 00.0 \quad 1650.00$

0:00:00.0 1643.00

$0: 00: 00.0 \quad 1639.00$

$0: 00: 00.0 \quad 1630.00$

$0: 00: 00.0 \quad 1626.00$

$0: 00: 00.0 \quad 0.00$

$0: 00: 00.0 \quad 0.00$

$0: 00: 00.0 \quad 0.00$

0.00

$0: 00: 00.0 \quad 0.00$

$0: 00: 00.0 \quad 0.00$

$0: 00: 00.0 \quad 0.00$

$0.00: 00.0-0.00$

$\begin{array}{ll}0: 00: 00.0 & 0.00 \\ 0: 00 \cdot 00.0 & 0.00 \\ 0.00: 00.0 & 0.00\end{array}$

$0: 00: 00.0 \quad 0.00$

$0: 00: 00.0 \quad 0.00$

$0: 00: 00.0 \quad 0.00$

$0: 00: 00.0 \quad 0.00$

$0: 00: 00.0 \quad 0.00$

$0: 00: 00.0 \quad 0.00$

$\begin{array}{ll}0: 00: 00.0 & 0.00 \\ 0: 00: 00.0 & 0.00 \\ 0: 00: 00.0 & 0.00\end{array}$

$0: 00: 00.0 \quad 0.00$

$0: 00: 00.0 \quad 0.00$

0:00:00.0 $\quad 0.00$

$0: 00: 00.0 \quad 0.00$

$0: 00: 00.0 \quad 0.00$

$0: 00: 00.0 \quad 0.00$

$0: 00: 00.0 \quad 0.00$

$0: 00: 00.0 \quad 0.00$

0:00:00.0 $\quad 0.00$

$0: 00: 00.0 \quad 0.00$

$0: 00: 00.0 \quad 0.00$

$0.00: 00.0 \quad 00$

$0: 00: 00.0 \quad 0.00$

$0: 00: 00.0 \quad 0.00$

$0: 00: 00.0 \quad 0.00$

$0: 00: 00.0 \quad 0.00$

0:00:00.0 $\quad 0.00$

$00: 00.0 \quad 0.00$

$0: 00: 00.0 \quad 0.00$

$0: 00: 00.0 \quad 0.00$

$0.00 \cdot 00.000$

$0: 00: 00.0 \quad 0.00$

$\begin{array}{ll}0.00 .00 .0 & 0.00 \\ 0: 00: 00.0 & 0.00\end{array}$

0:00:00.0

0.00

$\begin{array}{ll}\text { 0:00:00.0 } & 0.00 \\ 0: 00: 00.0 & 0.00 \\ 0: 00: 00.0 & 0.00 \\ 0: 00: 00.0 & 0.00 \\ 0: 00: 00.0 & 0.00 \\ 0: 00: 00.0 & 0.00 \\ 0: 00: 00.0 & 0.00 \\ 0: 00: 00.0 & 0.00 \\ 0: 00: 00.0 & 0.00 \\ 0: 00: 00.0 & 0.00 \\ 0: 00: 00.0 & 0.00 \\ 0: 00: 00.0 & 0.00 \\ 0: 00: 00.0 & 0.00 \\ 0: 00: 00.0 & 0.00 \\ 0: 00: 00.0 & 0.00 \\ 0: 00: 00.0 & 0.00 \\ 0: 00: 00.0 & 0.00 \\ 0: 00: 00.0 & 0.00 \\ 0: 00: 00.0 & 0.00 \\ 0: 00: 00.0 & 0.00 \\ 0: 00: 00.0 & 0.00 \\ 0: 00: 00.0 & 0.00 \\ 0: 00: 00.0 & 0.00 \\ 0: 00: 00.0 & 0.00 \\ 0: 00: 00.0 & 0.00 \\ 0: 00: 00.0 & 0.00 \\ 0: 00: 00.0 & 0.00 \\ 0: 00: 00.0 & 0.00 \\ 0: 00: 00.0 & 0.00 \\ 0: 00: 00.0 & 0.00 \\ 0: 00: 00.0 & 0.00 \\ 0: 00: 00.0 & 0.00 \\ 0: 00: 00.0 & 0.00 \\ 0: 00: 00.0 & 0.00 \\ 0: 00: 00.0 & 0.00 \\ 0: 00: 00.0 & 0.00 \\ 0: 00: 00.0 & 0.00 \\ 0: 00: 00.0 & 0.00 \\ 0: 00: 00.0 & 0.00 \\ 0: 00: 00.0 & 0.00 \\ 0: 00: 00.0 & 0.00 \\ 0: 00: 00.0 & 0.00 \\ 0: 00: 00.0 & 0.00 \\ 0: 00: 00.0 & 0.00 \\ 0: 00: 00.0 & 0.00 \\ 0: 00: 00.0 & 0.00 \\ 0: 00: 00.0 & 0.00 \\ 0: 00: 00.0 & 0.00 \\ 0: 00: 00.0 & 0.00 \\ 0: 00: 00.0 & 0.00 \\ 0: 00: 00.0 & \end{array}$

.00

0.00

.00

0.00

00

0.00

0.00

0.00

0.00

0.00

0.00

0.00

0.00

0.00

0.00

0.00

0.00

0.00

0.00

0.00

0.00

00

0.00

0.00

0.00

0.00

0.00

.00

0.00

0.00

0.00

0.00

0:00:00.0 
WELL ID: NTS U-2gh

\begin{tabular}{|c|c|}
\hline \multicolumn{2}{|c|}{ INPUT } \\
\hline \multicolumn{2}{|l|}{ Construction: } \\
\hline Casing dia. (dc) & 98 Inch \\
\hline Annulus dia. (dw) & 120 Inch \\
\hline Screen Length (L) & 1700 Feet \\
\hline \multicolumn{2}{|l|}{ Depths to: } \\
\hline water level (DTW) & 1620 Feet \\
\hline top of screen (TOS) & 77 Feet \\
\hline Base of Aquifer (DTB) & 2000 Feet \\
\hline \multicolumn{2}{|l|}{ Annular Fill: } \\
\hline \multicolumn{2}{|c|}{$\begin{array}{l}\text { across screen -- Coarse Sand } \\
\text { above screen -- Bentonite }\end{array}$} \\
\hline
\end{tabular}

$\begin{array}{rr}\text { Local ID: } & \mathrm{U}-2 \mathrm{~g} \\ \text { Date: } & 8 / 1 / 1988\end{array}$

Date: $\quad 8 / 1 / 1988$

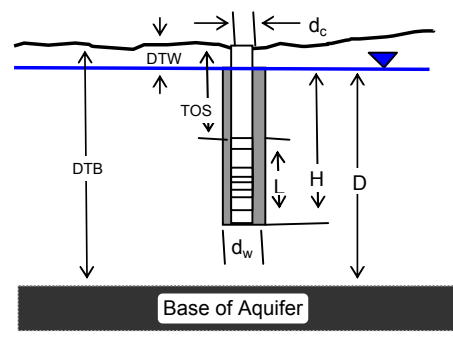

Adjust slope of line to estimate $K$

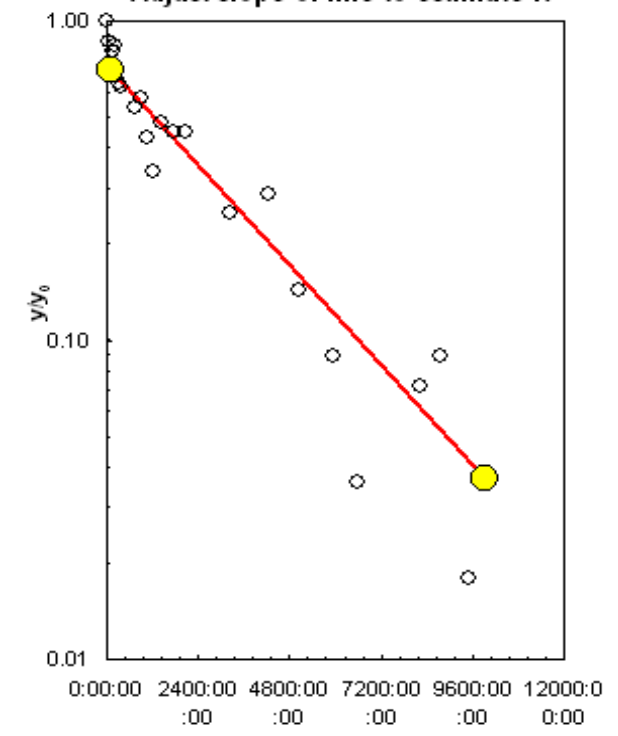

$0.0008 \mathrm{Feet} / \mathrm{Da}$

TIME, Minute:Secon

$K=0.0008$ is less than likely minimum of 0.003 for Till

REMARKS:

Bouwer and Rice analysis of slug test, WRR 1976

Initial test

Initial test

Reduced Data Time,

Water

Hr:Min:Sec Level

$11: 30: 00.0 \quad 1577.60$

$13: 30: 00.0 \quad 1576.80$

$12: 45: 00.0 \quad 1576.50$

$13: 45: 00.0 \quad 1576.70$

$13: 40: 00.0 \quad 1575.60$

$12 \cdot 00: 00.0 \quad 1575.50$

9:30:00.0 $\quad 1575.00$

$7: 30: 00.0 \quad 1575.20$

9:30:00.0 $\quad 1574.40$

13:37:00.0 $\quad 1573.90$

9:41:00.0 $\quad 1574.70$

12:09:00.0 1574.50

14:30:00.0 1574.50

14:10:00.0 1573.40

9:25:00.0 $\quad 1573.60$

$12: 55: 00.0 \quad 1572.80$

$12: 15: 00.0 \quad 1572.50$

10:50:00.0 $\quad 1572.20$

14:00:00.0 $\quad 1572.40$

10:50:00.0 $\quad 1572.50$

$11: 20: 00.0 \quad 1572.10$

$0: 00: 00.0 \quad 0.00$

0:00:00.0 $\quad 0.00$

0:00:00.0 $\quad 0.00$

0:00:00.0 $\quad 0.00$

0:00:00.0 $\quad 0.00$

0:00:00.0 $\quad 0.00$

0:00:00.0 $\quad 0.00$

$0.00: 00.0 \quad 0.00$

$\begin{array}{ll}0: 00: 00.0 & 0.00 \\ 0: 00: 00.0 & 0.00\end{array}$

$0: 00: 00.0 \quad 0.00$

$0: 00: 00.0 \quad 0.00$

$0: 00: 00.0 \quad 0.00$

0:00:00.0 $\quad 0.00$

$\begin{array}{ll}0: 00: 00.0 & 0.00\end{array}$

$0: 00: 00.0 \quad 0.00$

0:00:00.0 $\quad 0.00$

$0: 00: 00.0 \quad 0.00$

0:00:00.0 $\quad 0.00$

$0: 00: 00.0 \quad 0.00$

$0: 00: 00.0 \quad 0.00$

$0.00: 00.0 \quad 0.00$

$0: 00: 00.0 \quad 0.00$

$\begin{array}{ll}0: 00: 00.0 & 0.00 \\ 0: 00: 00.0 & 0.00\end{array}$

$0.00 \cdot 00.0-0.00$

$0.00 .00 .0-0.00$

$0: 00: 00.0$

0.00
0.00

0:00:00.0

0.00
0:00:00.0

$0.00 \cdot 00.0$

$0.00: 00.0$

$0: 00: 00.0 \quad 0.00$

$0: 00: 00.0 \quad 0.00$

0:00:00.0 $\quad 0.00$

$0: 00: 00.0 \quad 0.00$

$0: 00: 00.0 \quad 0.00$

$0: 00: 00.0 \quad 0.00$

0:00:00.0 $\quad 0.00$

$0: 00: 00.0 \quad 0.00$

$0: 00: 00.0 \quad 0.00$

$0: 00: 00.0 \quad 0.00$

$0: 00: 00.0 \quad 0.00$

$0: 00: 00.0 \quad 0.00$

$0: 00: 00.0 \quad 0.00$

$0: 00: 00.0 \quad 0.00$

$0: 00: 00.0 \quad 0.00$

0:00:00.0 $\quad 0.00$

$0: 00: 00.0 \quad 0.00$

$0: 00: 00.0 \quad 0.00$

0:00:00.0 $\quad 0.00$

$0: 00: 00.0 \quad 0.00$

$\begin{array}{ll}0: 00: 00.0 & 0.00 \\ 0: 00: 00.0 & 0.00\end{array}$

$0: 00: 00.0 \quad 0.00$

0:00:00.0 $\quad 0.00$

$0: 00: 00.0 \quad 0.00$

$0: 00: 00.0 \quad 0.00$

$0: 00: 00.0 \quad 0.00$

0:00:00.0 $\quad 0.00$

$0: 00: 00.0 \quad 0.00$

$0: 00: 00.0 \quad 0.00$

$0: 00: 00.0 \quad 0.00$

0:00:00.0 $\quad 0.00$

$0: 00: 00.0 \quad 0.00$

$0: 00: 00.0 \quad 0.00$

$0: 00: 00.0 \quad 0.00$

$0: 00: 00.0 \quad 0.00$

0:00:00.0 $\quad 0.00$

0:00:00.0 $\quad 0.00$

$0: 00: 00.0 \quad 0.00$

$\begin{array}{ll}0: 00: 00.0 & 0.00 \\ 0: 00: 00.0 & 0.00\end{array}$

$0: 00: 00.0 \quad 0.00$

$0: 00: 00.0 \quad 0.00$

0:00:00.0

$0: 00: 00.0 \quad 0.00$

0:00:00.0 $\quad 0.00$ 
WELL ID: NTS U-2gk

\begin{tabular}{|c|c|}
\hline \multicolumn{2}{|c|}{ INPUT } \\
\hline \multicolumn{2}{|l|}{ Construction: } \\
\hline Casing dia. (dc) & 98 Inch \\
\hline Annulus dia. (dw) & 100 Inch \\
\hline Screen Length (L) & 1700 Feet \\
\hline \multicolumn{2}{|l|}{ Depths to: } \\
\hline water level (DTW) & 1620 Feet \\
\hline top of screen (TOS) & 120 Feet \\
\hline Base of Aquifer (DTB) & 2000 Feet \\
\hline \multicolumn{2}{|l|}{ Annular Fill: } \\
\hline \multicolumn{2}{|c|}{$\begin{array}{l}\text { across screen -- Coarse Sand } \\
\text { above screen -- Bentonite }\end{array}$} \\
\hline
\end{tabular}

$\begin{array}{rr}\text { Local ID: } & \text { U-2gk } \\ \text { Date: } & 10 / 27 / 1992\end{array}$

Date: 10/27/1992

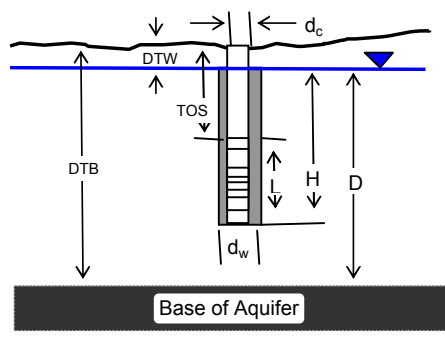

Adjust slope of line to estimate $K$

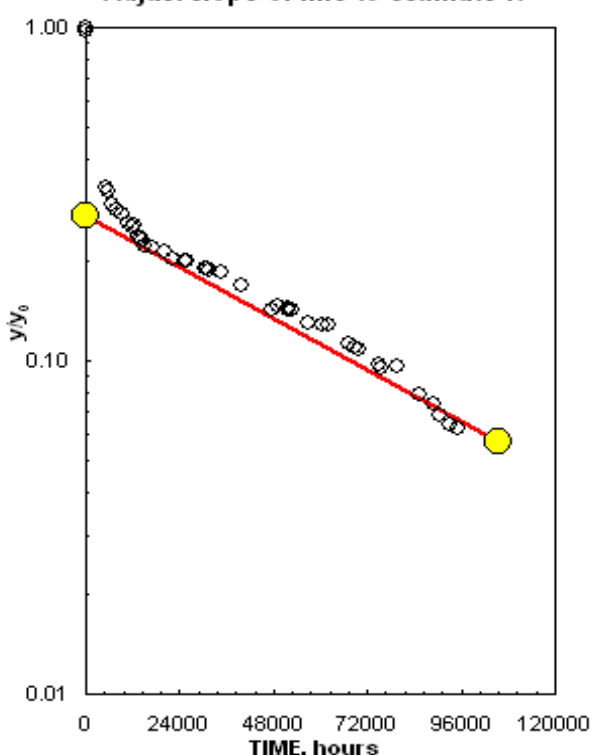

$K=0.00004$ is less than likely minimum of 0.003 for Till

REMARKS:

Bouwer and Rice analysis of slug test, WRR 1976
Reduced Data

Time,

Water

Level

$14: 25: 00.0 \quad 1803.40$

$10: 49: 00.0 \quad 1802.60$

9:37:00.0 $\quad 1785.10$

$10: 40: 00.0 \quad 1784.80$

10:06:00.0 1784.02

$10: 20: 00.0 \quad 1783.72$

$10: 42: 00.0 \quad 1783.52$

10:39:00.0 1783.07

$12: 35: 00.0 \quad 1782.87$

9.21:00.0 1782.97

$10 \cdot 52 \cdot 00.0 \quad 1782.44$

16:03:00.0 1782.35

14:04:00.0 1782.31

13:27:00.0 1782.09

13:07:00.0 $\quad 1781.99$

11:58:00.0 $\quad 1781.79$

9.39:00.0 $\quad 1781.54$

17:24:00.0 1781.45

9:45:00.0 1781.46

13:11:00.0 1781.21

$12: 36: 00.0 \quad 1781.17$

8:26:00.0 1781.13

$8: 40: 00.0 \quad 1781.02$

8:38:00.0 1780.63

11:14:00.0 1779.90

8:48:00.0 1779.97

9:27:00.0 1779.95

13:01:00.0 1779.91

9.39:00.0 1779.89

13.26:00.0 1779.55

12:36:00.0 1779.52

10:32:00.0 1779.50

10:17:00.0 1779.08

13:07:00.0 $\quad 1779.02$

$10: 40: 00.0 \quad 1778.97$

$14: 21: 00.0 \quad 1778.68$

13:56:00.0 $\quad 1778.61$

11:32:00.0 1778.63

9:08:00.0 $\quad 1778.16$

11:36:00.0 1778.04

15:03:00.0 $\quad 1777.88$

8:53:00.0 1777.77

9:47:00.0 1777.72

$0: 00: 00.0 \quad 0.00$

$0: 00: 00.0 \quad 0.00$

0:00:00.0 $\quad 0.00$

0:00:00.0 $\quad 0.00$

$0: 00: 00.0 \quad 0.00$

0.00
0.00

$\begin{array}{ll}0: 00: 00.0 & 0.00 \\ 0: 00: 00.0 & 0.00 \\ 0: 00: 00.0 & 0.00 \\ 0: 00: 00.0 & 0.00 \\ 0: 00: 00.0 & 0.00 \\ 0: 00: 00.0 & 0.00 \\ 0: 00: 00.0 & 0.00 \\ 0: 00: 00.0 & 0.00 \\ 0: 00: 00.0 & 0.00 \\ 0: 00: 00.0 & 0.00 \\ 0: 00: 00.0 & 0.00 \\ 0: 00: 00.0 & 0.00 \\ 0: 00: 00.0 & 0.00 \\ 0: 00: 00.0 & 0.00 \\ 0: 00: 00.0 & 0.00 \\ 0: 00: 00.0 & 0.00 \\ 0: 00: 00.0 & 0.00 \\ 0: 00: 00.0 & 0.00 \\ 0: 00: 00.0 & 0.00 \\ 0: 00: 00.0 & 0.00 \\ 0: 00: 00.0 & 0.00 \\ 0: 00: 00.0 & 0.00 \\ 0: 00: 00.0 & 0.00 \\ 0: 00: 00.0 & 0.00 \\ 0: 00: 00.0 & 0.00 \\ 0: 00: 00.0 & 0.00 \\ 0: 00: 00.0 & 0.00 \\ 0: 00: 00.0 & 0.00 \\ 0: 00: 00.0 & 0.00 \\ 0: 00: 00.0 & 0.00 \\ 0: 00: 00.0 & 0.00 \\ 0: 00: 00.0 & 0.00 \\ 0: 00: 00.0 & 0.00 \\ 0: 00: 00.0 & 0.00 \\ 0: 00: 00.0 & 0.00 \\ 0: 00: 00.0 & 0.00 \\ 0: 00: 00.0 & 0.00 \\ 0: 00: 00.0 & 0.00 \\ 0: 00: 00.0 & 0.00 \\ 0: 00: 00.0 & 0.00 \\ 0: 00: 00.0 & 0.00 \\ 0: 00: 00.0 & 0.00 \\ 0: 00: 00.0 & 0.00 \\ 0: 00: 00.0 & 0.00 \\ 0: 00: 00.0 & 0.00 \\ 0: 00: 00.0 & 0.00 \\ 0: 00: 00.0 & 0.00 \\ 0: 00: 00.0 & 0.00 \\ 0: 00: 00.0 & 0.00 \\ 0: 00: 00.0 & 0.00 \\ 0: 00: 00.0 & \end{array}$

.00

.00

0.00

0.00

0.00

00

0.00

0.00

0.00

.00

0.00

0.00

0.00

0.00

.00

0.00

0.00

0.00

0.00

0.00

.00

0.00

0.00

0.00

0.00

0.00

.00

0.00

0.00

0.00

0.00

00

0.00

.00 
WELL ID: NTS U-4t 1

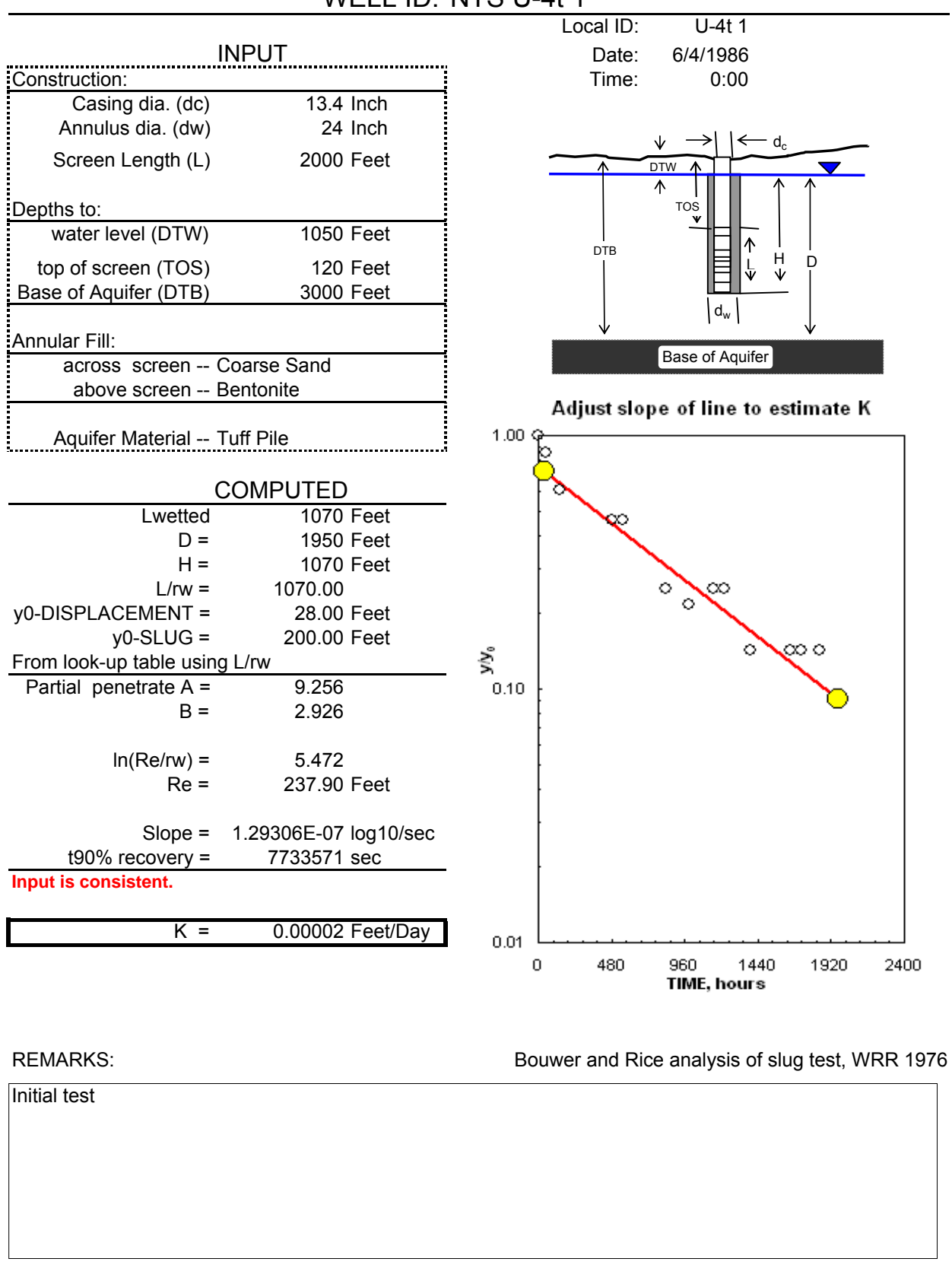

Reduced Data Time, Water Hr:Min:Sec Level 0:00:00.0 1058.00 $\begin{array}{ll}0: 00: 00.0 & 1054.00 \\ 0: 00: 00.0 & 1047.00\end{array}$ 0:00:00.0 1043.00 $0: 00: 00.0 \quad 1043.00$ 0:00:00.0 $\quad 1037.00$ $0: 00: 00.0 \quad 1036.00$ 0:00:00.0 1037.00 0:00:00.0 1037.00 $0: 00: 00.0 \quad 1034.00$ $0: 00: 00.0 \quad 1034.00$ 0:00:00.0 1034.00 0:00:00.0 1034.00 $\begin{array}{ll}0: 00: 00.0 & 0.00 \\ 0 & 00000\end{array}$ 0:00:00.0 $\quad 0.00$ $0: 00: 00.0 \quad 0.00$ $0: 00: 00.0 \quad 0.00$ 0:00:00.0 $\quad 0.00$ $0: 00: 00.0 \quad 0.00$ 0:00:00.0 $\quad 0.00$ $0: 00: 00.0 \quad 0.00$ $0: 00: 00.0 \quad 0.00$ 0:00:00.0 $\quad 0.00$ $\begin{array}{ll}0: 00: 00.0 & 0.00 \\ 0: 00: 00.0 & 0.00\end{array}$ 0:00:00.0 $\quad 0.00$ 0:00:00.0 $\quad 0.00$ 0:00:00.0 $\quad 0.00$ $0: 00: 00.0 \quad 0.00$ 0:00:00.0 $\quad 0.00$ 0:00:00.0 $\quad 0.00$ $\begin{array}{ll}0: 00: 00.0 & 0.00 \\ 0: 00 \cdot 00.0 & 0.00\end{array}$ $\begin{array}{ll}0: 00: 00.0 & 0.00 \\ 0: 00: 00.0 & 0.00\end{array}$ $\begin{array}{ll}0: 00: 00.0 & 0.00\end{array}$ 0:00:00.0 $\quad 0.00$ $0: 00: 00.0 \quad 0.00$ 0:00:00.0 $\quad 0.00$ 0:00:00.0 $\quad 0.00$ $0: 00: 00.0 \quad 0.00$ $0: 00: 00.0 \quad 0.00$ 0:00:00.0 $\quad 0.00$ $\begin{array}{ll}0: 00: 00.0 & 0.00 \\ 0: 00: 00.0 & 0.00\end{array}$ $0: 00: 00.0 \quad 0.00$ 0:00:00.0 $\quad 0.00$ $0: 00: 00.0 \quad 0.00$ $0: 00: 00.0 \quad 0.00$ $\begin{array}{ll}0: 00: 00.0 & 0.00 \\ 0: 00: 00.0 & 0.00\end{array}$
$0: 00: 00.0$ $0: 00: 00.0 \quad 0.00$ $0: 00: 00.0 \quad 0.00$ $0: 00: 00.0 \quad 0.00$ $0: 00: 00.0 \quad 0.00$ $0: 00: 00.0 \quad 0.00$ $0: 00: 00.0 \quad 0.00$ 0:00:00.0 $\quad 0.00$ 0:00:00.0 $0: 00: 00.0 \quad 0.00$ $0: 00: 00.0 \quad 0.00$ $0: 00: 00.0 \quad 0.00$ 0:00:00.0 $\quad 0.00$ $0: 00: 00.0 \quad 0.00$ $0: 00: 00.0 \quad 0.00$ $0: 00: 00.0 \quad 0.00$ $0: 00: 00.0 \quad 0.00$ 0:00:00.0 $\quad 0.00$ $0: 00: 00.0 \quad 0.00$ $0: 00: 00.0 \quad 0.00$ $0: 00: 00.0 \quad 0.00$ $0: 00: 00.0 \quad 0.00$ 0:00:00.0 $\quad 0.00$ $0: 00: 00.0 \quad 0.00$ 0:00:00.0 $\quad 0.00$ $0: 00: 00.0 \quad 0.00$ $0: 00: 00.0 \quad 0.00$ $0: 00: 00.0 \quad 0.00$ $0: 00: 00.0 \quad 0.00$ 0:00:00.0 $\quad 0.00$ $0: 00: 00.0 \quad 0.00$ $\begin{array}{ll}0: 00: 00.0 & 0.00 \\ 0: 00: 00.0 & 0.00\end{array}$ 0:00:00.0 $\quad 0.00$ $0: 00: 00.0 \quad 0.00$ 0:00:00.0 $\quad 0.00$ $0: 00: 00.0 \quad 0.00$ $0: 00: 00.0 \quad 0.00$ $0: 00: 00.0 \quad 0.00$ $0: 00: 00.0 \quad 0.00$ $0: 00: 00.0 \quad 0.00$ 0:00:00.0 $\quad 0.00$ $0: 00: 00.0 \quad 0.00$ 0:00:00.0 $\quad 0.00$ $0: 00: 00.0 \quad 0.00$ $0: 00: 00.0 \quad 0.00$ $0: 00: 00.0$ 0:00:00.0 $\quad 0.00$ $0: 00: 00.0 \quad 0.00$ $0: 00: 00.0 \quad 0.00$ 
WELL ID: NTS U-7cd 1

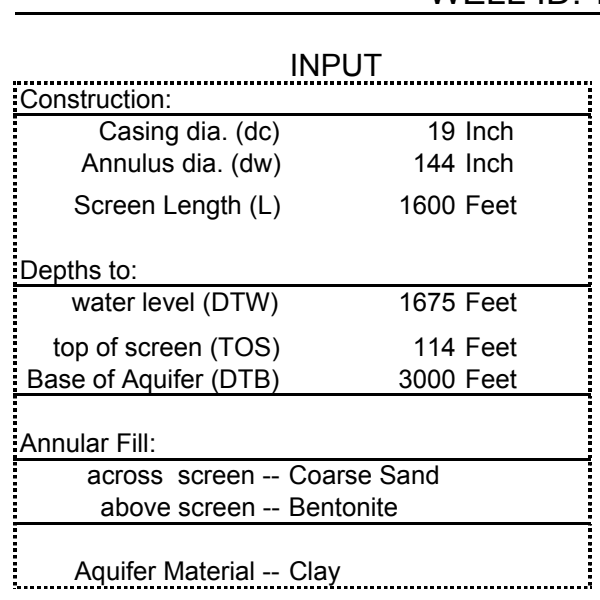

$\begin{array}{rr}\text { Local ID: } & \text { U-7cd } 1 \\ \text { Date: } & 9 / 16 / 1992 \\ \text { Time: } & 14: 39\end{array}$

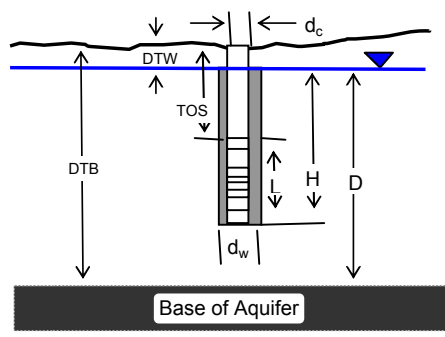

Adjust slope of line to estimate $K$

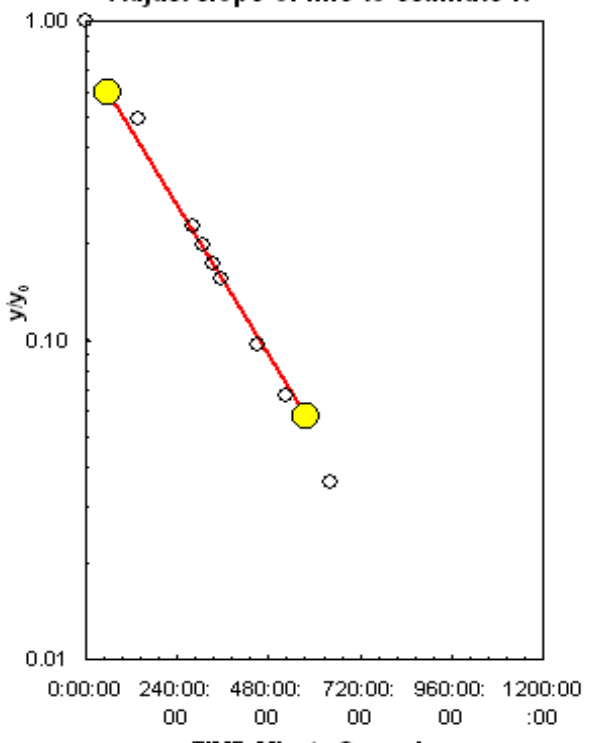

TIME, Minute:Second

$\mathrm{K}=0.0008$ is greater than likely maximum of 0.0001 for Clay

REMARKS:

Bouwer and Rice analysis of slug test, WRR 1976

Reduced Data

Time,

Water

14:39:Sec Level

$14: 39.00 .0 \quad 1675.40$

$\begin{array}{rr}9: 36: 00.0 & 1546.50 \\ 10: 40: 00.0 & 1479.60\end{array}$

$11: 39: 00.0 \quad 1472.50$

$12: 46: 00.0 \quad 1466.50$

$10: 03: 00.0 \quad 1461.80$

$11: 33: 00.0 \quad 1447.00$

9:49:00.0 $\quad 1439.30$

$10: 49: 00.0 \quad 1431.50$

10:04:00.0 $\quad 1424.10$

9.24:00.0 1422.40

0:00:00.0 $\quad 0.00$

$0: 00: 00.0 \quad 0.00$

0:00:00.0 $\quad 0.00$

$0: 00: 00.0 \quad 0.00$

$\begin{array}{ll}0.00: 00.0 & 0.00 \\ 0: 00: 00.0 & 0.00 \\ 0.00 \cdot 0.0 & 0.00\end{array}$

0:00:00.0 $\quad 0.00$

$0: 00: 00.0 \quad 0.00$

0:00:00.0 $\quad 0.00$

$0: 00: 00.0 \quad 0.00$

0.00

$\begin{array}{ll}0: 00: 00.0 & 0.00 \\ 0: 00 \cdot 00.0 & 0.00\end{array}$

$\begin{array}{ll}0: 00: 00.0 & 0.00\end{array}$

$0: 00: 00.0 \quad 0.00$

$0: 00: 00.0 \quad 0.00$

$0: 00: 00.0 \quad 0.00$

$0: 00: 00.0 \quad 0.00$

$0: 00: 00.0 \quad 0.00$

0:00:00.0 $\quad 0.00$

0:00:00.0 $\quad 0.00$

$\begin{array}{ll}0: 00: 00.0 & 0.00 \\ 0: 00: 00.0 & 0.00\end{array}$

$0.00 .00 .0-0.00$

$\begin{array}{ll}0: 00: 00.0 & 0.00\end{array}$

$0.00: 00.0 \quad 0.00$

$\begin{array}{ll}0: 00: 00.0 & 0.00\end{array}$

$0: 00: 00.0 \quad 0.00$

0:00:00.0 $\quad 0.00$

$0: 00: 00.0 \quad 0.00$

$0: 00: 00.0 \quad 0.00$

$0: 00: 00.0 \quad 0.00$

$0: 00: 00.0 \quad 0.00$

$\begin{array}{ll}0: 00: 00.0 & 0.00 \\ 0: 00: 00.0 & 0.00\end{array}$

0.00

$0.00: 00.0 \quad 0.00$

0.00

$\begin{array}{ll}\text { 0:00:00.0 } & 0.00 \\ 0: 00: 00.0 & 0.00\end{array}$
0:00:00.0

0:00:00.0

0:00:00.0

0:00:00.0

$0.00 \cdot 00.0$

$0.00 \cdot 00.0$

0:00:00.0

0:00:00.0

$0: 00: 00.0$

$0: 00.00 .0$

0:00:00.0

0:00:00.0

0:00:00.0

0:00:00.0

$0: 00: 00.0$

$0.00 \cdot 00.0$

0:00:00.0

0:00:00.0

0:00:00.0

0:00:00.0

0:00:00.0

0.00 .00 .0

0:00:00.0

0:00:00.0

0:00:00.0

0:00:00.0

0:00:00.0

0:00:00.0

$0: 00: 00.0$

$0.00: 00.0$

0:00:00.0

0:00:00.0

0:00:00.0

0:00:00.0

$0: 00.00 .0$

0:00:00.0

0:00:00.0

0:00:00.0

0:00:00.0

$0: 00.00 .0$

$0: 00: 00.0$

0:00:00.0

0:00:00.0

0:00:00.0

0:00:00.0

0:00:00.0

0.00 .00 .0

$0: 00: 00.0$

$0.00: 00.0$

$0: 00: 00.0$

0:00:00.0

0:00:00.0
0.00

0.00

0.00

0.00

0.00

0.00

0.00

0.00

0.00

0.00
0.00

0.00

0.00

0.00

0.00

0.00

0.00

0.00

0.00

0.00

0.00
0.00

0.00

0.00

0.00

0.00

0.00

0.00

0.00
0.00

0.00

0.00

0.00

0.00

0.00
0.00

0.00

0.00

0.00

0.00

0.00
0.00

0.00

0.00

0.00

0.00
0.00

0.00
0.00 
WELL ID: NTS UE-4ab-2396

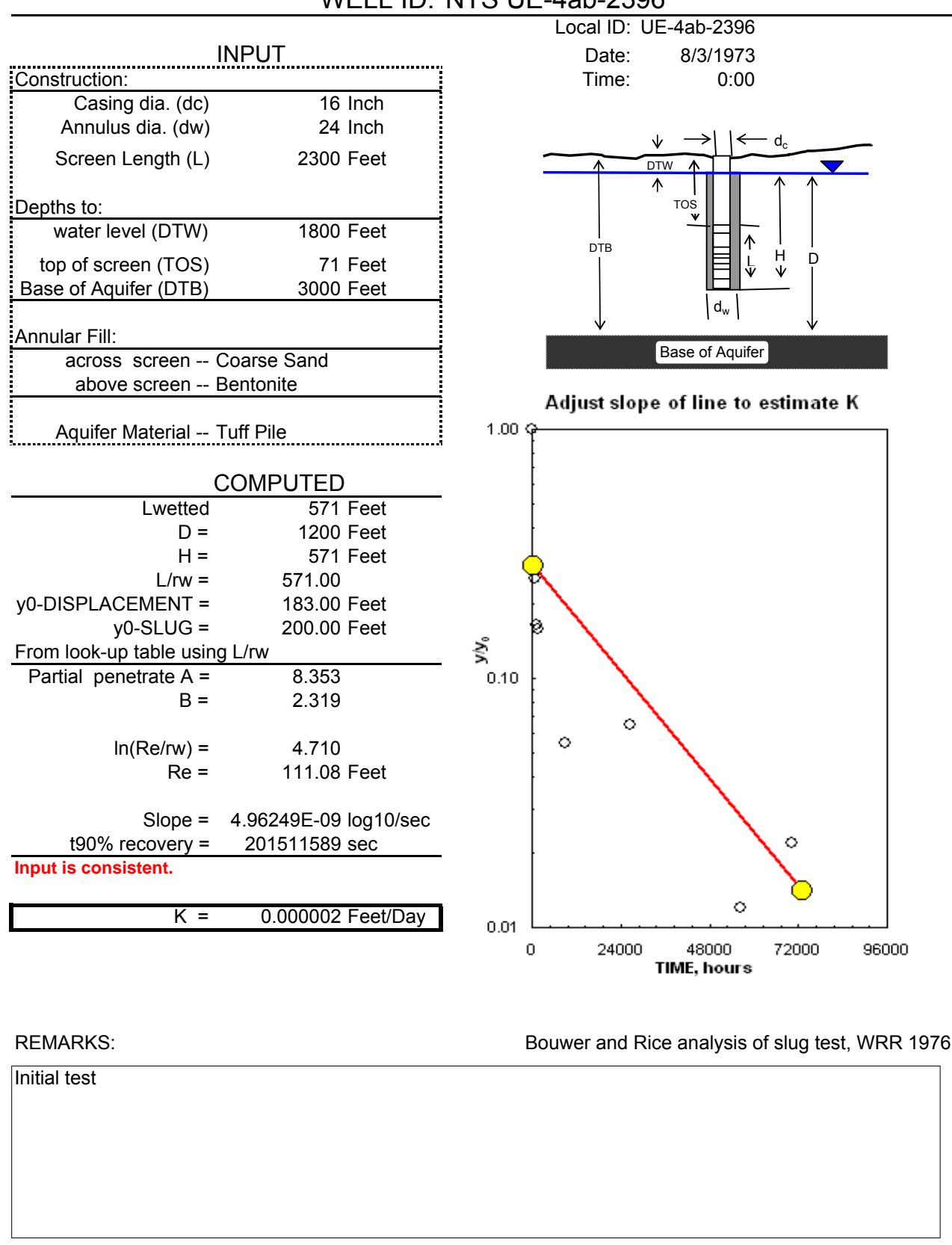

Reduced Data Time, Water Entry Hr:Min:Sec Level

0:00:00.0 $\quad 1807.00$

$0: 00: 00.0 \quad 1670.00$

0:00:00.0 1654.00

0:00:00.0 1653.00

0:00:00.0 1634.00

0:00:00.0 1635.91

$0: 00: 00.0 \quad 1626.20$

0:00:00.0 1628.00

$0: 00: 00.0 \quad 1624.00$

$0.00: 00.0 \quad 0.00$

$0: 00: 00.0 \quad 0.00$

0:00:00.0 $\quad 0.00$

0:00:00.0 $\quad 0.00$

0:00:00.0 $\quad 0.00$

$0: 00: 00.0 \quad 0.00$

$00: 00.0$

$0: 00: 00.0$

0:00:00.0

0:00:00.0

0:00:00.0

$0: 00: 00.0$

$0: 00: 00.0$

0:00:00.0

0:00:00.0

0:00:00.0

0:00:00.0

0:00:00.0

$0: 00: 00.0$

$0: 00: 00.0$

$0: 00: 00.0$

$0: 00: 00.0$

0:00:00.0

0:00:00.0

0:00:00.0

0:00:00.0

0:00:00.0

0:00:00.

0:00:00.0

$0: 00: 00.0$

0:00:00.0

0:00:00:0

0:00:00.0

0:00:00.0

0:00:00.0

0:00:00.0

0:00:00.0

0:00:00.0

0:00:00.0 
WELL ID: NTS UE-4t 1

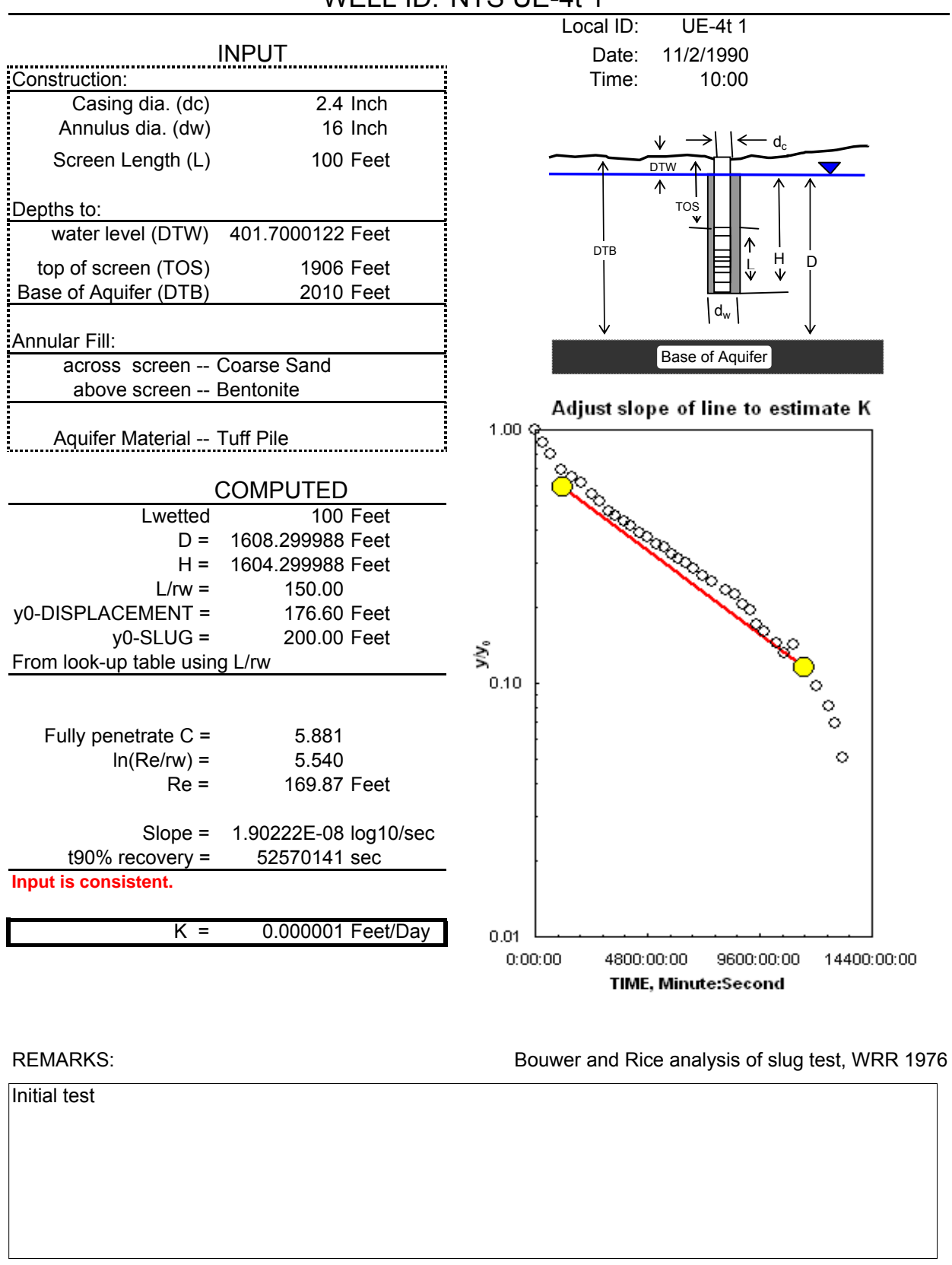

\begin{tabular}{ccc} 
& Reduced Data & \\
& Time & Water \\
Entry & Hr:Min:Sec & \multicolumn{1}{l}{ Level } \\
1 & $10: 00: 00.0$ & 456.60 \\
2 & $9: 20: 00.0$ & 438.00 \\
3 & $11: 35: 00.0$ & 421.20 \\
4 & $9: 55: 00.0$ & 403.10 \\
5 & $12: 55: 00.0$ & 394.29 \\
6 & $9: 30: 00.0$ & 388.60 \\
7 & $11: 19: 00.0$ & 377.90 \\
8 & $10: 54: 00.0$ & 371.90 \\
9 & $10: 40: 00.0$ & 364.60 \\
10 & $10: 35: 00.0$ & 360.70 \\
11 & $11: 05: 00.0$ & 357.10 \\
12 & $11: 20: 00.0$ & 353.70 \\
13 & $12: 05: 00.0$ & 349.19 \\
14 & $10: 37: 00.0$ & 346.40 \\
15 & $11: 38: 00.0$ & 342.50 \\
16 & $11: 23: 00.0$ & 340.60 \\
17 & $7: 42: 00.0$ & 336.71 \\
18 & $10: 34: 00.0$ & 334.90 \\
19 & $12: 55: 00.0$ & 332.49 \\
20 & $12: 28: 00.0$ & 329.79 \\
21 & $10: 40: 00.0$ & 326.80 \\
22 & $11: 18: 00.0$ & 324.40 \\
23 & $9: 58: 00.0$ & 320.90 \\
24 & $9: 53: 00.0$ & 319.70 \\
25 & $10: 52: 00.0$ & 316.20 \\
26 & $11: 20: 00.0$ & 314.10 \\
27 & $12: 52: 00.0$ & 309.99 \\
28 & $11: 22: 00.0$ & 308.20 \\
29 & $11: 15: 00.0$ & 305.30 \\
30 & $11: 16: 00.0$ & 303.20 \\
31 & $12: 44: 00.0$ & 305.19 \\
32 & $11: 45: 00.0$ & 300.89 \\
33 & $10: 27: 00.0$ & 300.00 \\
34 & $11: 09: 00.0$ & 297.20 \\
35 & $10: 54: 00.0$ & 294.40 \\
36 & $10: 39: 00.0$ & 292.20 \\
37 & $10: 30: 00.0$ & 289.00 \\
0 & $0: 00: 00.0$ & 0.00 \\
0 & $0: 00: 00.0$ & 0.00 \\
0 & $0: 00: 00.0$ & 0.00 \\
0 & $0: 00: 00.0$ & 0.00 \\
0 & $0: 00: 00.0$ & 0.00 \\
0 & $0: 00: 00.0$ & 0.00 \\
0 & $0: 00: 00.0$ & 0.00 \\
0 & $0: 00: 00.0$ & 0.00 \\
0 & $0: 00: 00.0$ & 0.00 \\
0 & $0: 00: 00.0$ & 0.00 \\
0 & $0: 00: 00.0$ & 0.00 \\
& $0: 00: 00.0$ & 0.00 \\
\hline & $0: 00: 00.0$ & 0.00 \\
\hline
\end{tabular}

$\begin{array}{ll}0: 00: 00.0 & 0.00 \\ 0: 00: 00.0 & 0.00 \\ 0: 00: 00.0 & 0.00 \\ 0: 00: 00.0 & 0.00 \\ 0: 00: 00.0 & 0.00 \\ 0: 00: 00.0 & 0.00 \\ 0: 00: 00.0 & 0.00 \\ 0: 00: 00.0 & 0.00 \\ 0: 00: 00.0 & 0.00 \\ 0: 00: 00.0 & 0.00 \\ 0: 00: 00.0 & 0.00 \\ 0: 00: 00.0 & 0.00 \\ 0: 00: 00.0 & 0.00 \\ 0: 00: 00.0 & 0.00 \\ 0: 00: 00.0 & 0.00 \\ 0: 00: 00.0 & 0.00 \\ 0: 00: 00.0 & 0.00 \\ 0: 00: 00.0 & 0.00 \\ 0: 00: 00.0 & 0.00 \\ 0: 00: 00.0 & 0.00 \\ 0: 00: 00.0 & 0.00 \\ 0: 00: 00.0 & 0.00 \\ 0: 00: 00.0 & 0.00 \\ 0: 00: 00.0 & 0.00 \\ 0: 00: 00.0 & 0.00 \\ 0: 00: 00.0 & 0.00 \\ 0: 00: 00.0 & 0.00 \\ 0: 00: 00.0 & 0.00 \\ 0: 00: 00.0 & 0.00 \\ 0: 00: 00.0 & 0.00 \\ 0: 00: 00.0 & 0.00 \\ 0: 00: 00.0 & 0.00 \\ 0: 00: 00.0 & 0.00 \\ 0: 00: 00.0 & 0.00 \\ 0: 00: 00.0 & 0.00 \\ 0: 00: 00.0 & 0.00 \\ 0: 00: 00.0 & 0.00 \\ 0: 00: 00.0 & 0.00 \\ 0: 00: 00.0 & 0.00 \\ 0: 00: 00.0 & 0.00 \\ 0: 00: 00.0 & 0.00 \\ 0: 00: 00.0 & 0.00 \\ 0: 00: 00.0 & 0.00 \\ 0: 00: 00.0 & 0.00 \\ 0: 00: 00.0 & 0.00 \\ 0: 00: 00.0 & 0.00 \\ 0: 00: 00.0 & 0.00 \\ 0: 00: 00.0 & 0.00 \\ 0: 00: 00.0 & 0.00 \\ 0: 00: 00.0 & 0.00 \\ 0: 00: 00.0 & \end{array}$


WELL ID: NTS UE-8e-2295

\begin{tabular}{|c|c|}
\hline \multicolumn{2}{|c|}{ INPUT } \\
\hline \multicolumn{2}{|l|}{ Construction: } \\
\hline Casing dia. (dc) & $13.38 \mathrm{Inch}$ \\
\hline Annulus dia. (dw) & 24 Inch \\
\hline Screen Length (L) & 2050 Feet \\
\hline \multicolumn{2}{|l|}{ Depths to: } \\
\hline water level (DTW) & 1900 Feet \\
\hline top of screen (TOS) & 71 Feet \\
\hline Base of Aquifer (DTB) & 3000 Feet \\
\hline \multicolumn{2}{|l|}{ Annular Fill: } \\
\hline \multicolumn{2}{|c|}{$\begin{array}{l}\text { across screen -- Coarse Sand } \\
\text { above screen -- Bentonite }\end{array}$} \\
\hline Aquifer Material & \\
\hline
\end{tabular}

Local ID: UE-8e-2295

Date: $12 / 14 / 1970$

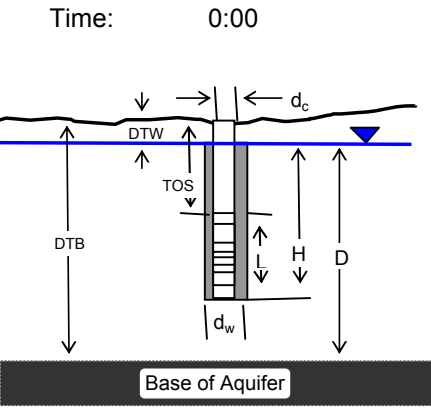

Adjust slope of line to estimate $K$

\begin{tabular}{|c|c|}
\hline \multicolumn{2}{|c|}{ COMPUTED } \\
\hline Lwetted & $221 \mathrm{Feet}$ \\
\hline$D=$ & 1100 Feet \\
\hline $\mathrm{H}=$ & 221 Feet \\
\hline $\mathrm{L} / \mathrm{rw}=$ & 221.00 \\
\hline y0-DISPLACEMENT = & 106.00 Feet \\
\hline y0-SLUG $=$ & 200.00 Feet \\
\hline From look-up table usin & L/rw \\
\hline Partial penetrate $A=$ & 6.433 \\
\hline$B=$ & 1.263 \\
\hline $\ln (\mathrm{Re} / \mathrm{rw})=$ & 3.743 \\
\hline $\mathrm{Re}=$ & 42.22 Feet \\
\hline $\begin{array}{r}\text { Slope }= \\
\text { t90\% recovery }=\end{array}$ & $\begin{array}{l}5.82618 \mathrm{E}-08 \log 10 / \mathrm{sec} \\
17163916 \mathrm{sec}\end{array}$ \\
\hline
\end{tabular}
Input is consistent.

$\mathrm{K}=$

0.00003 Feet/Day

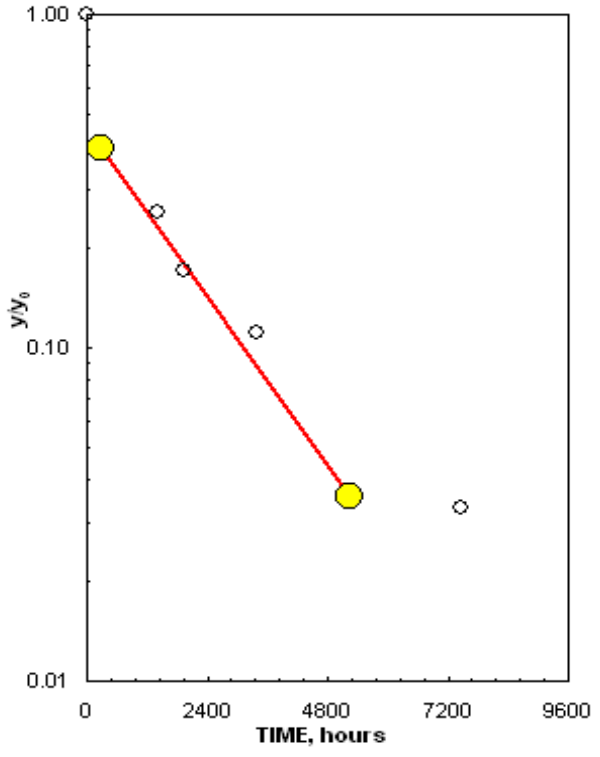

REMARKS:

Bouwer and Rice analysis of slug test, WRR 1976

Initial test

Reduced Data

Time,

Water

Hr:Min:Sec Level

$0: 00.00 .0 \quad 2006.00$

$\begin{array}{ll}0: 00: 00.0 & 1927.00 \\ 0: 00: 00.0 & 1918.00\end{array}$

0:00:00.0 1911.80

$13: 00: 00.0 \quad 1903.50$

$0: 00: 00.0 \quad 0.00$

$0: 00: 00.0 \quad 0.00$

$0: 00: 00.0 \quad 0.00$

$0: 00: 00.0 \quad 0.00$

$0: 00: 00.0 \quad 0.00$

$0: 00: 00.0 \quad 0.00$

$0: 00: 00.0 \quad 0.00$

$0: 00: 00.0 \quad 0.00$

$\begin{array}{ll}0: 00: 00.0 & 0.00 \\ 0: 00: 00.0 & 0.00\end{array}$

0.0000 .00000

$\begin{array}{ll}0.00: 00.0 & 0.00 \\ 0.00: 00.0 & 0.00\end{array}$

$0: 00: 00.0 \quad 0.00$

$0: 00: 00.0 \quad 0.00$

0:00:00.0 $\quad 0.00$

$0: 00: 00.0 \quad 0.00$

$0: 00: 00.0 \quad 0.00$

0:00:00.0 $\quad 0.00$

$\begin{array}{ll}0: 00: 00.0 & 0.00 \\ 0: 00: 00.0 & 0.00\end{array}$

0:00:00.0 $\quad 0.00$

$0: 00: 00.0 \quad 0.00$

$0: 00: 00.0 \quad 0.00$

$0: 00: 00.0 \quad 0.00$

$0: 00: 00.0 \quad 0.00$

$0: 00: 00.0 \quad 0.00$

0:00:00.0 $\quad 0.00$

$0: 00: 00.0 \quad 0.00$

0:00:00.0 $\quad 0.00$

0:00:00.0 $\quad 0.00$

0:00:00.0 $\quad 0.00$

$0: 00: 00.0 \quad 0.00$

0:00:00.0 $\quad 0.00$

0:00:00.0 $\quad 0.00$

$0: 00: 00.0 \quad 0.00$

$0: 00: 00.0 \quad 0.00$

0:00:00.0 $\quad 0.00$

$\begin{array}{ll}0: 00: 00.0 & 0.00 \\ 0: 00: 00.0 & 0.00\end{array}$

0:00:00.0 $\quad 0.00$

0:00:00.0 $\quad 0.00$

0:00:00.0 $\quad 0.00$

$\begin{array}{ll}0: 00: 00.0 & 0.00\end{array}$

$0: 00: 00.0$

0:00:00.0

0.00
0.00
0:00:00.0

0:00:00.0

0:00:00.0

0:00:00.0

$0: 00: 00.0$

$0.00 \cdot 00.0$

0:00:00.0

0:00:00.0

$0: 00: 00.0$

$0: 00.00 .0$

0:00:00.0

0:00:00.0

0:00:00.0

$0: 00: 00.0$

$0: 00: 00.0$

0:00:00.0

$0: 00: 00.0$

0:00:00.0

0:00:00.0

0:00:00.0

$0: 00: 00.0$

$0: 00: 00.0$

0:00:00.0

0:00:00.0

0:00:00.0

0:00:00.0

0:00:00.0

0:00:00.0

$0: 00: 00.0$

$0.00: 00.0$

0:00:00.0

0:00:00.0

0:00:00.0

0:00:00.0

$0: 00.00 .0$

0:00:00.0

0:00:00.0

0:00:00.0

0:00:00.0

$0: 00.00 .0$

$0: 00: 00.0$

0:00:00.0

0:00:00.0

0:00:00.0

0:00:00.0

0.00 .00 .0

$0: 00: 00.0$

$0.00: 00.0$

$0: 00: 00.0$

0:00:00.0

0:00:00.0
0.00

0.00

.00

000

0.00

0.00

0.00

0.00

0.00

0.00
0.00

0.00

0.00

0.00

0.00

0.00

0.00

0.00

0.00

0.00

0.00
0.00

0.00

0.00

0.00

0.00

0.00

0.00

0.00
0.00

0.00

0.00

0.00

0.00

0.00

0.00
0.00

0.00

0.00

0.00

0.00
0.00

0.00

0.00

0.00

0.00

0.00

0.00
0.00 